

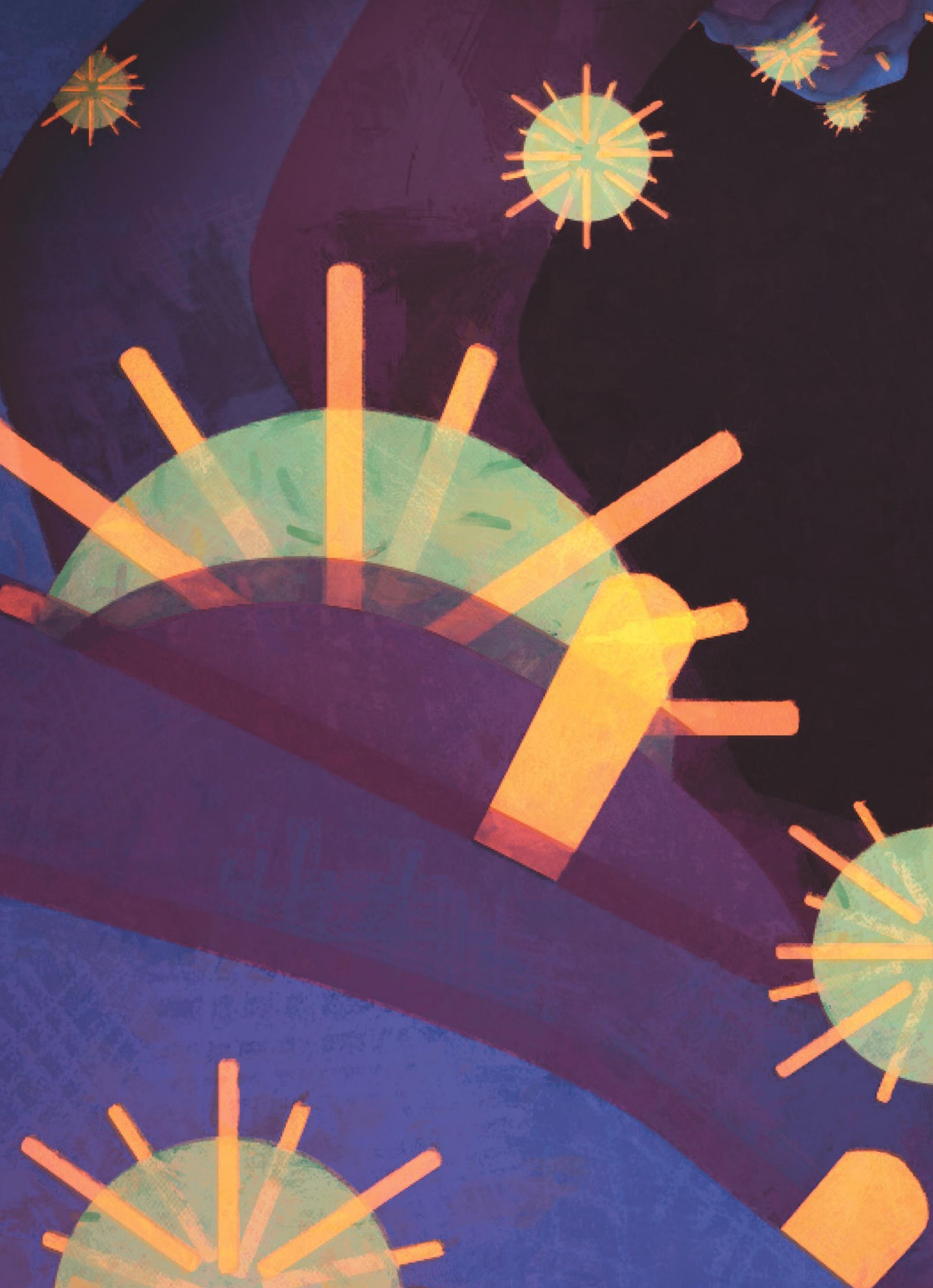



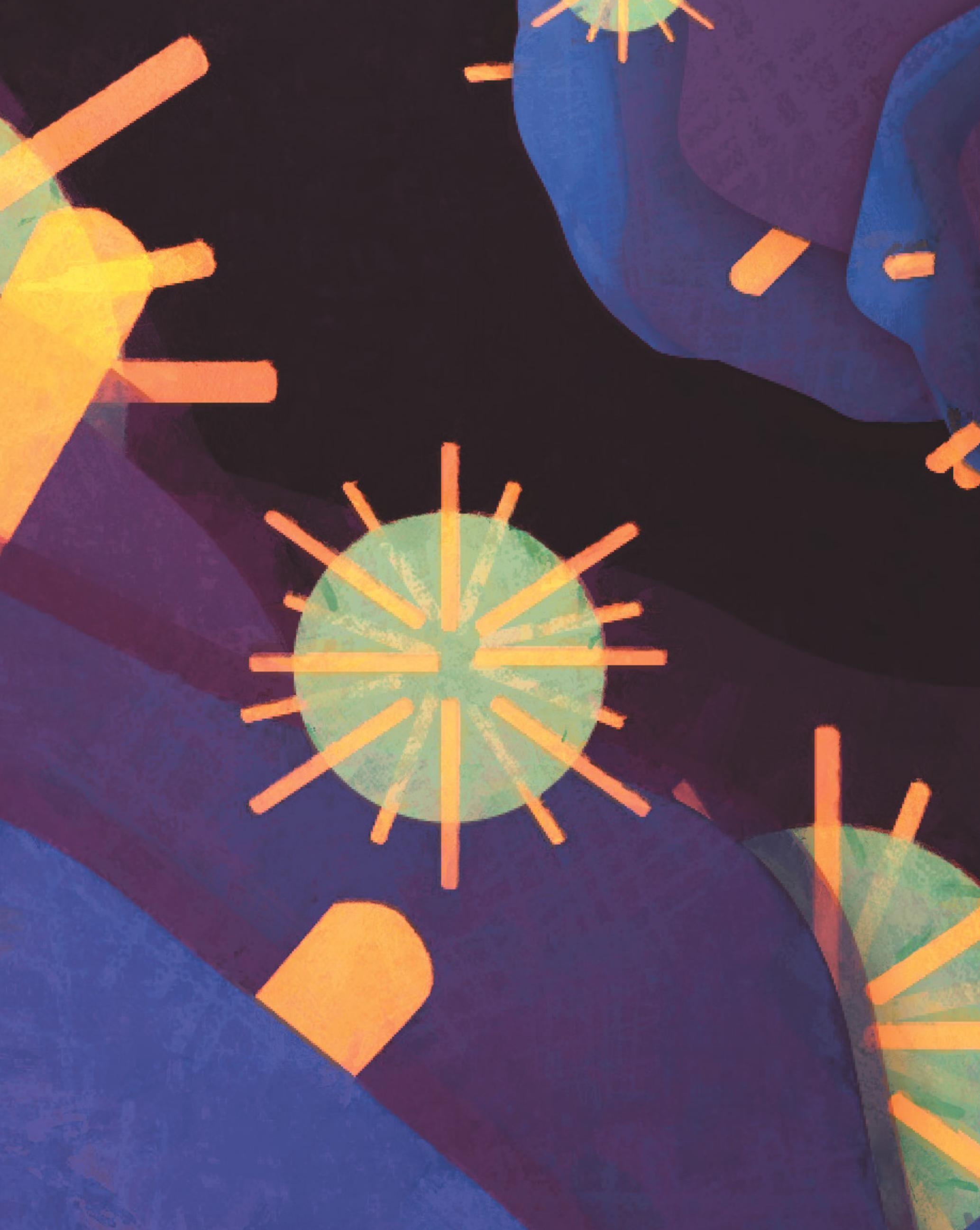




\begin{abstract}
Universidad Autónoma de Madrid
Programa de Doctorado en Biociencias Moleculares
\end{abstract}

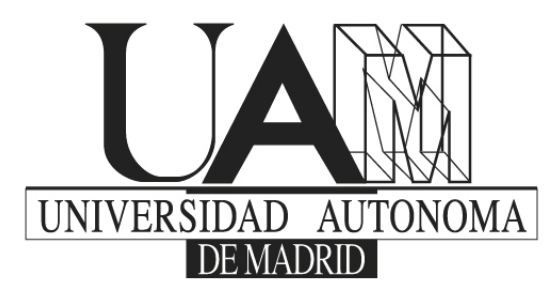

Polybacterial mucosal vaccine protects against viral respiratory infections and induces trained immunity

\author{
Paola Brandi \\ Licenciada en Biotecnologia Medica
}

Madrid, 2019 

Departamento de Bioquímica

Facultad de Medicina

Universidad Autónoma de Madrid.

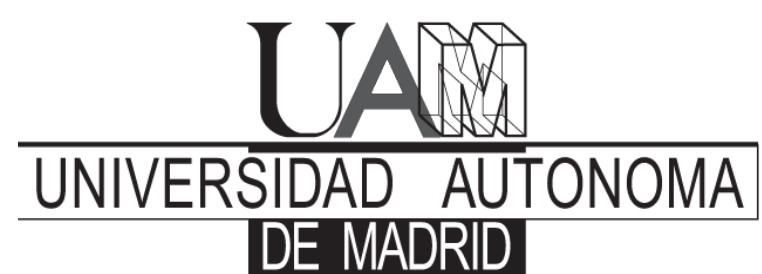

\section{Polybacterial mucosal vaccine protects against viral respiratory infections and induces trained immunity}

Paola Brandi

Licenciada en Biotecnologia Medica

Tesis doctoral dirigida por:

Dr. David Sancho Madrid

Esta tesis se ha desarrollado en el

Centro Nacional de Investigaciones Cardiovasculares.

Madrid, 2019 

El Doctor David Sancho Madrid, lider del grupo de investigacion "Inmunobiologia" de la Fundacion-Centro Nacional de Investigaciones Cardiovasculares Carlos III (CNIC),

\section{CERTIFICA:}

que Paola Brandi Licenciada en Biotecnologia Medica y Master en Biomedicina Molecular, titulaciones obtenidas por la Universidad Federico II di Napoli y Universidad Autonoma de Madrid, resepctivamente, ha realizado bajo su supervision el trabajo de Tesis Doctoral: Polybacterial mucosal vaccine protects against viral respiratory infections and induces trained immunity.

Para la realizacion de esta Tesis Doctoral se contó con la financiacion de: Ayudas para Contratos Predoctorales para la Formación de Doctores 2014 ( Referencia: BES-2014-069933), del Consejo Europeo de Investigacion (ERC-2010-StG 260414), de la Fundacion ACTERIA y del Ministerio de Economia y Competitividad (SAF2010-15120,SAF2013-42920R y SAF2016-79040-R).

Revisado el presente trabajo, expresa su conformidad para la presentación del mismo en el Departamento de Bioquímica de la Universidad Autónoma de Madrid, por considerar que reúne los requisitos necesarios para ser sometido a su evaluación ante el tribunal correspondiente para optar al grado de Doctor en Biociencias Moleculares por la Universidad Autónoma de Madrid.

Y para que así conste y a los efectos oportunos, firma el presente certificado en Madrid, a 18 de octubre de 2019.

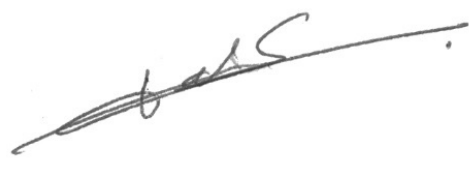

Dr. David Sancho Madrid Investigador Principal, CNIC Director de tesis 

Ai miei genitori e a mio fratello A Ricardo 

"I do not know what I may appear to the world, but to myself I seem to have been only like a boy playing on the seashore, and diverting myself in now and then finding a smoother pebble or a prettier shell than ordinary, whilst the great ocean of truth lay all undiscovered before me." 



\section{Index}

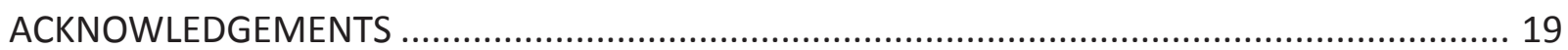

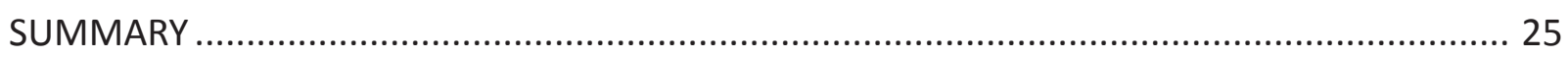

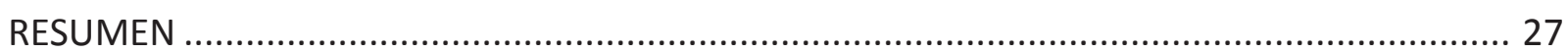

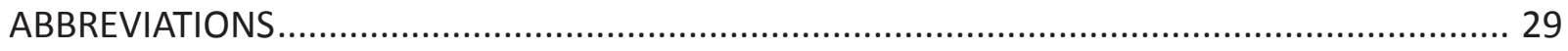

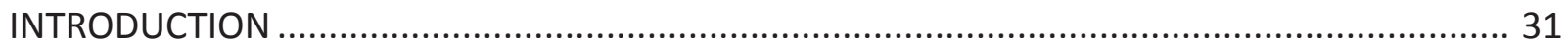

1. The immune system: a complex network of different players ..................................... 33

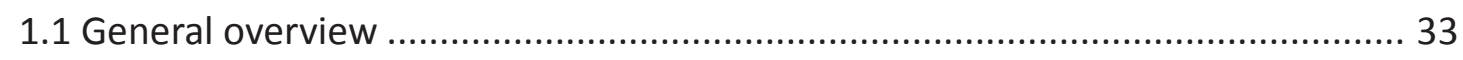

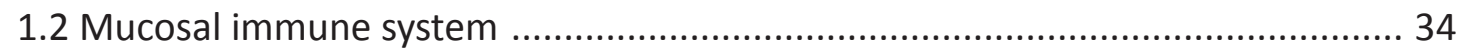

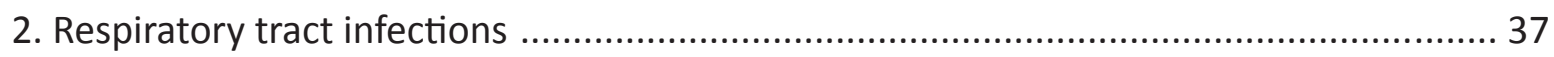

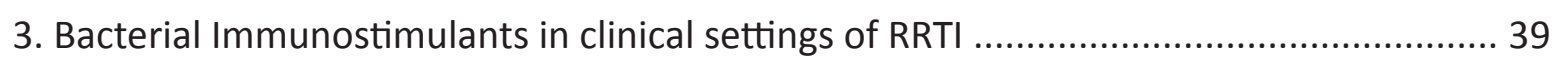

3.1 The polybacterial mucosal vaccine MV130 .................................................... 40

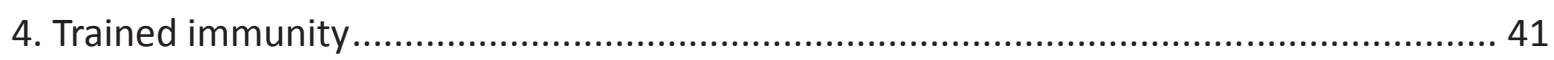

4.1 The origins of the "innate immune memory" theory........................................ 41

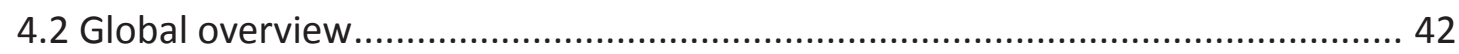

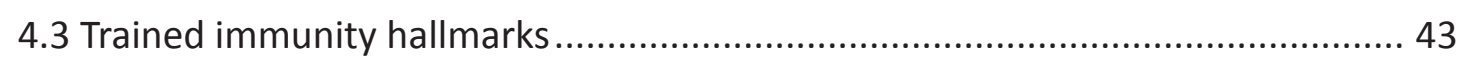

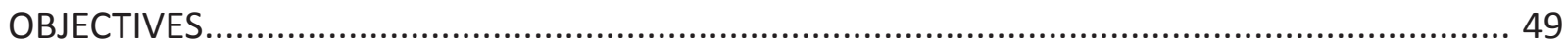

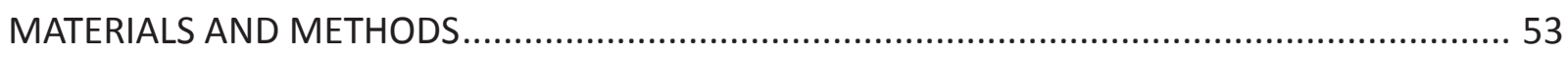

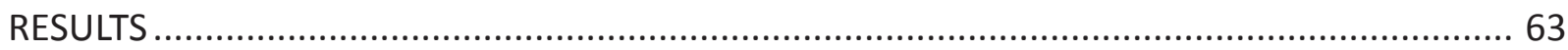

1. Role of MV130 in the protection against viral respiratory infections ............................ 65

$1.1 \mathrm{MV} 130$ protects against Vaccinia virus respiratory infection in mice....................66

1.2 Intranasal vaccination with MV130 results in reduced VACV viral load

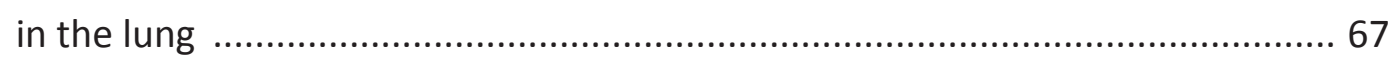

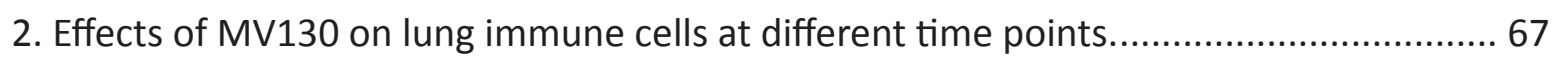

$2.1 \mathrm{MV} 130$ affects the expansion of both myeloid and lymphoid populations.......... 67 


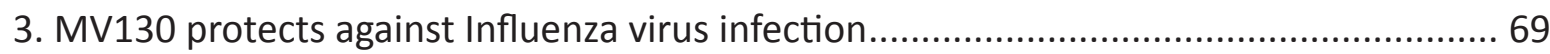

3.1 The role of MV130 against Influenza virus infection. ...................................... 69

4. MV130 provides systemic protection against Candida albicans infection by a mechanism that does not depend on adaptive immunity. ........................................ 70

4.1 Mice intranasally challenged with MV130 are protected against systemic Candida albicans infection.

4.2 MV130-mediated protection against systemic $C$. albicans infection in mice is not dependent on adaptive immune system.

5. MV130 educates myeloid progenitors promoting their differentiation into trained mature cells.

5.1 Bone marrow derived macrophages from mice treated in vivo with MV130 show higher TNF $\alpha$ production in response to LPS.

6. mTOR pathway involvement in the MV130-mediated protection

6.1 Metformin treatment significantly reduces MV130-mediated protection against Influenza virus respiratory infection.

7. MV130 trains human monocytes in vitro 75

7.1 MV130 promotes increased cytokine production by human monocytes in vitro and its effect relies on epigenetic changes.

7.2 MV130 promotes increased lactate production in supernatants from human monocytes

DISCUSSION 79

1. MV130 protects against viral respiratory infections 83

2. MV130 presents immunomodulatory abilities in the lung compartment 84

3. MV130 mediated protection correlates with trained immunity induction 85

4. MV130 in humans: a trained-immunity based vaccine 88 CONCLUSIONS. 91

CONCLUSIONES . 95

BIBLIOGRAPHY. 99

APPENDIX 

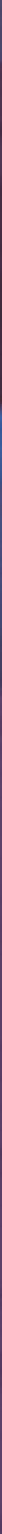



\section{Acknowledgements}

todos los que me han acompañado en este camino: Gracias a David, por darme la
oportunidad de desarrollar mi tesis doctoral en su laboratorio. Gracias por confiar en
mi, por apoyarme cuando lo he necesitado, por dejar la puerta de tu despacho siempre abierta y responder siempre "si" a mi "David tienes un minuto?" aun sabiendo que nunca era un minuto. Gracias por haberme siempre dado la posibilidad de un confronto, escuchando mis puntos de vista e intentando hacerme ver las cosas de otros ángulos.

Gracias a Fran y Sarai, por estar conmigo desde el minuto cero sin dejarme caer nunca, porque esta tesis sin vostros no habria sido la misma. Todos deberían tener la suerte de encontrar compañeros de trabajo y amigos como vostros! Sarai gracias por tu entusiasmo en enseñar y en aprender, por tu ilusión, tu compromiso, por nuestras risas, por organizar experimentos conmigo rescatándome de mi desorden. Gracias por llevarme de prisa al muelle en momentos de panico, por haber sido mi brazo derecho en el trabajo y sobretodo por ser mi amiga en el día día. Fran no es fácil resumir en pocas rigas tantos años de amistad y de tesis juntos... asi que empezaré dándote las gracias por proponerme estudiar juntos aquel día en el master, porque asi es como todo este camino empezò. Gracias por tu buen humor y tu ironía que han sido los pilares de mis días en el laboratorio, por tus curiosidades e intereses tanto en la ciencia como en la vida, por dejarme la puerta de tu casa siempre abierta, por tus moralejas aunque no sepas contarlas, por haberme interamente spoilerado "the office", por haberme enseñado a hablar "granaino" y simplemente por estar siempre!

Gracias a todos los compañeros del labo porque de cada uno de vostros me llevo algo. Gracias a Michel por nuestras infinitas conversaciones de las que siempre salía aprendiendo algo, a Car- 
los por nuestras colaboraciones, por sus consejos cientificos, por su buen humor, por los "Viernes de cerveza" y por su abertura a la escucha, a Paula tanto por los momentos bonitos como por las situaciones dificiles que hemos compartido juntas, a Laura por los teatros, los conciertos y los viajes que hemos disfrutado juntas, por haberme dejado en herencia este proyecto de tesis y "algún falcón ya rotulado, por si acaso..." A Sofia por tus críticas costrutivas, por enseñarme a ver las cosas de otra perspectiva, por nuestras conversaciones siempre enrequecidoras. A Ruth por tu amabilidad y disponilidad costantes, a Salva por tus bromas que alegran los días y por darme sugerencias cientificas siempre que las he necesitado, a María por nuestras disertaciones filosóficas y psicológicas a ultima hora del dia, a Elenita por tus consejos fitness y por tu ser tan solar, a Joaquín por tus bromas que aunque malas te sacan siempre una sonrisa y por el mega regalo que me hiciste "Drones, Black holes and Revelations, The resistance"... bueno creo nos hemos entendido. A Annalaura perché sei entrata nella mia vita in punta di piedi e hai portato tanta serenità e allegria, per i nostri caffè, per i tuoi consigli, per essere la dimostrazione vivente che "la calma è la vitu' dei forti" ! A Gillian tanks for being always so lovable, for your brightness and for your wonderful smile that every morning "energises me"! Gracias a Nacho por compartir conmigo tus visiones diferentes de la vida, a Steffi for being the live evidence that no matter the number of coffees taken in one day, humans can survive, a Dieke for our interesting discussions about films and actors and life-moments, y gracias a todos los que han pasado por aqui dejando una huellita, en particular a Carmen y Juan Fran, por haber sido mis pequeños estudiantes.

Gracias a Andrés Hidalgo por tu cercanía, por haber sido el primero a creer en mi, por motivarme, por enseñarme que en ciencia todas las preguntas son posibles y por recordarme siempre que "no hay experimentos malos ni buenos, solo experimentos con buenos controles!" Gracias a todo tu grupo de aquel tiempo en particular a Noelia por estar siempre que lo haya necesitado, tanto en el labo como en la vida, a Juan por nuestras risas, a María por tu disponibilidad, interes en la ciencia y tu genuinidad, a Geo por tu fuerza y determinación, a Jose por tu grande honestidad tanto intelectual como en la vida y sobretodo a Ángel mi pequeño grande gallego, por tu amistad, tu comprensión, por nuestras charlas y por nuestras risas! Por seguir vigilándome de lejos asegurándote de que todo vaya bien.

Gracias a Vicente Andrés por haberme dado la oportunidad de entrar en el CNIC y también a todo tu grupo de aquel tiempo. A Pedro por haber sido mi tutor en la instancia, a María Jesús por ser "tan madre" con todos los miembros del grupo, a Rafa por tu apoyo y tu ayuda incondicional 
y a Javi, por nuestras tardes de gimnasio, nuestras comidas los domingos y sobretodo por haber cuidado de mi un intero año!

Gracias a toda la gente del animalario y en particolar a Juanjo, Iván y Antonio, por haberme facilitado siempre la vida, por nuestras charlas divertidas, por ayudarme a buscar algun ratoncito escapista, todo siempre con una mega sonrisa! Gracias a toda la unidad de citometría por estar siempre alli para todo. Gracias a Laura Grau y Almudena por vuestra paciencia y afabilidad ayudandome en todos los asuntos de papeleo posibles! Gracias a María Ángeles (Mari) por tu capacidad organizativa y de gestión porque contigo todo está impecable y bajo control. Gracias al personal de la cafetería y en particolar a Ángel, por tu sentido del umor, por mi "cafe-Pao" con espumita, por ralegrarme los días malos con sonsrisas y chocolate! Gracias a Petri por tu cariño, por preguntarme siempre: "cómo vamos nena?", por los abrazos que me has reservado en todos estos años.

Gracias a todas las personas que me han regalado una sonrisa o que simplemente han compartido conmigo un trocito de su día... en particular gracias a Toñi y Ana Paredes, por vuestra energia positiva, por vuestros consejos y por todas las charlas de última hora. Gracias a todos los colaboradores, en particular a Irene, por enseñarme con paciencia y amabilidad a cortar y teñir cerebros. Gracias a Manuel de bioinformática por tu disponibilidad y tu actitud siempre afable.

Gracias a Juanma, mi ilustrador favorido, por tu gran trabajo, por tu creatividad y por tu paciencia! Espero no haberte puesto la "testa como un bombo"!

Gracias a mis amigas del teatro, Sandra, Olalla y Laura, por nuestros fantásticos viajes, nuestros espectáculos teatrales, los días del arte, de comida, de yoga y nuestras conversaciones sobre el universo, la naturaleza, las mujeres y el amor.

Grazie a Davide, Genny e Mauro... siete la mia famiglia Madrilena, il mio hogar, il luogo in cui posso essere me stessa. Mauro grazie per tutti i momenti che abbiamo condiviso soprattutto nel nostro anno di convivenza, le cene con la chitarra, le corse al retiro, i video suonando e cantando, le conversazioni profonde e strambe! Grazie perchè in ogni momento importante ci sei stato e so che continuerai a farlo. Genny grazie per esserci sempre e per la tua instancabile allegria e per il tuo ottimismo. La prima volta che andai via da Madrid mi dicesti: "che piangi a fare??? Tanto ci vediamo!" Io non ti credevo e invece era proprio cosi... e ad oggi, anche a distanza, sei sempre il mio porto sicuro. Davi grazie per avermi lasciato entrare, non proprio in punta di piedi, nella tua 
vita. Grazie perché da sempre ti prendi cura di me, perchè quando ti chiamo non importa che ore sono, dove sei, che programmi hai, tu semplicemente ci sei. Grazie perché molto spesso anche senza parlare tu sai già come sto e di cosa ho bisogno e prima di poterti chiedere qualcosa tu hai già fatto tutto.

Grazie a tutte le mie amiche italiane! Fede C, Elvy, Vale, Fede U, Conny, Isabella, Lucia d.S., Raffaella... grazie perché insieme abbiamo superato le distanze. Grazie per tutti i momenti condivisi, per la fiducia che mi date, grazie per aver sempre creduto in me spingendomi a dare il meglio anche quando non pensavo di farcela.

Grazie a tutta la mia famiglia per essere sempre a mio lato e per farmi sentire che nonostante gli anni e gli eventi ci sono affetti che non cambiano mai. Un grazie speciale va a mia nonna Anna P. per avermi donato tutto il suo amore, per avermi sempre fatto sentire speciale, per avermi insegnato che per raggiungere un obiettivo bisogna dedicare "anima e corpo", si, perché con la testa e con il cuore non c'è muro che non si possa superare.

Gracias a mi pequeña Shiva, por los paseos en la naturaleza, por enseñarme que no importa cuanto tiempo haya pasado, si alguien que amamos vuelve siempre es una fiesta! Por nuestros mimos en el sofá, por enseñarme que en esta vida todo es una sorpresa, una hoja que cae, el ruido del viento, un perfume en el aire... que muchas veces la realidad esta en los ojos de quien mira y así un charco puede transformarse en una piscina.

Gracias a Ana, Miguel y Miguelito por haberme acogido en su familia, por las comidas de los domingos, por cuidar de Shiva cuando "vamos a lo loco" y por estar siempre a nuestro lado. Il grazie più importante va a chi ha reso possibile tutto questo.

Gracias a Ricardo, por hacer reales todos mi sueños. Gracias por tu amor incondicionado, por aguantar mis peores dias, por tu apoyo incansable, por buscar "siempre soluciones y nunca problemas". Gracias por estar siempre a mi lado, por ayudarme a superar mis miedos y mis limites. Gracias por creer en mi y por iluminar mis dias con tu sonrisa.

Grazie a mio fratello Claudio, per la tua presenza oltre la distanza, per il tuo buon umore, per la tua ironia, per la tua forza smisurata! Grazie per avermi fatto sempre sentire che dentro di te c'è una parte importante di me, per avermi sempre fatto vedere il lato pratico delle cose, per esserti comportato a volte da fratello maggiore pur essendo tu il piccolo della casa. Grazie ai miei genitori perché è a loro che devo tutto. Loro sono i miei eroi, i miei lottatori instancabili. Babbo 
grazie per avermi insegnato a sognare, a credere nei miei sogni e a lottare per raggiungerli. Tu mi hai insegnato l'arte dell'avventura, mi hai mostrato che abbiamo ali grandi per volare e che è necessario solo volerlo. Mami tu rappresenti le fondamenta della nostra famiglia. Con la tua forza e la tua determinazione ci hai sempre sostenuti. Grazie per avermi insegnato a non temere gli ostacoli, a pensare prima di agire, a non aver paura di cadere perché c'è sempre un modo per rialzarsi e a cercare di raggiungere i miei obiettivi sempre restando me stessa e senza mai perdere i miei valori. 



\section{Summary}

$\mathrm{R}$ ecurrent respiratory tract infections (RRTI) are very frequent in childhood due to the immature state of the immune system and the traditional therapeutic strategies just rely on antibiotic treatments. However, the etiology of RRTIs is diverse, with viruses being the most common cause of the disease. Thus, alternative approaches that tackle this health issue are needed. In this direction, several studies have shown that bacterial preparations provide protection against RRTI through the modulation of both cellular and humoral responses. MV130 is a sublingual preparation of different whole inactivated bacteria that are frequently present in the human respiratory tract. Its efficacy against RRTIs has been already demonstrated both in adults and in children, but its mechanism of action remains unexplored. Herein, we observed that MV130 treatment in mice provided protection against both Vaccinia and Influenza A respiratory infections and this was reflected into less weight loss and better survival than control mice. Indeed, MV130-treated mice showed a reduced viral load in the lungs at day three post infection. Moreover, MV130 treatment causes a general infiltration of both myeloid and lymphoid cell populations in the lungs. Several studies indicate that certain microbial stimuli can induce functional, metabolic and epigenetic changes in innate immune cells resulting in long-lasting improved response to a secondary infection. This phenomenon is termed trained immunity. Therefore, we hypothesized that MV130 could confer protection by inducing trained immunity. We observed that MV130 provides protection to mice against systemic Candida albicans infection, a benchmark in vivo model of trained immunity. Moreover, the protective effect of MV130 was reproduced in mice that lack $\mathrm{T}$ and $\mathrm{B}$ lymphocytes. Following metformin treatment, which inhibits the mTOR pathway and thus impairs trained immunity, mice pretreated with MV130 lost the protection against Influenza A respiratory infection. MV130 is also able to educate myeloid progenitors, which can give rise in vitro to trained mature cells. Finally, we found that MV130 is able to induce trained immunity in human monocytes, promoting metabolic and epigenetic modulation and enhanced cytokine production. Thus, these results highlight the important role of MV130 mediated-cross protection through generation of innate immune memory. 



\section{Resumen}

L as infecciones recurrentes del tracto respiratorio (IRTR) son muy frecuentes en la infancia debido al estado inmaduro del sistema inmune y las únicas estrategias terapéuticas dispo-

nibles se basan en la antibioterapia. Sin embargo, la etiología de los IRTR es diversa, siendo los virus la causa más común de la enfermedad. Por lo tanto, se necesitan enfoques alternativos que aborden este problema de salud. En esta dirección, varios estudios han demostrado que las preparaciones bacterianas proporcionan protección contra IRTR a través de la modulación de las respuestas tanto celulares como humorales. MV130 es una preparación sublingual de diferentes bacterias inactivadas enteras, que con frecuencia están presentes en el tracto respiratorio humano. Su eficacia contra las IRTR ya se ha demostrado tanto en adultos como en niños, pero su mecanismo de acción permanece sin explorar. Aquí, observamos que el tratamiento MV130 en ratones proporcionó protección contra las infecciones respiratorias de Vaccinia e Influenza A y esto se reflejó en una menor pérdida de peso y una mejor supervivencia que los ratones control. De hecho, los ratones tratados con MV130 mostraron una carga viral reducida en los pulmones tres días después de la infección. Además, el tratamiento con MV130 provoca una infiltración general de las poblaciones celulares mieloides y linfoides en los pulmones.

Varios estudios indican que ciertos estímulos microbianos pueden inducir cambios funcionales, metabólicos y epigenéticos en las células inmunes innatas, que resultan en una respuesta mejorada y duradera a una infección secundaria. Este fenómeno se denomina inmunidad entrenada. Por lo tanto, planteamos la hipótesis de que MV130 podría conferir protección al inducir inmunidad entrenada. Observamos que MV130 proporciona protección a los ratones contra la infección sistémica por Candida albicans, un modelo de referencia in vivo de inmunidad entrenada. Además, el efecto protector de MV130 se reprodujo en ratones que carecen de linfocitos T y B. Al tratar con metformina, que inhibe la vía mTOR y, por lo tanto, impide la inmunidad entrenada, los ratones pretratados con MV130 perdieron la protección contra la infección respiratoria por Influenza A. MV130 también puede educar a los progenitores mieloides, que pueden dar lugar in vitro a células maduras entrenadas. Finalmente, descubrimos que MV130 es capaz de inducir inmunidad entrenada en monocitos humanos, promoviendo la modulación metabólica y epigenética y una mayor producción de citocinas. Por lo tanto, estos resultados destacan el importante papel de la protección cruzada mediada por MV130 a través de la generación de memoria inmune innata. 



\section{Abbreviations}

$\begin{array}{ll}\text { AKT } & \text { Protein kinase B } \\ \text { AMPK } & \text { AMP-activated protein kinase } \\ \text { APC } & \text { Antigen Presenting Cell } \\ \text { ARDS } & \text { Acute respiratory distress syndrome } \\ \text { BCG } & \text { Bacillus Calmette-Guérin } \\ \text { BMDM } & \text { Bone marrow derived macrophages } \\ \text { CCL } & \text { Chemokine (C-C motif) ligand } \\ \text { CLR } & \text { C-type lectin receptor } \\ \text { DAMP } & \text { Damage-associated molecular pattern } \\ \text { DC } & \text { Dendritic cells } \\ \text { EDTA } & \text { Ethylene diamine tetra acetate } \\ \text { EGCG } & \text { Epigallocatechin-3-gallate } \\ \text { ELISA } & \text { Enzyme-linked immunosorbent assay } \\ \text { EpSC } & \text { Epithelial stem cells } \\ \text { FACS } & \text { Fluorescence-activated cell sorting } \\ \text { FBS } & \text { Fetal bovine serum } \\ \text { GMP } & \text { Granulocyte-macrophage progenitor } \\ \text { H3K27Ac } & \text { Acetylation in lysine 27 of histone H3 } \\ \text { H3K4me1 } & \text { Monomethylation in lysine } 4 \text { of histone H3 } \\ \text { H3K4me3 } & \text { Trimethylation in lysine } 4 \text { of histone H3 } \\ \text { HIF1 } \alpha & \text { Hypoxia Inducible Factor 1 } \alpha \\ \text { hmoDC } & \text { Human monocyte derived DC } \\ \text { hPBMC } & \text { Human peripheral blood mononuclear cell } \\ \text { HSC } & \text { Intranasal } \\ \text { i.n. } & \text { Intravenous } \\ \text { i.v. } & \end{array}$




\begin{tabular}{|c|c|}
\hline IFN & Interferon \\
\hline $\lg$ & Immunoglobulin \\
\hline IGF1R & Insulin-like growth factor 1 receptor \\
\hline IL & Interleukin \\
\hline LPS & Lipopolysaccharide \\
\hline MALT & Mucosa associated lymphoid tissue \\
\hline $\mathrm{M}$ cells & Microfold cells \\
\hline MPP & Multipotent progenitor \\
\hline MTA & 5'-deoxy-5'-(methylthio)adenosine \\
\hline mTOR & Mammalian target of rapamycin \\
\hline NALT & Nasopharynx-associated lymphoid tissue \\
\hline NK & Natural Killer \\
\hline NLRP & NOD-like receptor \\
\hline NOD & Nucleotide-binding oligomerization domain \\
\hline oxLDL & Oxidized low-density lipoprotein \\
\hline p.i. & post infection \\
\hline PAMP & Pathogen associated molecular pattern \\
\hline PBMC & Peripheral blood mononuclear cell \\
\hline PBS & Phosphate buffered saline \\
\hline pDC & Plasmacytoid dendritic cells \\
\hline PPs & Peyer's patches \\
\hline PRR & Pattern recognition receptors \\
\hline RPM & Revolutions per minute \\
\hline RPMI & Roswell Park Memorial Institute \\
\hline RRTI & Recurrent respiratory tract infections \\
\hline RSV & Respiratory Syncytial virus \\
\hline RT & Room temperature \\
\hline RTI & Respiratory tract infections \\
\hline RV & Rhinovirus \\
\hline s.l. & Sublingual \\
\hline S1P & Sphingosine-1-phosphate \\
\hline SAR & Systemic acquired resistance \\
\hline TCA & Tricarboxylic acid cycle \\
\hline TIbV & Trained immunity-based vaccine \\
\hline TLR & Toll-like receptor \\
\hline TNF $\alpha$ & Tumor necrosis factor $\alpha$ \\
\hline Tregs & T regulatory cells \\
\hline VACV & Vaccinia virus \\
\hline WA & Wheezing attacks \\
\hline WT & Wild-type \\
\hline YPD & Yeast extract-peptone-dextrose \\
\hline
\end{tabular}


INTRODUCTION 


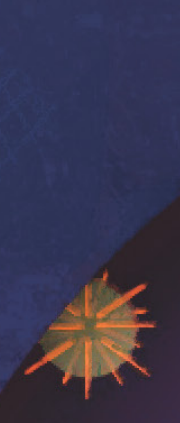

$$
\text { (1) }
$$
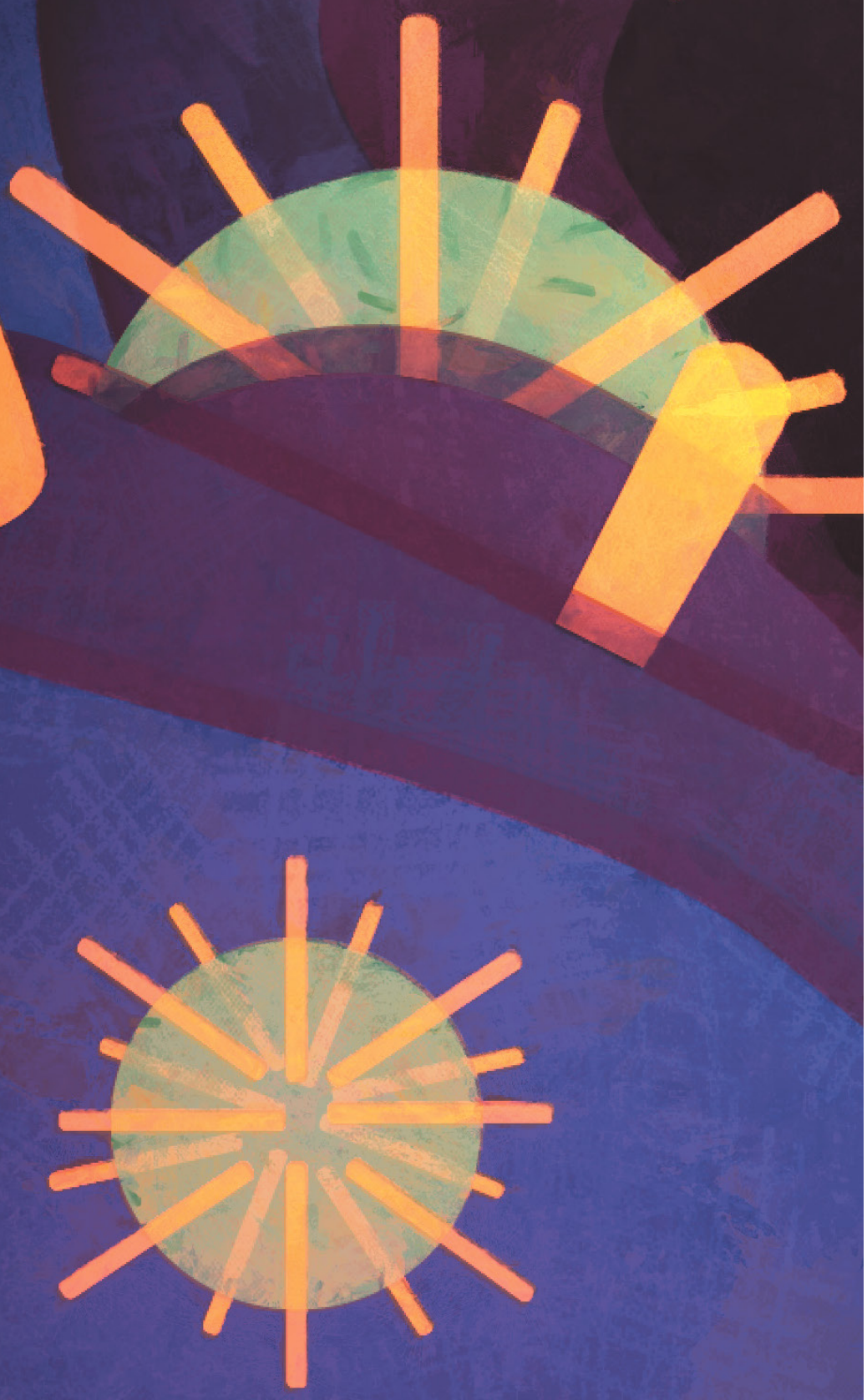


\section{The immune system: a complex network of different players}

\subsection{General overview}

$\mathrm{T}$

he word immunity derives from Latin "immunitatem" that meant "exemption from performing public service or charge, privilege" ${ }^{1}$. The first written description of the concept of immunity has been attributed to the athenian Thucydides who, in 430 BC, described that when the plague hit Athens: "the sick and the dying were tended by the pitying care of those who had recovered, because they knew the course of the disease and were themselves free from apprehensions. For no one was ever attacked a second time, or not with a fatal result" 2. In contemporary scientific language the word "immunity" indicates resistance to particular infection or toxin. Within an organism, the immune system comprises the biological processes and cellular structures that are used to confer protection against host infection. The vertebrate immune system comprises three levels of defense: physical and chemical barriers, the innate immune system and adaptive (or acquired) immune system.

Physical and chemical barriers constitute the first line of protection against pathogens and comprise skin on the outer surfaces of the body as well as the mucous secretions covering the epidermal layers of the inner surfaces of the respiratory, digestive, and reproductive tracts.

The second line of defense consist of the innate immune system that is able to mount effective responses which are not specific to a particular pathogen. Cells of the innate immune system 
can detect the presence of conserved molecular patterns that are characteristic of microbial pathogens, such as viral nucleic acids or bacterial and fungal cell-wall components, defined by Charlie Janeway as pathogen-associated molecular patterns (PAMPs) ${ }^{3}$. These common structures are detected by Pattern recognition receptors (PRRs) and trigger inflammation and activation of the innate immune system. Innate host defenses are mediated by soluble bactericidal proteins, such as the complement cascade and lysozyme, and by cellular responses involving phagocytes (monocytes, macrophages, neutrophils) or natural killer (NK) cells. The actions of the innate immune system are also responsible for alerting the cells that operate the third level of defense, the adaptive immune system ${ }^{4}$.

The adaptive immune system includes T lymphocytes and B lymphocytes armed with $T$ and B cell receptors that recognize specific antigen determinants from infectious agents. The main characteristic of the adaptive immune system is the ability to retain immunological memory to that specific pathogen. Thus, after antigen reencounter, memory $T$ cells and/or B cells undergo clonal expansion inducing a faster and more effective immunological response against the pathogen, leading to a faster clearance of the secondary infection ${ }^{5}$.

However, the dichotomy between innate and adaptive immunity is a simplification that may reduce, but not accurately represent, the complexity of the immune response.

\subsection{Mucosal immune system}

The mucosal surfaces form one of the largest organs of the body and maintain immunological homeostasis through innate and acquired immunity. They provide physical and biological barriers that include epithelial cells, a dense layer of mucins and also anti-microbial peptides. These mucosal sites are thin and permeable barriers that permit gas exchange in the lungs, food absorption in the gut, sensory activities in eyes, nose, mouth and throat and reproduction in uterus and vagina. Continuous exposure to the outside environment, the vast surface area and the necessity for permeability create obvious vulnerability to infection. For that reason it is not surprising that mucosal surfaces are the main portals of entry for microbial pathogens including bacteria, viruses, parasites and also environmental allergens. 


\section{Inductive site}

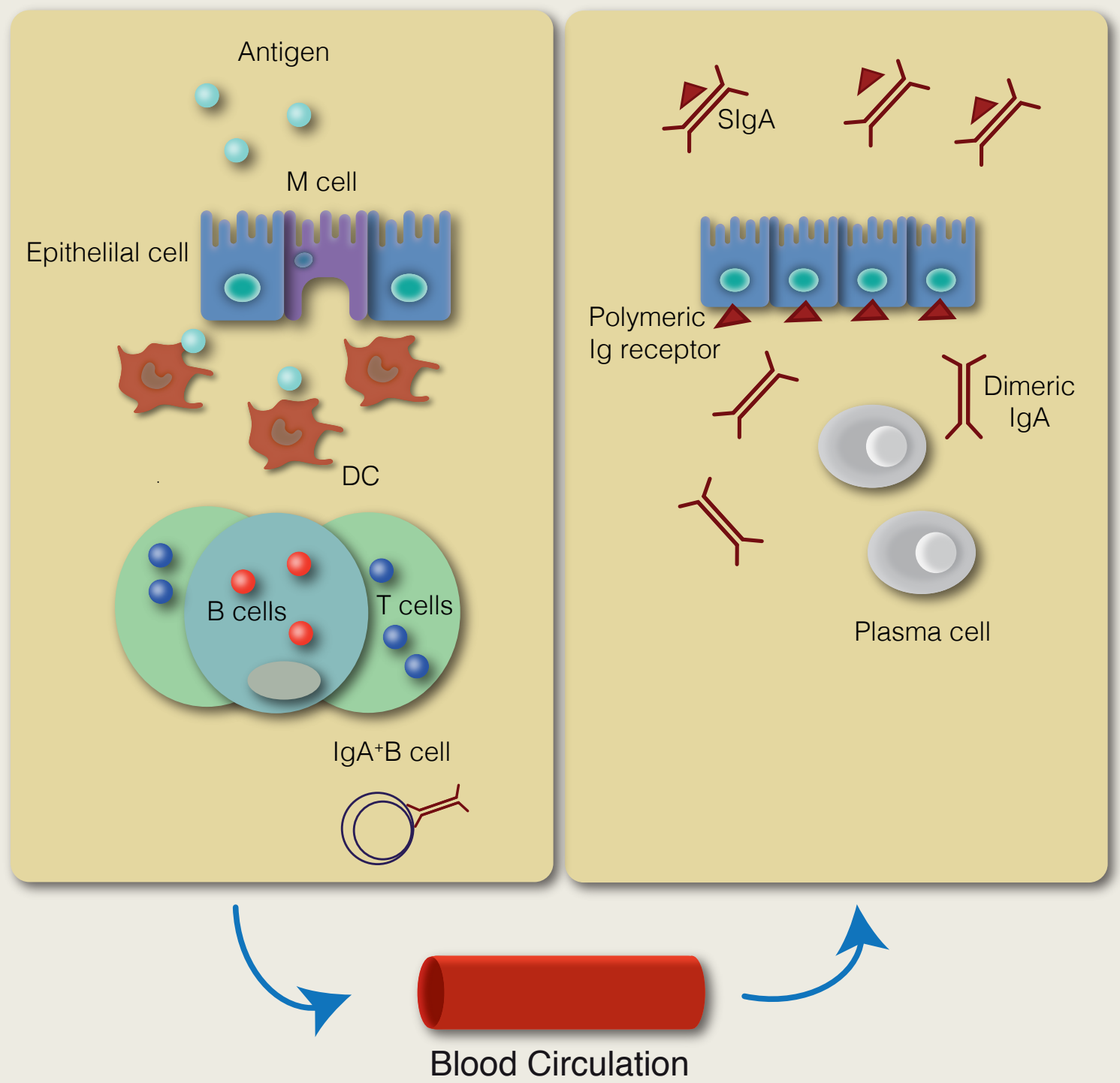

Figure I1. Mucosal immune system: Interplay between inductive and effector sites. Antigens are endocytosed by $\mathrm{M}$ cells located on the epithelium of the mucosa-associated lymphoid tissues and immediately processed by DCs, which transport antigens to underlying $T$ cell zones. Antigen-primed T cells support the induction of $\operatorname{IgA}^{+}$-committed $B$ cells $\left(\lg A^{+} B\right.$ cells) that subsequently migrate to the effector sites where they differentiate into plasma cells. Dimeric or polymeric IgA secreted by plasma cells is bound to polymeric Ig receptor expressed on the basal membrane of epithelial cells (ECs) and transported to the mucosal surface as secretory IgA (SIgA).

In addition, most mucosa-associated organs are colonized by commensal microorganisms which cohabit with the host creating a mutually beneficial environment. "Microbiota" refers to 
the community of microorganisms including bacteria, viruses, fungi, and protozoans, that live in a host ${ }^{6,7}$.The human body contains millions of microbes, many of which are present in mucosal sites. Several studies have already demonstrated the beneficial role of microbiota in shaping the immune system and in maintaining homeostasis ${ }^{8,9}$. Studies using germ free (GF) mice or antibiotic-treated mice have highlighted the protective role of the host microbiota in a variety of pathological settings, such as inflammatory and infectious diseases in the gut and at distal body sites, such as the skin and the lungs ${ }^{10-12}$.

Both intrinsic and environmental factors, including the host genetic background, the diet, the use of antibiotics, the presence of allergens or infectious agents can alter the host-microbiota symbiotic equilibrium, leading to a state of dysbiosis ${ }^{13}$. Dysbiosis can result in disease aggravation or increased susceptibility to new disorders, such as the growth of potentially pathogenic commensals or pathobionts ${ }^{14}$. Therefore, the mucosa needs to distinguish not only between beneficial and detrimental materials, but also resident and pathogenic invading bacteria.

The mucosal immune system (MIS) is composed by inductive and effector sites. The inductive site consists of secondary mucosa associated lymphoid tissue (MALT), including Peyer's patches (PPs) in the small intestine and nasopharynx-associated lymphoid tissue (NALT) in the nasal cavity. Microfold (M) cells in the MALT allow the sampling of antigens that are subsequently processed and presented by antigen presenting cells (APCs) such as dendritic cells (DCs). DCs migrate to the T-cell region of the MALT and present antigen-derived peptide to nalive T cells ${ }^{15}$.

In the B-cell region of lymphoid organs, germinal center formation and antibody class switching occur. In the mucosal immune system, this leads to the development and egress of high affinity immunoglobulin (Ig) $A^{+}$class switched B cells. These cells leave the MALT through efferent lymph vessels and enter the body circulatory system ${ }^{16}$ (Figure I1).

Finally, mucosal immune cells migrate to the mucosal layer of the effector tissue forming the necessary cellular network among Th, regulatory T cells and cytotoxic T cells, B cells, and DCs, together with epithelial cells, to mount an appropriate defensive response ${ }^{17,18}$.

Many pathogens access the body through the mucosal infection and for this reason the interest to develop vaccines that can be delivered through the mucosal route is strongly increased. Moreover initiation of immune reactions at mucosal sites can provide both systemic and mucosal protection. In contrast, conventional vaccines injected into the tissues or blood-stream do not 
usually provide effective mucosal protection ${ }^{19,20}$. These features, in addition to the non-invasive nature of mucosal delivery provide a rational basis for wide scale use of this immunization form. Recently, the sublingual (s.l.) route of administration of bacterial preparations has been proposed as a safer and effective immunotherapy to stimulate strong and long-lasting systemic and mucosal immunity ${ }^{21}$.

\section{Respiratory tract infections}

Respiratory tract infections cause millions of deaths each year worldwide and impose a huge economic burden on the health services of all countries ${ }^{22}$. They can occur in both adults and children and display a variety of clinical manifestations ${ }^{23}$. Respiratory infections can be caused by both bacteria and viruses, including influenza viruses, respiratory syncytial virus, adenovirus, rhinoviruses, Chlamydia pneumoniae, Enterobatteriacee, Hemophilous influenzae, Legionella pneumophila, Moraxella catarrhalis, Mycoplasma pneumoniae, Pseudomonas aeruginosa, and Staphylococcus aureus ${ }^{24}$. In particular both Rhinovirus (RV) and respiratory Syncytial virus (RSV) are often leading causes of viral bronchiolitis in infants and associated with wheezing attacks (WA) in children aged between one and two years ${ }^{25}$. In otherwise healthy infants and young children, respiratory tract infections (RTIS) are extremely common and, in a number of cases, infections recur frequently causing significant medical, social, and economic problems ${ }^{26}$. As the respiratory tract is a major portal through which viruses enter to initiate infection, various defence mechanisms have evolved to prevent and control infection by viruses and other pathogens.

In humans the respiratory tract consists of the upper respiratory tract (including the nose, mouth and pharynx) and the lower respiratory tract (which consists of the trachea, bronchi and lungs), separated by the lymphoid tissue of Waldeyer's ring (including the pharyngeal and palatine tonsils). Stromal cells (typically CD45 non-haematopoietic cells) and haematopoietic cells (CD45 ${ }^{+}$bone marrow-derived cells) constitute the cellular network of the lower respiratory tract. Among the CD45 stromal cells, the type I and type II alveolar epithelial cells and the conducting airway epithelial cells are of particular importance as infection of these cells by viruses and the 
subsequent inflammation can compromise respiratory function and can result in acute respiratory distress syndrome (ARDS). Moreover, these cells are important targets for infection by certain type A influenza virus strains, most notably the highly pathogenic avian H5N1 viruses ${ }^{27}$. In case of severe lung inflammation associated with respiratory infection the immune system needs to play a dual role controlling both the elimination of the virus and the tissue inflammation to prevent acute respiratory failure. Furthermore, during the recovery or resolution phase of infection, the immune system orchestrates tissue repair to restore normal lung architecture and function avoiding permanent defects in respiratory function.

If early virus replication is not controlled by primary target cells such as epithelial cells, then released virions and the contents of dying or dead infected cells can be taken up by a variety of $A P C s^{28}$. In the respiratory tract the first $C D 45^{+}$immune cells that encounter viral antigens are the alveolar macrophages that can rapidly eliminate large numbers of microorganisms from the lung. Moreover recent evidence indicates that alveolar macrophages can migrate from the lung to the draining lymph nodes under homeostatic conditions and can serve as antigen carriers following bacterial infection ${ }^{29}$. Nonetheless their contribution to the induction of adaptive immune responses in the draining lymph nodes is currently undefined.

DCs reside within the pulmonary interstitium, and they can extend their dendritic processes between airway epithelial cells, making them strategically positioned to sample airway particulates, such as viruses. Several phenotypically and functionally distinct subsets of respiratory DCs have been characterize in murine models. These populations include $\mathrm{CD} 103^{+}$and $\mathrm{CD} 11 \mathrm{~b}^{\text {hi }} \mathrm{CD} 103^{-}$ respiratory DCs, plasmacytoid DCs (pDCs) that are recognized as major producers of type I interferons (IFNs) during infection, and monocyte-derived DCs that can take up particles in the inflamed lung and migrate to the draining lymph nodes. Activated $\mathrm{CD} 103^{+}$respiratory DCs produce modest levels of pro-inflammatory mediators, whereas CD11b $b^{\text {hi }}$ respiratory DCs are major chemokine producers in response to pulmonary inflammation ${ }^{30}$. Antigen acquisition and activation of immature respiratory DCs results in their migration out of the infected lungs along chemokine gradients of Chemokine ( $\mathrm{C}-\mathrm{C}$ motif) ligand (CCL) 21 and sphingosine-1-phosphate (S1P) to the lymph nodes that drain the infected lung. Once in the lymph nodes, these DCs participate in initiating adaptive immune responses to the respiratory virus ${ }^{30}$.

Although genetic characteristics and several environmental factors play a role in favoring RTI development, immunological immaturity is the most important factor that explains the high in- 
cidence and tendency of these infections to recur ${ }^{31}$. Recurrence of respiratory infections during the first years of life affects both bronchoalveolar and vascular development of the lungs and this could lead to long-term effects. RRTI are characterized by at least three episodes of fever, cough, asthma, wheezing without severe impairment of respiratory functions ${ }^{31}$. In recent years, following the increase in the incidence of antibiotic resistance, interest in preventive treatment has been intensified.

\section{Bacterial Immunostimulants in clinical settings of RRTI}

In 1989, Strachan et al. observed that children growing up in large families had decreased chances of developing hay fever or eczema. This was the starting point for the original 'hygiene hypothesis' as he postulated that the increased incidence of allergy was related to 'declining family size, improvements in household amenities, and higher standards of personal cleanliness', reducing 'the opportunity for cross infection in young families' ${ }^{32}$. Since then, numerous studies have supported this hypothesis, showing that exposure to bacteria, viruses, helminths or microbe-derived products could protect from allergy. In particular a German prospective birth cohort study demonstrated that a higher frequency of infections, excluding those in the lower respiratory tract, such as herpes simplex virus infection or sinus infection, in children younger than three years of age correlated with protection from allergic sensitization and asthma ${ }^{33}$.

However the hygiene hypothesis received criticism based on the evidence that not all pathogens are protective; for instance, RSV or rhinovirus are associated with a higher risk of developing wheeze and asthma up to adulthood ${ }^{34}$.

Therefore, as alternatives to the hygiene hypothesis, Rook et al. proposed the 'old friends' hypothesis, and Haahtela et al. the 'biodiversity hypothesis' of allergy, both of which state that the observed increase in allergies is due to the loss of symbiotic relationships with parasites and bacteria that were once beneficial to our evolution ${ }^{35,36}$. 
As a consequence of the increasing recognition of the protective role that bacterial commensals play in lung homoeostasis, a number of approaches have been developed that target the microbiota-host immune system interaction, with the goal of improving both prevention and treatment of respiratory diseases. Administration of microbes (using probiotics or faecal transfer), microbe components, or products favouring microbial growth (e.g., prebiotics) has been suggested to confer host protection through direct competition with disease-causing microbes, enhancement of epithelial barrier functions, or immune modulation during respiratory diseases ${ }^{37,38}$. Immunostimulating agents of bacterial origin have been studied and found to be able to modulate both innate and adaptive branches of the immune system and to protect against respiratory tract infections ${ }^{31}$. The polyvalent bacterial preparations that have been used for the treatment of RRTIs contain different formulations of bacterial strains which are common pathogens in the respiratory tract and which could be present as whole inactivated microorganisms, lysates or defined cellular components ${ }^{39}$. Different studies have shown that the oral administration of bacterial immune stimulants ameliorates RRTIs in adults and children by reducing the number, duration and severity of infectious clinical episodes. A clinical trial that included 232 children aged 3-5 years, showed that the treatment with polyvalent mechanical bacterial lysates significantly reduced the rate of upper respiratory tract infections ${ }^{40}$. Another study involving 188 pediatric patients showed that in patients treated with bacterial preparation, the rate of infection was reduced by $50 \%$ and this was sustained for half a year after the end of drug administration. In this case adverse reactions to the treatment were few and transient ${ }^{41}$. In 2010 a randomized, double-blind, placebo-controlled study was published and included 75 children 1 and 6 years-old who suffered from recurrent WA due to acute respiratory tract illness. Participants who received bacterial lysates showed a significant reduction in the rate and duration of WA over placebo treated children ${ }^{42}$.

\subsection{The Polybacterial mucosal vaccine MV130}

MV130 is a polybacterial mucosal vaccine composed of different proportions of whole heat-inactivated Gram-positive and -negative bacteria often present in the nasal mucosa and frequently causative agents of upper and lower respiratory infections in Europe (see Materials and Methods table 1) ${ }^{43}$. This thesis work is framed in a collaborative effort that includes a phase 3 randomized, double-blind, placebo-controlled, parallel-group trial that was performed by Dr. A. Nieto and collaborators to evaluate the safety and efficacy of MV130. Children under 3 years old who had suffered more than three WA during the previous year were treated with MV130 or placebo for 
six months and monitored for another six months. An important reduction in the frequency and severity of WA was shown in children treated with MV130. Moreover, clinical data has shown that MV130 significantly reduced the rate of infections in patients suffering from RRTIs. Concretely, a prospective open pilot study in a cohort of patients with RRTIs was published in $2011^{43}$ in which 17 patients with RRTIs received s.I. administration of MV130 daily for six months. In the subsequent six months follow up, there was a significant reduction in the patient's rate of RRTIs compared with one year prior to initiation of therapy. Moreover immunological analysis performed at the baseline and at the end of immunization showed a significant increase in the proliferating capacity of the antigen-specific memory $\mathrm{CD}^{+} \mathrm{CD}^{+} \mathrm{T}$ cells ${ }^{43}$. Another preclinical study showed that human DCs treated in vitro with MV130 acquire the capacity to generate Th1, Th17 and IL-10-producing T cells. This was due to the activation of Receptor interacting protein kinase 2 (RIPK2) and Myeloid differentiation primary response 88 (MyD88) mediated signalling pathways under the control of IL-10. Moreover s.I. immunization of mice with MV130 also lead to generation of Th1, Th17 and IL-10 responses ${ }^{44}$. Although the beneficial role of bacterial extracts has been demonstrated, the use of whole inactivated bacteria from selected species is less explored and the mechanism of action of this cross-protection remains unknown.

\section{Trained immunity}

\subsection{The origins of the "innate immune memory" theory}

There are some studies showing that in plants and in some invertebrates, innate immune responses exhibit memory characteristics after the first encounter with a pathogen. In particular it has been described that plants are able to acquire resistance against different pathogens ${ }^{45}$. This phenomenon of resistance that starts in the infection site and spreads throughout the tissues of the plant has been called "systemic acquired resistance" (SAR) ${ }^{46}$. SAR can be defined as the mechanism by which plants inoculated with attenuated microorganisms are protected for long 
periods against subsequent infections with a broad spectrum of pathogens including viruses, bacteria, and fungi ${ }^{46,47}$.

Moreover, recent studies demonstrate the ability of invertebrates to develop resistance to secondary infections due to a first encounter with related or unrelated pathogen ${ }^{48}$. For example, Lipopolysaccharide (LPS) injection in mealworm beetles was shown to confer protection against fungi ${ }^{49}$.

In the 2011, on the basis of these evidences Netea and colleagues introduced a new concept of immune memory related to innate cells termed Trained Immunity ${ }^{50}$.

\subsection{Global overview}

Trained immunity describes the enhanced state of innate immune cells after exposure to certain infectious agents, by which they undergo long-lasting changes promoting an increased resistance to subsequent related or unrelated infections ${ }^{50-52}$.

Trained immunity has a number of defining characteristics. First of all it is independent of adaptive immunity, as demonstrated by studies performed on mice lacking B and T cells ${ }^{51,53,54}$. It is driven by a specific set of innate immune cells, in particular it has been described in monocytes, macrophages ${ }^{55,56}$ and Natural Killer (NK) cells ${ }^{57-59}$. Recently, the first evidence of trained immunity in dendritic cells in a pulmonary fungal vaccine model system has been shown ${ }^{60}$.

Different stimuli have been described to induce trained immunity, among them are infectious agents such as Bacillus Calmette-Guerin (BCG) ${ }^{54}$, or Candida albicans ${ }^{51}$ and microbial components such as the fungal cell wall component $\beta$-glucan ${ }^{51}$ or the muramyl dipeptide ${ }^{61}$. Also some metabolites such as oxidized low-density lipoprotein (oxLDL) ${ }^{62}$, mevalonate ${ }^{63}$, fumarate ${ }^{64}$ bovine milk ${ }^{65}$ or uric acid ${ }^{61}$ can play a role in the induction of trained immunity.

Induction of innate memory involves recognition of stimuli through receptors specific for PAMPs and danger-associated molecular patterns (DAMPs) ${ }^{50,67}$. In this regard the C-type lectin receptor (CLR) Dectin-1 is required for $\beta$-glucan sensing ${ }^{68}$ and for the subsequent training of monocytes ${ }^{69,70}$. Both in presence of laminarin, a Dectin-1 inhibitor, and in cells/individuals genetically deficient in Dectin-1, the trained response is abolished ${ }^{51}$. Sensing of $\beta$-glucan by Dectin-1 induces phosphorylation of protein kinase B (Akt) with subsequent activation of mammalian Target of Rapamycin (mTOR) that is responsible for the glycolysis induction through Hypoxia 
Inducible Factor $1 \alpha$ (HIF1 $\alpha)^{71}$. Similarly, the mechanisms responsible for training of monocytes by BCG is dependent on the nucleotide-binding oligomerization domain (NOD) protein,NOD2, as monocytes isolated from patients with a complete NOD2 deficiency could not mount a trained response. In contrast, the use of monocytes from a Dectin-1 deficient individual, did not abolish the training ability induced by BCG ${ }^{54}$.

\subsection{Trained immunity hallmarks}

Trained immunity is characterized by immunological mechanisms, metabolic reprogramming and epigenetic changes (Figure I2).

\section{Immunological mechanisms}

Increased cytokine production upon rechallenge is a characteristic aspect of trained immunity ${ }^{72,73}$. In particular it has been shown that in trained cells the proinflammatory cytokines tumor necrosis factor $\alpha$ (TNF $\alpha$ ), interleukin (IL)- 6 and IL-1 $\beta$ are augmented in response to a second challenge $51,56,61,69$. Also Interferon $\gamma$ (IFN- $\gamma$ ) expression is modulated, mainly by trained NK cells ${ }^{57,74}$ whereas IL- 10 varied among studies ${ }^{51,56,75-77}$. This enhanced response has been analyzed using several trained immunity models in vitro and in vivo. In the prototypical in vitro model, monocytes or macrophages can be primed with $\beta$-glucan in vitro for 24 hour and after a resting period without stimulus they are secondarily rechallenged with LPS ${ }^{69,71}$. The resting period is needed to reflect in vitro the long-lasting effect of trained immunity and usually in human peripheral blood mononuclear cell (hPBMCs) and monocytes it takes around 6- or 7-days ${ }^{51,61}$. In vivo experiments have also been performed using different stimuli. Low doses of live C. albicans, administered in mice one week before the second challenge, confers protection against intravenous (i.v.) infection with a lethal dose of live C. albicans or with heterologous Staphylococcus aureus septicaemia, ${ }^{51,70}$. Also, intraperitoneal administration of $\beta$-glucan at day -7 and -4 induced protection against i.v. inoculation of both S. aureus and a lethal dosis of C. albicans ${ }^{51,70}$. Moreover, mice pre-treated with both $C$. albicans and $\beta$-glucan, produce increased levels of TNF $\alpha$, IL-6, IL-1 $\beta$ or IL-10 in serum when they are treated with LPS, with some differences in cytokines dependent on the model used $51,64,70,77$. This acquired resistance is dependent on myeloid cells, as protection was 
prevented by affecting macrophage function or monocyte recruitment ${ }^{51,71}$. The tuberculosis vaccine, BCG, has been used in vivo, both in mice and in humans, as a trained immunity stimulus to confer protection against unrelated infections. In particular, mice that received BCG vaccination were protected against lethal C. albicans infection and this protection was shown to be independent of adaptive immune system ${ }^{54}$. Spleen cells and peritoneal macrophages, isolated from mice 7 days after administration of BCG, produced higher levels of trained immunity associated cytokines compared to the control cells, upon rechallenge with different stimuli. Finally, healthy volunteers who received BCG vaccination were protected from experimental Yellow fever viral infection and plasma analysis 5 days post-infection showed the induction of trained immunity associated cytokines ${ }^{78}$.

However, training stimuli do not protect against all infections. For instance, it has been described that i.v. administration of BCG was not protective in a lethal Influenza A/Anhui/1/2013 (H7N9) challenge infection in mice ${ }^{79}$.

\section{Metabolic rewiring}

Several studies have shown that a shift from oxidative phosphorylation to aerobic glycolysis (the Warburg effect) mediated by Akt / mTOR / HIF-1 $\alpha$ pathway is a key mechanism for trained immunity responses ${ }^{64,71,80}$. Inhibition of glycolysis with the drug metformin, which acts through AMP-activated protein kinase (AMPK) activation and subsequently mTOR inhibition abrogates the protective effects of $\beta$-glucan on monocytes in vitro ${ }^{71}$. Moreover administration of metformin to mice during and after primary infection with a low-inoculum C. albicans completely inhibited the protective effects against disseminated candidiasis demonstrating the crucial role of mTOR-mediated effects in trained immunity ${ }^{71}$. In $\beta$-glucan trained monocytes glucose was converted into lactate while some intermediates of TCA cycle such as fumarate and succinate control methylation and acetylation of histones ${ }^{64}$. Consistently fumarate is able to inhibit the histone demethylases that belong to the KDM5 family, leading to a subsequent increase in histone methylation and open chromatin, favoring the expression of pro-inflammatory genes ${ }^{64}$.

The cholesterol synthesis pathway also plays an important role in the induction of $\beta$-glucan mediated trained immunity in macrophages ${ }^{81}$. In line with this, a growing body of evidence has shown that trained immunity might play a central role in the pathogenesis of atherosclerosis. Brief exposure of monocytes to a low concentration of oxLDL induces a long-lasting proathero- 
genic macrophage phenotype via epigenetic histone modifications, characterized by increased proinflammatory cytokine production and foam cell formation ${ }^{62}$. Moreover, exposure of mice to high-fat diet for a short period induces long-term transcriptional and functional reprogramming of hematopoietic precursors. This leads to a consistent increase in systemic inflammation through a mechanism dependent on NLRP3 and IL-1 ${ }^{82}$. Interestingly, mevalonate, a metabolite of the cholesterol synthesis pathway, is able to amplify the induction of trained immunity through an IGF1R-mTOR mediated pathway ${ }^{63}$. This is reflected in the trained immunity phenotype that characterizes Hyper Immunoglobulin D syndrome patients who accumulate mevalonate, presenting a constitutive increased cytokine production which in turn is responsible for the attacks of sterile inflammation in this disease ${ }^{63}$.

Different studies have shown that glutamine metabolism is involved in trained immunity process as it is a source of fumarate and succinate for the TCA cycle and inhibition of glutaminolysis in mice impair $\beta$-glucan triggered trained immunity ${ }^{64}$.

\section{Epigenetic remodelling}

Changes in cellular metabolism are accompanied by sustained changes in the epigenome, mainly via histone methylation and acetylation ${ }^{80,81,83}$. In this regard terminally differentiated cells, such as monocytes and macrophages, undergo changes in their histone acetylation and methylation marks upon stimulation, affecting their gene expression patterns in response to a second stimulus ${ }^{71,81}$. Genome-wide analyses have revealed the presence of three histone methylation marks, positively associated with gene expression: trimethylation at lysine 4 of histone H3 (H3K4me3) in active promoters, monomethylation at lysine 4 of histone $\mathrm{H} 3$ (H3K4me1) that marks enhancers, and acetylation at lysine 27 of histone H3 (H3K27Ac) in both elements ${ }^{52,84}$. Several studies describe the enrichment of $\mathrm{H} 3 \mathrm{~K} 4 \mathrm{~m} 3$ at promoters associated with trained immunity, for instance at genes encoding pro-inflammatory cytokines and intracellular signaling molecules after stimulation with $\beta$-glucan ${ }^{51,81}$, as well as at promoters of genes implicated in atherogenesis in cells trained with oxLDL ${ }^{62}$. Furthermore, the heterologous benefit of BCG vaccination is associated with persistent $\mathrm{H} 3 \mathrm{~K} 4 \mathrm{~m} 3$ enrichment at the promoters of genes encoding TNF $\alpha$, IL-6, and TLR4 ${ }^{54}$.

Accordingly, trained immunity induction was prevented using both histone methylation and acetylation inhibitors ${ }^{51,61,71}$. In particular the pan-methyltransferase inhibitor $5^{\prime}$-methylthioadenosine (MTA) prevents the induction of training by $\beta$-glucan ${ }^{61}, \mathrm{BCG}^{54}$, and oxLDL ${ }^{62}$. Supporting 
also the importance of acetylation, pre-incubation with the histone acetyltransferase inhibitor epigallocatechin-3-gallate (EGCG) before $\beta$-glucan stimulation also abolished trained immunity induction ${ }^{61}$. Resveratrol, by activating the deacetylase sirtuin-1 had an identical effect ${ }^{71}$. Trained immunity phenomenon can be considered as the opposite to the endotoxin tolerance that on turn is defined as the memory-induced decreased responsiveness on innate immune cells ${ }^{85}$. Importantly, consistent with these divergent responses, the epigenetic signatures triggered in $\beta$-glucan trained macrophages differed from the one found in LPS-tolerant macrophages ${ }^{81,86,87}$. Moreover, the LPS-induced tolerant state could be reverted when stimulating tolerant cells with $\beta$-glucan. Exposure of LPS-tolerized cells to $\beta$-glucan for 24 hours in vitro restored their ability to produce inflammatory cytokines in response to second stimuli. Importantly, monocytes isolated from volunteers with experimental endotoxemia presented a more responsive phenotype when restimulated with $\beta$-glucan ex vivo. This process was associated with the restoration of H3K27ac at enhancers previously precluded by LPS exposure, demonstrating the ability for $\beta$-glucan to effectively reprogram innate immune memory ${ }^{88}$.

\section{Progenitor reprogramming}

Modulation of myeloid progenitors in the bone marrow has been shown as an integral component of trained immunity ${ }^{89,90}$. Administration of $\beta$-glucan to mice induces expansion of hematopoietic and myeloid progenitor pool in the bone marrow compartment with a particular bias to the myeloid lineage (multipotent progenitors (MPPs) and granulocyte-macrophage progenitors $(G M P s))^{89}$. This expansion was associated with alterations in metabolic pathways in progenitor cells, with upregulation of mevalonate pathway, glycolysis and cholesterol metabolism, which also accompany the induction of trained innate immunity in mature cells ${ }^{71,80}$. Progenitor cells from $\beta$-glucan-treated mice, showed enhanced glycolysis that was retained also after chemotherapy. In addition they present resistance to DNA damage upon hematopoietic stress, induced by systemic LPS challenge or chemotherapy ${ }^{89}$.

BCG treatment is also able to trigger hematopoietic stem cells expansion (HSCs). Moreover, BCG alters the transcriptome profile of HSCs and induces myelopoiesis. Finally, i.v. administration 
of BCG also educate hematopoietic stem cells (HSC) to generate epigenetically modified macrophages that provide significantly better protection against virulent $M$. tuberculosis infection ${ }^{90}$.

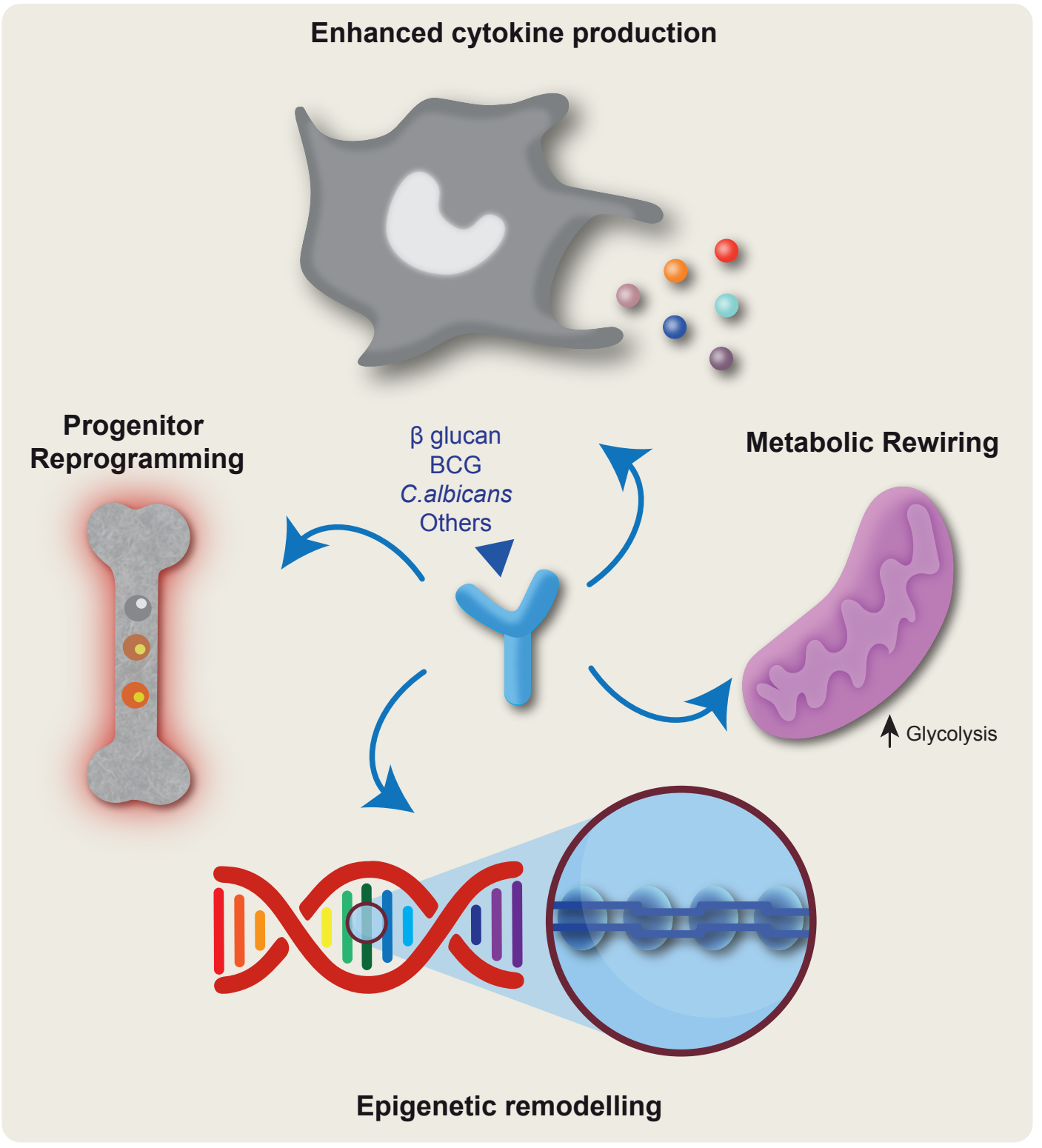

Figure 12. Hallmarks of trained immunity: Trained immunity involves epigenetic and metabolic reprogramming of the innate immune cells, resulting in enhanced cytokine production in response to a second related or unrelated challenge. Moreover it induces long-term effects through the reprogramming of bone marrow myeloid progenitors. 

OBJECTIVES 
3
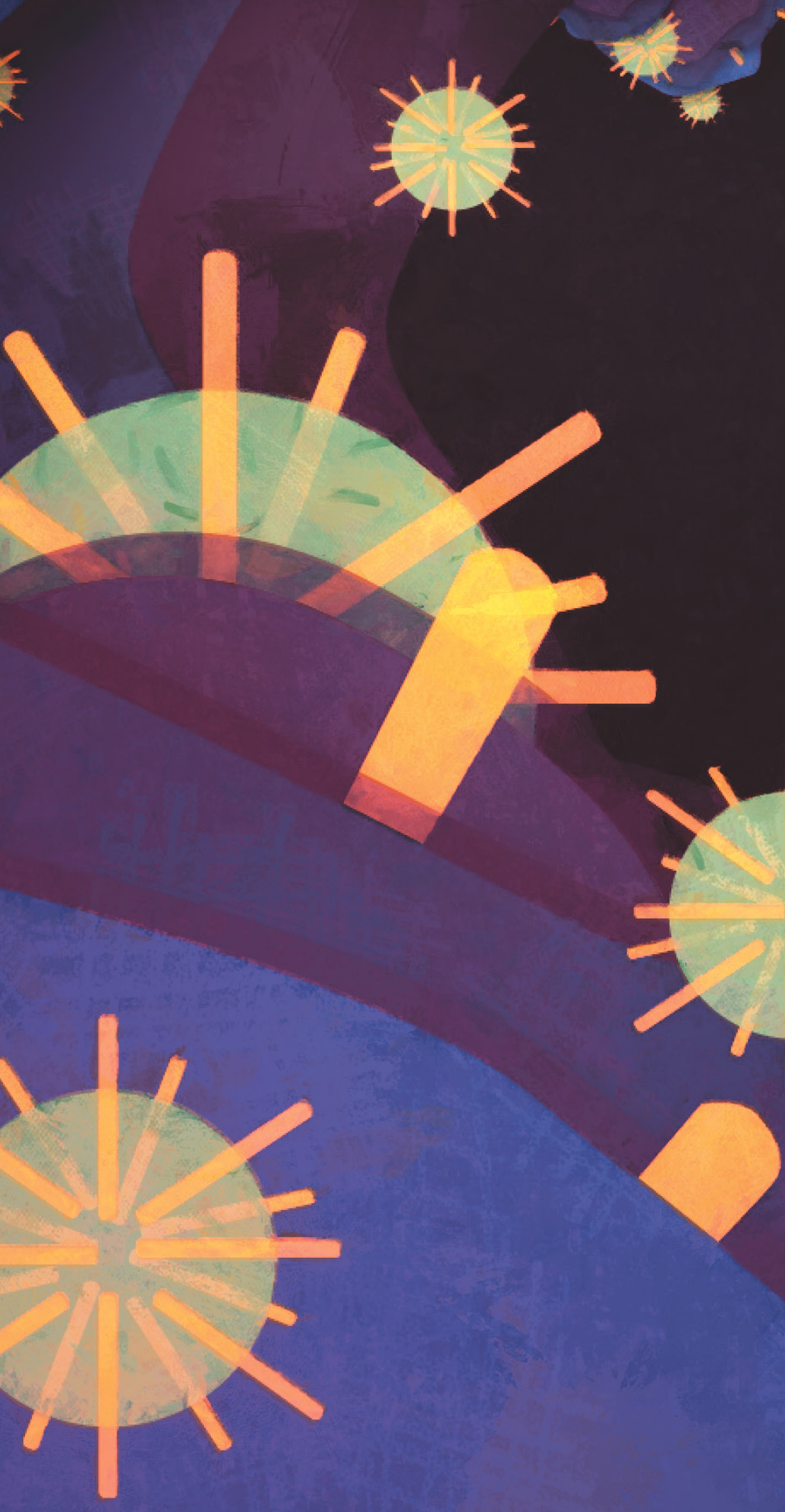


\section{Objectives}

his thesis project aims to investigate the mechanism of action of the polybacterial mucosal vaccine MV130 that has been described to reduce the recurrence of RTI in

adults and the number of WA in children. Specific objectives are as follows:

1.- Evaluate the ability of MV130 to cross-protect against unrelated viral RTIs in mouse models

- Identification of appropriate administration route

- Testing the efficacy of MV130 against different viral pathogens

- Study the immunomodulatory effects of MV130 in lung infiltrates

2.- Test whether MV130 complies with hallmarks of trained immunity

- Effects of MV130 against systemic C. albicans infection

- Test dependency of MV130 protective effect on adaptive immunity

- Ability of MV130 to educate bone marrow progenitors

- Role of mTOR in MV130 mediated protection against viral infection

3.- Address whether MV130 induces features of trained immunity in human monocytes

- Enhanced cytokine production

- Epigenetic reprogramming

- Metabolic rewiring 

MATERIALS

\author{
AND \\ METHODS
}




\section{Materials and methods}

\section{Reagents}

eagents used were as follows: Dolethal (pentobarbital sodium, Vetoquinol), Es-
cherichia coli lipopolysaccharide (LPS-EK, Invivogen), methyltransferase inhibitor
5'-Deoxy-5'-(methylthio) adenosine (MTA, Sigma) and demethylase inhibitor pargyline (Sigma). The polybacterial preparation MV130 and the excipient were provided by INMUNOTEK S.L. and compositions are detailed in the Box MM1 below.

\begin{tabular}{|l|l|}
\hline MV130: & Excipient: \\
Glycerol & Glycerol \\
Sodium chloride & Sodium chloride \\
Artificial pineapple essence & Artificial pineapple essence \\
$10^{9}$ whole-cell inactivated bacteria/mL: & \\
Streptococcus pneumoniae (60\%) & \\
Staphylococcus aureus (15\%) & \\
Staphylococcus epidermidis (15\%) & \\
Klebsiella pneumoniae (4\%) & \\
Moraxella catarrhalis (3\%) & \\
Haemophilus influenzae (3\%) & \\
\hline
\end{tabular}

Box MM1: Detailed composition of the polyvalent bacterial preparation and its excipient. 


\section{Microorganism}

- Vaccinia virus (VACV) Western Reserve (WR) strain was kindly provided by J.W. Yewdell and J.R. Bennink (NIH, Bethesda, Maryland, USA). Stocks were generated in CV-1 cell line monolayers and subsequently used as clarified sonicated cell extracts.

- Influenza A/Puerto Rico/8/34 virus was a gift from E. Nistal-Villán (San Pablo CEU University, Madrid, Spain).

- The clinical isolate Candida albicans (strain SC5314) was kindly provided by Prof. C. Gil (Complutense University, Madrid, Spain). The fungus was grown on yeast extract-peptone-dextrose (YPD)-agar plates (Sigma) at 30ㅇ for 48 hours, in order to maintain the degree of virulence.

\section{Mouse strains}

Mice, all in C57BL/6 background, were bred at CNIC under specific pathogen-free conditions. Mouse colonies included Wild-type (WT) and Rag1-/- (B6.129S7-Rag1tm1Mom/J), both from The Jackson Laboratory. Experiments were performed with sex- and age-matched mice. Experiments were approved by the Animal Ethics Committee at CNIC and conformed to Spanish law under Real Decreto 1201/2005. Animal procedures were also performed in accordance to EU Directive 2010/63EU and Recommendation 2007/526/EC.

\section{Cells}

\section{Cell lines}

- $\quad$-1 cells

CV-1 cell line, derived from African green monkey kidney, was a gift from M. del Val (CSIC/Autónoma University, Madrid, Spain). Cells were cultured in Dulbecco's Modified Eagle's Medium (DMEM, Sigma) supplemented with 10\% heat-inactivated fetal calf serum (FCS, Sigma), $100 \mu \mathrm{g} / \mathrm{mL}$ penicillin and $100 \mu \mathrm{g} / \mathrm{mL}$ streptomycin (both from Lonza) and maintained at $37^{\circ} \mathrm{C}$ and $5 \% \mathrm{CO}_{2}$. CV-1 cells were seeded in monolayers on 24-well plates (Corning) and left 24 hours before viral infection. 
- $\quad$ 929 cells

L929 cell line (ATCC ${ }^{\circledR}$ CCL-1TM) was grown in R10 on $175 \mathrm{~cm}^{2}$ cell culture flasks (Stemcell). Supernatants were obtained by filtering 15-days long cultures over 0.22 $\mu \mathrm{m}$ Stericup Filter unit (Merck Millipore) and were used to subsequently supplement the medium for the growth of bone marrow derived macrophages.

\section{Mouse cell cultures}

- Bone marrow derived macrophages (BMDM)

Mice were sacrificed in a $\mathrm{CO} 2$ chamber and both femurs and tibiae were collected and flushed. After the lysis of red blood cells with (RBC) Lysis Buffer (Sigma, St. Louis, MO) for 3 minutes at room temperature (RT) cells were resuspended in Roswell Park Memorial Institute Medium (RPMI 1640, Sigma) supplemented with $10 \%$ heat-inactivated fetal bovine serum (FBS, Sigma), 1 mM pyruvate (Lonza, Bassel, Switzerland), $100 \mu \mathrm{M}$ non-essential aminoacids (Thermo Fisher Scientific, Walthman, MA), $2 \mathrm{mM}$ L-glutamine, $100 \mathrm{U} / \mathrm{ml}$ penicillin, $100 \mu \mathrm{g} / \mathrm{ml}$ streptomycin (all three from Lonza) and $50 \mu \mathrm{M}$ 2-mercaptoethanol (Merck, Darmstad, Germany), herein called R10, plus M-CSF (30\% mycoplasma-free L929 cell supernatant) and plated in non-treated cell culture plates (Corning, Corning, NY) at 37으 for 5 days. At day 5, BMDMs were detached using phosphate buffered saline (PBS, Gibco) supplemmented with $5 \mathrm{mM}$ ethylene diamine tetra acetate (EDTA) (PBS/EDTA, Life Technologies), counted using CASY cell counting technology and used as desired.

\section{Human cell cultures}

Buffy coats from healthy volunteers were obtained from Andalusian Biobank after approval by the local Instituto de Salud Carlos III (ISCIII) Research Ethics Committee. Peripheral blood mononuclear cells (PBMCs) were isolated by differential centrifugation using Biocoll Separating Solution (Cultek, Madrid, Spain). Total PBMCs were resuspended in RPMI 1640 (Sigma), plated in 96well plates $\left(5 \cdot 10^{6}\right.$ cells in $100 \mathrm{uL} /$ per well) and incubated at $37^{\circ} \mathrm{C}$ and $5 \% \mathrm{CO}_{2}$. After $1 \mathrm{~h}$ cells were washed with warm PBS resuspended in RPMI 1640 (Sigma) supplemented with 10\% heat-inactivated FBS, 2 mM L-glutamine, $100 \mathrm{U} / \mathrm{ml}$ penicillin and $100 \mu \mathrm{g} / \mathrm{ml}$ streptomycin (all three from Lonza). 


\section{In vivo models}

\section{Viral infection model}

WT mice were challenged through intranasal route with $50 \mu \mathrm{l}$ of MV130 (109 bacteria/mL) or Excipient 3 times per week for a time period of 3 weeks. After one week of resting, mice were

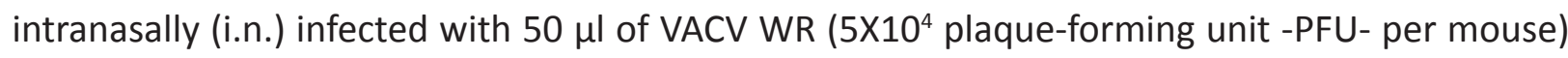
or Influenza A (2X10 PFU per mouse), both diluted in sterile PBS, and mice monitored daily for weight, general health, and survival, following the institutional guidance.

For the evaluation of the lung viral titer, 3 days post infection with VACV WR, mice were sacrificed with a lethal dose $(100 \mathrm{mg} / \mathrm{kg}$ ) of pentobarbital (Dolethal, Vetoquinol) and perfused with $20 \mathrm{~mL}$ of cold PBS.

For both characterization of lung immune cells and evaluation of myeloid progenitors reprogramming, after MV130/excipient treatment mice were not infected. In the first case animals were sacrificed with pentobarbital one day or one week after the last challenge. After perfusion with $20 \mathrm{~mL}$ of cold PBS, lungs were collected for flow citometry analysis. In the second case, just one week after the last challenge, mice were sacrificed in $\mathrm{CO}_{2}$ chamber. Bone marrows were collected and differentiated into macrophages, which were subsequently used for trained immunity in vitro assay.

For metformin inhibition experiments, WT mice were i.n. challenged with $50 \mu \mathrm{l}$ of MV130 (10 bacteria/mL) or Excipient 3 times per week for 2 weeks, and the pharmacological inhibitor metformin hydrochloride (Sigma) was administered ad libitum in drinking water $(0.3 \mathrm{mg} / \mathrm{mL}$ of metformin, corresponding to an approximate dose of $100 \mathrm{mg} / \mathrm{Kg}$ per day) from 1 day before the first MV130/excipient challenge to four days after the last dose. One week after the last challenge, mice were i.n. infected with $50 \mu$ of Influenza A ( $2 \times 10^{3}$ PFU per mouse) as previously described and monitored daily for weight, general health, and survival, following the institutional guidance.

\section{Candida albicans infection model}

Mice were i.n. challenged with $50 \mu \mathrm{L}$ of MV130 $\left(10^{9}\right.$ bacteria/mL) or excipient on days -7 and -4 , following the classical scheme used for $\beta$-glucan training. At day 0 , mice were intravenously (i.v.) infected with $3 \times 10^{5}$ (WT mice) or $10^{5}$ (Rag1-deficient mice) C. albicans prepared in sterile PBS. Afterwards general health and survival were monitored daily following the institutional guidance. 


\section{Ex Vivo esperiments}

\section{Lung viral titration}

The whole lung was aseptically removed, harvested in RPMI and homogenized to single cell suspension after digestion with Liberase TL (Sigma) $0.25 \mathrm{mg} / \mathrm{mL}$ at 37 으 for 30 minutes. The homogenates were freeze-thawed twice, sonicated for $3 \mathrm{~min}$ and then serially diluted in DMEM. Monolayers of CV-1 cells were seeded on 24-well plates (Corning) and maintained in Dulbecco's Modified Eagle's Medium (DMEM-Sigma) supplemented with 10\% heat-inactivated FCS, Sigma, $100 \mu \mathrm{g} / \mathrm{ml}$ penicillin and $100 \mu \mathrm{g} / \mathrm{ml}$ streptomycin (both from Lonza) at $37^{\circ} \mathrm{C}$ and $5 \% \mathrm{CO}$. After $24 \mathrm{~h}$ culture medium was removed and the previously obtained viral dilutions, were added to each well of CV-1 in a volume of $200 \mathrm{uL}$ and incubated again at $37^{\circ} \mathrm{C}$ and $5 \% \mathrm{CO}$. After $1 \mathrm{~h}, 0.5 \mathrm{ml}$ DMEM containing $10 \%$ FBS were added to each well and cells were left in the previous described conditions. After $36 \mathrm{~h}$, culture medium was removed and cells were stained for $5 \mathrm{~min}$ with crystal violet solution $(0.5 \%$ crystal violet, $10 \%$ ethanol, and $1 \%$ paraformaldehyde) and washed with water. Viral plaques were counted and plaque number was multiplied by the reciprocal of sample dilution. Data are represented as Log10 of the previous obtained plaque number.

\section{Lung characterization}

Lungs were collected in RPMI, cut into small pieces, and enzyme digested with Liberase TM (Sigma-Aldrich) for $30 \mathrm{~min}$ at $37^{\circ} \mathrm{C}$. Cells were passed through a $70 \mu \mathrm{m}$ cell strainer (Falcon) and washed with flow cytometry buffer. After red blood cell lysis, cells were centrifuged, resuspended in cold flow cytometry buffer and stained for flow cytometry analysis.

\section{Trained Immunity in vitro models}

\section{Human Monocytes}

Plated human monocytes were stimulated at day 0 with MV130 (2X10 ${ }^{4}$ bacteria/well) or Excipient in a final volume of $200 \mu \mathrm{L}$ for 24 hours, washed with RPMI 1640 and rested 6 days. On day 7, cells were washed again and further stimulated with $1 \mu \mathrm{g} / \mathrm{mL}$ LPS for 24 hours and supernatants were collected for TNF- $\alpha$ and IL- 6 measurement by ELISA. When required, cells were pre-treated with the epigenetic inhibitors MTA $(1 \mathrm{mM})$ or pargyline $(3 \mu \mathrm{M}) 60$ minutes prior to MV130/excipient stimulation. To explore the metabolic status of the cells, after the challenge with MV130 or excipient, supernatants were collected at days 1 and 7 before LPS stimulation and 
lactate concentration was determined.

\section{BMDM}

BMDM, obtained as previously described from MV130 or excipient pretreated mice, were plated in equal number $\left(10^{5}\right.$ cells per well) in $96-$ well plates $(200-\mu l$ final volume, Corning) and rested overnight. Then, cells were primed with $25 \mathrm{ng} / \mathrm{ml} \mathrm{IFNY}$ (BD Biosciences, San Jose, CA) for 24h. After that cells were washed and stimulated with R10 or $1 \mu \mathrm{g} / \mathrm{ml}$ check Escherichia coli LPS (EK, Invivogen, San Diego, CA) for $24 \mathrm{~h}$. Supernatants were subsequently collected for TNF $\alpha$ measurement by ELISA (Opteia ELISA kit, BD Biosciences).

\section{Antibodies and Flow cytometry analysis}

Stainings were performed at $4^{\circ} \mathrm{C}$ with the appropriate antibody $(\mathrm{Ab})$ cocktail in cold flow cytometry buffer containing 3\% FBS and 0.05\% EDTA. Samples were processed with a LSRFortessa SORP (Becton Dickinson) or a FACS Aria Fusion (Becton Dickinson) flow cytometry equipment and data were analyzed with FlowJo software (Tree Star). CD16/CD32 (TONBO bioscience, San Diego, CA) was used to reduce non-specific binding. The following Abs were used for the analysis of lung immune cell populations: anti-CD45-APC, anti-CD11b-FITC, anti-Ly6G-PE, anti-Ly6C- PerCP-Cy 5.5, for Neutrophils and Monocytes; anti-CD45-V450, anti-MHCII-FITC, anti-CD11b-Pe-CY7, anti-CD11c-PerCP-Cy 5.5, anti-SiglecF-APC for Dendritic cells and Macrophages; anti-CD45-APC, anti-CD3-FITC, anti-NK1.1-PE, anti-CD4-Pe-Cy7, anti-CD8-V450 for T lymphocytes and NK cells; anti-CD45-V450, anti-CD25-APC, anti-CD4-PE and finally anti-FoxP3-FITC following manufacturer instructions for the analysis of T regulatory cells. When required Hoechst 33258 (Invitrogen) was used at $0.1 \mu \mathrm{M}$ as a counterstain to exclude dead cells.

\section{Elisa and Lactate assay}

TNFa measurement by ELISA (Human TNFa DuoSet, R\&D Systems)

IL6 measurement by ELISA (Human IL-6 DuoSet ELISA R\&D Systems)

TNFa measurement by ELISA (Mouse TNFa , BD OptEIA)

Lactate measurement by Lactate assay kit (Sigma)

\section{Statistical analysis}


Prism (GraphPad Software) was used for statistical analysis. In the experimental models, differences in weight loss between MV130 and excipient groups were compared using a two-way ANOVA test, survival curves were compared with Log-rank (Mantel-Cox) test, lung viral loads using an unpaired Student's t test and in vitro experiments using a paired student's test, since the variables followed a normal distribution. Other statistical tests are detailed in figure legends. p-values: ${ }^{*} p<0.05 ; * * p 0.01 ; * * p<0.001$. 

RESULTS
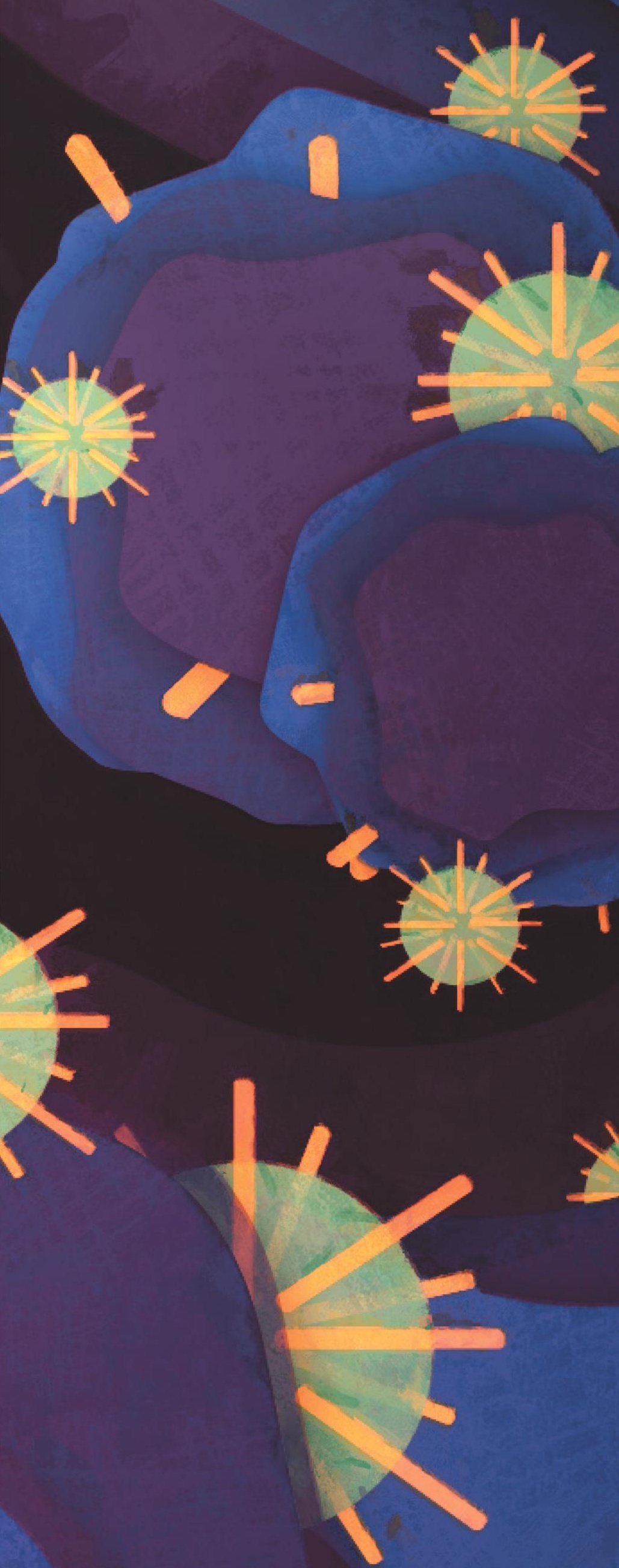

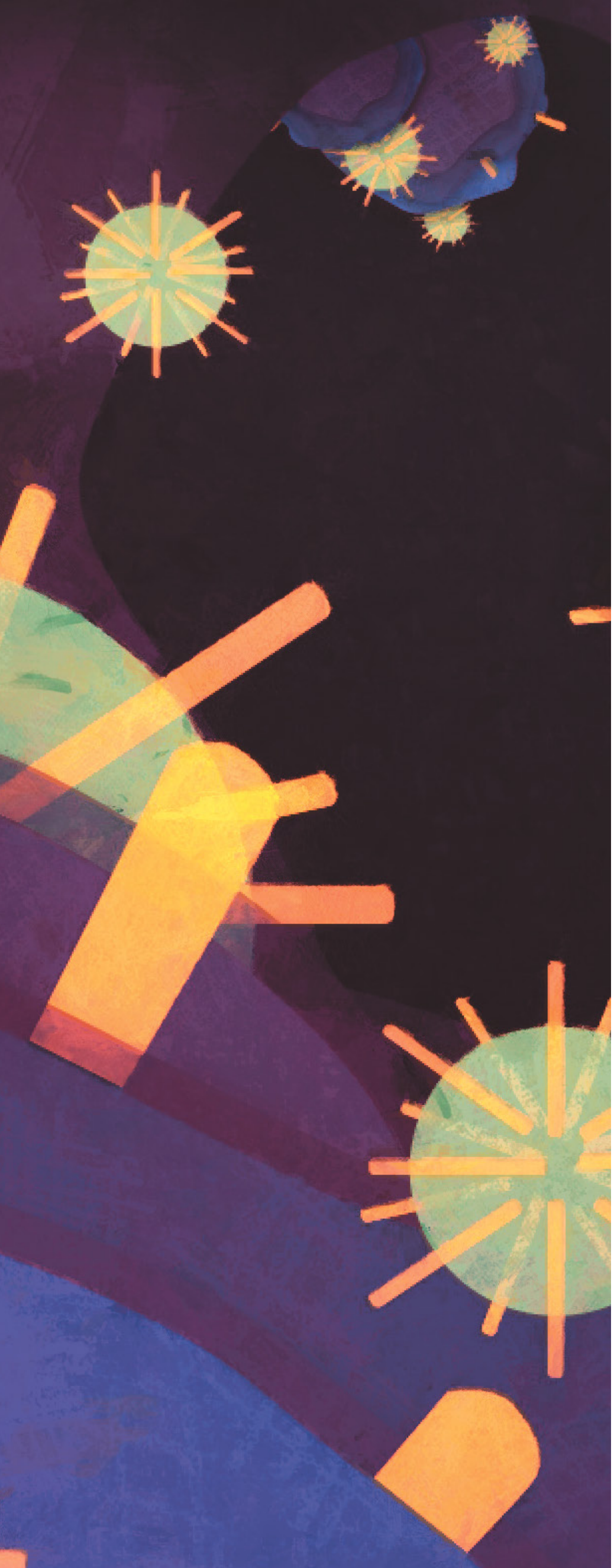


\section{Results}

\section{Role of MV130 in the protection against viral respiratory infections}

V130 is a polyvalent bacterial preparation that has been shown to be effective in
preventing recurrent respiratory infections, including some of viral origin ${ }^{43}$. Mo-
reover, a phase 3 randomized, double-blind, placebo-controlled, parallel-group trial, performed by A. Nieto and collaborators showed that children under 3 years old who had suffered more than three WA, when treated with MV130 presented a significant reduction in the frequency and severity of wheezing episodes. Importantly most wheezing episodes in young children have a viral etiology and are associated mainly with rhinovirus and RSV ${ }^{91}$. In addition, it is known that MV130 is able to immunomodulate the function of DCs promoting a potent proinflammatory response, inducing the secretion of cytokines to bias toward Th1 and Th17 responses. On the other hand, MV130 also induces the production of high levels of IL-10 by DCs and the generation of IL-10-producing T cells which is essential to avoid excessive deleterious responses ${ }^{44}$.

However, the mechanism of action by which MV130 confers immune protection is still unknown. 


\subsection{MV130 protects against Vaccinia virus respiratory infection in mice}

To gain insight into the potential resistance to viral infection conferred by MV130, we designed an in vivo experimental approach trying to mimic human respiratory infections in mice ${ }^{43}$. Mice were treated three times a week for three consecutive weeks with MV130 or its control that we will refer to as excipient. Since MV130 is administered in humans as a mucosal vaccine, we tested two different types of mucosal immunization in mice. Precisely, we administered MV130 through both s.l. and intranasal (i.n.) route. One week after the last challenge with MV130 or excipient, mice were i.n. infected with Vaccinia virus (VACV). To follow the course of the infection we monitored the weight loss, a clinical score in murine infection models (Figure R1A). We did not observe any difference in weight loss between mice treated with MV130 or excipient when treatment was sublingually administered (Figure R1B). However, when the route of administration was i.n., animals treated with MV130 showed less weight loss compared to the control group, upon VACV infection (Figure R1C). This result indicates that i.n. administration of MV130 confers protection against VACV infection, and on that basis, we opted for the i.n. route of administration to evaluate MV130-mediated protection against lung viral infections.

A

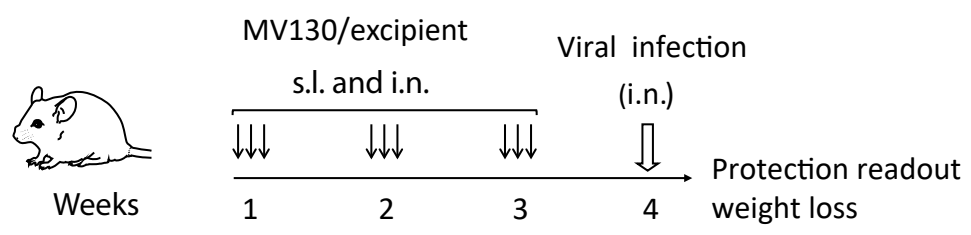

B

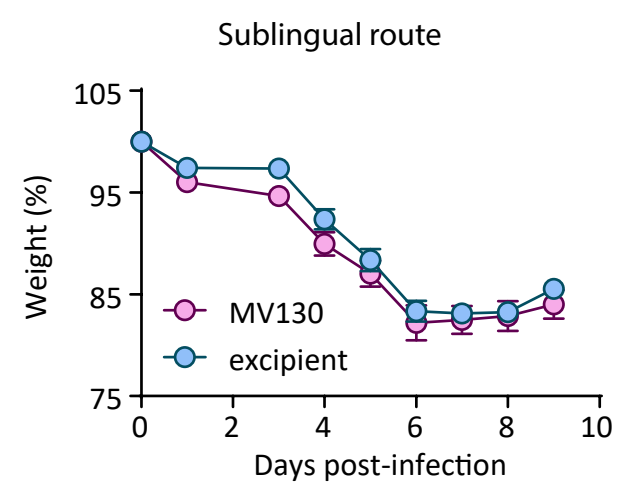

C

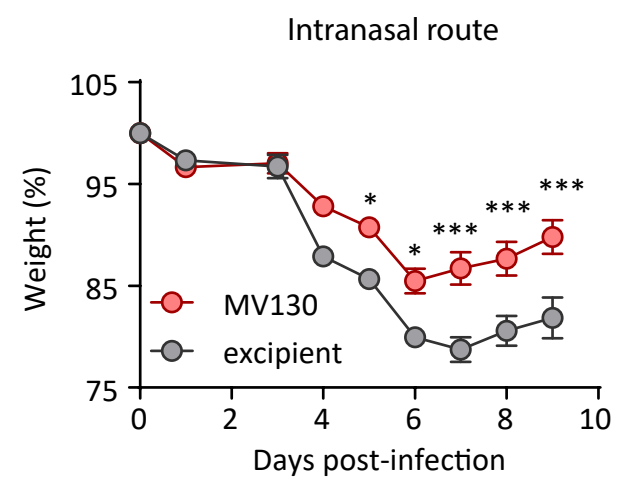

Figure R1. The protective effect of MV130 against VACV infection depending on the administration route. (A) Graphical outline of the in vivo models of MV130 treatment followed by i.n. infection with VACV. C57BL/6 mice were treated three times a week for three consecutive weeks with MV130 or excipient through s.I. (B) or i.n. (C) route and infected i.n. 7 days later 
with VACV $\left(5 \times 10^{4}\right.$ plaque forming units [PFU]). Weights were recorded daily and mean \pm SEM represented ( $B$ and $C$ ). Representative result from 2 independent experiments is shown. Weights were compared using a two-way ANOVA test. ${ }^{*} \mathrm{P}<0.05 ;{ }^{* * *} \mathrm{P}<0.001$.

\subsection{Intranasal vaccination with MV130 results in reduced VACV viral load in the lung}

Next, we aimed to explain the differences in the weight loss that appear by day 4 post VACV infection between MV130 treated and control mice (Figure R1B). For that, we evaluated the viral load titers in the lung just three days post VACV infection in mice pre-treated or not with MV130. A lower viral load titer was present in the lungs of mice that were pretreated with MV130 (Figure $\mathrm{R} 2)$, confirming its protective role.

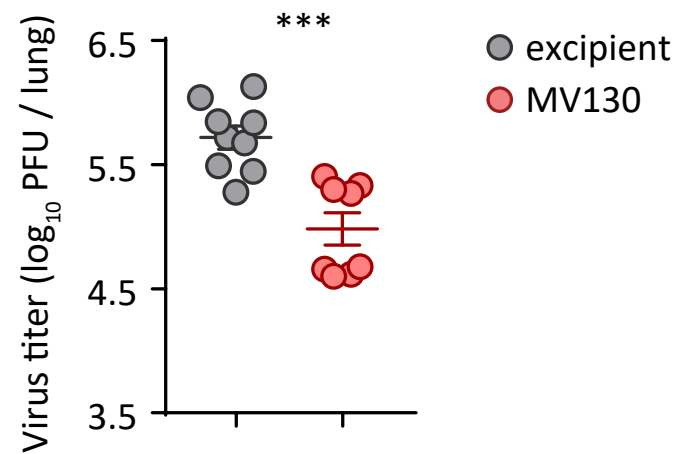

Figure R2. Reduction of lung viral titer upon MV130 treatment. C57BL/6 mice were treated three times a week for three consecutive weeks with MV130 or excipient i.n. and infected seven days later with VACV ( $\left.5 \times 10^{4} \mathrm{PFU}\right)$ i.n. Lung viral loads were analyzed on day 3 post-infection by plaque assay. Individual data and the mean \pm SEM are represented. Results from a pool of 2 independent experiments are shown. Lung viral titers were compared using an unpaired student's t test. ${ }^{* * *} \mathrm{P}<0.001$.

\section{Effects of MV130 on lung immune cells at different time points}

\subsection{MV130 affects the expansion of both myeloid and lymphoid populations}

To further explore the effects of MV130 treatment in the lung, we characterized the immune cell compartment in the lung and quantified the absolute number of different immune cell po- 
A

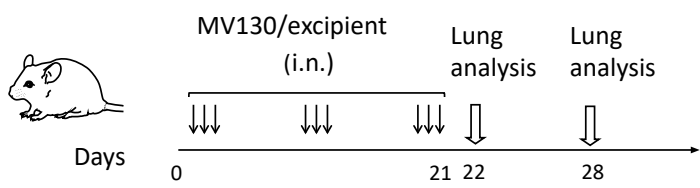

B
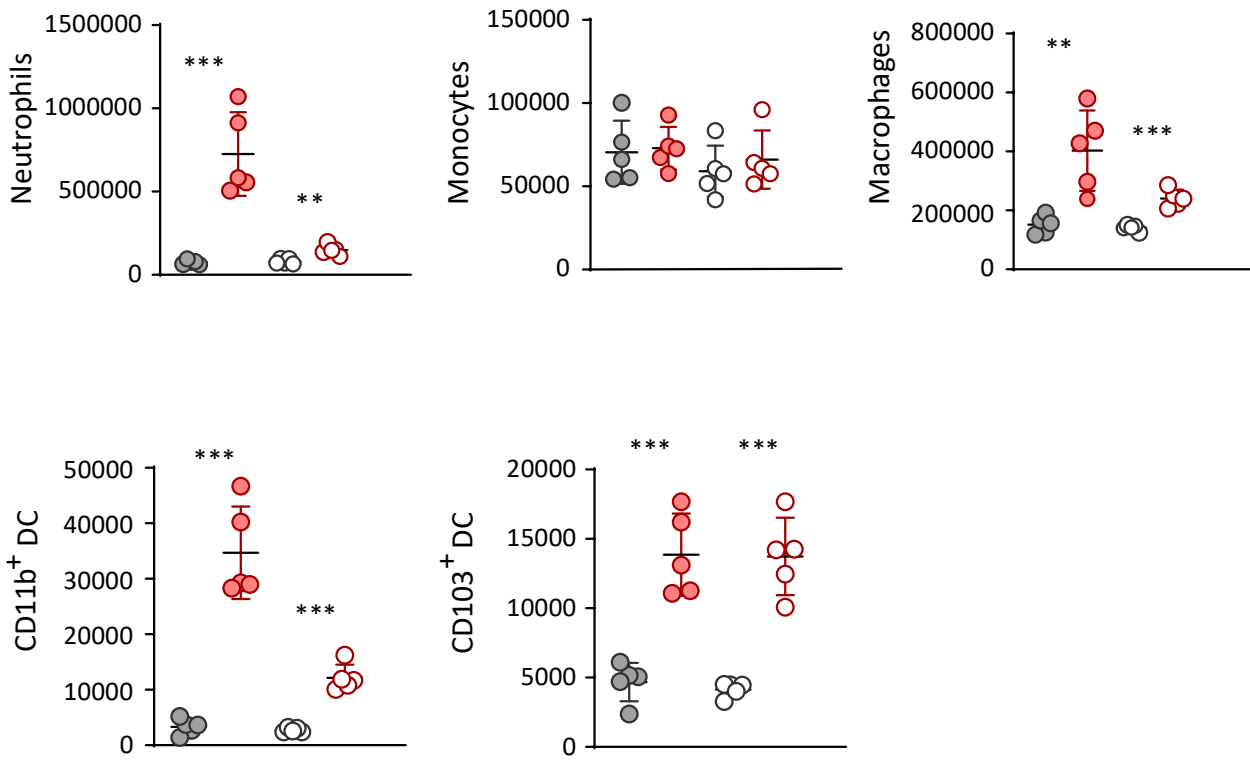

O Day1 excipient

O Day1 MV130

O Day7 excipient

O Day7 MV130

C
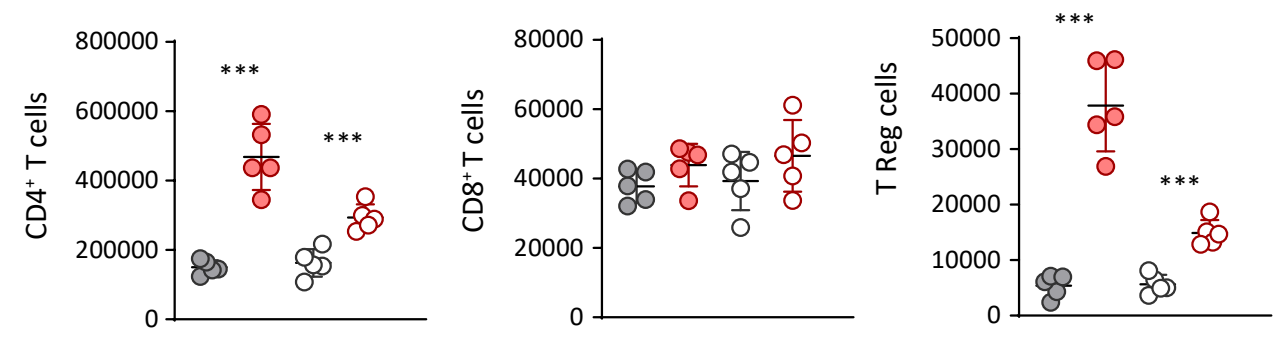

○ Day1 excipient

O Day1 MV130

O Day7 excipient

O Day7 MV130

Figure R3. Characterization of lung immune cells upon MV130 treatment. (A) Graphical outline of the in vivo model of MV130 treatment followed by lung analysis at two different time points. C57BL/6 mice were treated three times a week for three consecutive weeks with MV130 or excipient i.n. Lung immune cells were analyzed by flow cytometry on day 1 (B) and 7 (C) after the last MV130 challenge. Individual data and the mean \pm SEM were represented. Representative result from 2 independent experiments is shown. Lung immune cells were compared using an unpaired student's t test between excipient and MV130 in the same time point. ${ }^{* *} \mathrm{P}<0.01 ;{ }^{* * *} \mathrm{P}<0.001$. 
pulations one day and one week after the last challenge with MV130 (Figure R3A). One day after the last dose of MV130 there was an increase of both myeloid (Figure R3B) and lymphoid (Figure R3C) immune cell populations. In particular neutrophils, macrophages and both CD11 $\mathrm{b}^{+}$ and $\mathrm{CD} 103^{+} \mathrm{DCs}$, were expanded in the myeloid compartment. On the other hand, while there was no difference in the number of $\mathrm{CD}^{+} \mathrm{T}$ cells infiltrating the lung, we observed an increase in the number of $\mathrm{CD}^{+} \mathrm{T}$ cells in the lung of mice treated with MV130, particularly of T regulatory cells (Tregs). These differences in immune cell populations were maintained seven days after the last challenge with MV130, although the magnitude of the change was milder and numbers of the different cell populations in MV130-treated mice were closer to basal levels. Interestingly, only for $\mathrm{CD}_{103^{+}} \mathrm{DCs}$ we detected the same number of cells after one day and seven days post-challenge with MV130. Taken together MV130 affects the infiltration of both myeloid and lymphoid populations in the lung, although $\mathrm{CD} 103^{+} \mathrm{DC}$ display a more stable increase.

\section{MV130 protects against Influenza virus infection}

To confirm the protective role of MV130 against antigenically unrelated viral infections, we reproduced the previously described strategy (Figure R4A), but we infected mice with Influenza A/ Puerto Rico/8/1934 (H1N1) (PR8) virus. This is a more clinical relevant model as Influenza virus infection in humans often results in a respiratory disease that ranges in severity from sub-clinical infection to primary viral pneumonia ${ }^{92}$. Moreover Influenza is a common pathogen identified in children with acute lower respiratory infections (ALRI) and results in a substantial burden on health services worldwide ${ }^{93}$. We show that pretreatment with MV130 also reduces morbidity and mortality in an animal model of Influenza A virus infection (Figure R4B-C). This result suggests that MV130-mediated protection is not specific for VACV infection but could be extended to a wide range of viruses. 
A

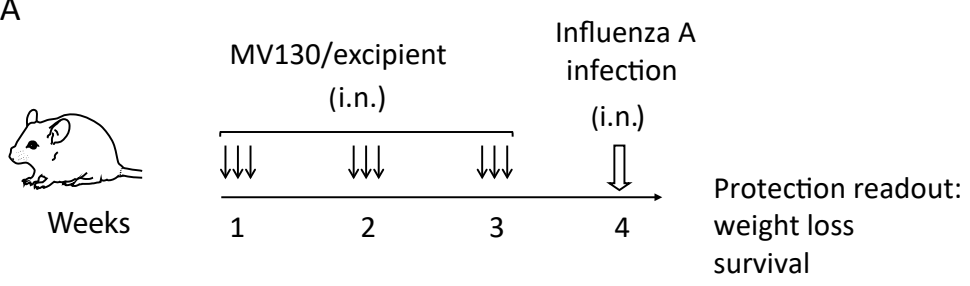

B

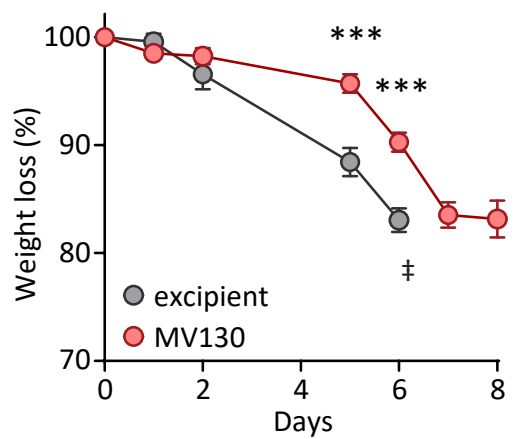

C 
show that the protection conferred by MV130 appears very early after viral infection. Differences in weight loss between control mice and MV130 challenged mice start to appear just four days after intranasal administration of both VACV and Influenza A virus. Also the lung viral load is found to be reduced in mice pretreated with MV130 at day 3 post VACV infection. Moreover beneficial effects promoted by our polyvalent bacterial preparation are due to non-specific response against antigenically unrelated pathogens. Taken together we hypothesized that MV130 mediated protection did not rely on adaptive immune system. Finally, as the protective effect conferred by MV130 against viral infections was maintained along the time, during at least one week, the induction of trained immunity, as a potential mechanism of action, was assessed.

\subsection{Mice intranasally challenged with MV130 are protected against systemic Candida albicans infection}

Trained immunity is defined as memory of the innate immune system, where innate immune cells exposed to a first stimulus are able to mount an enhanced non-specific response against a secondary related or unrelated challenge thus providing long-term protection in case of infection ${ }^{50,52}$. To address the induction of this phenomenon by MV130 in vivo, we tested its protective effect against systemic Candida albicans infection. We treated mice i.n. twice with MV130 or excipient, and four days after the last challenge we intravenously (i.v.) infected them with C. albicans (Figure R5A), following the strategy that is considered the gold-standard of trained immunity ${ }^{51}$. As shown in Figure R5B, i.n. treatment with MV130 resulted in reduced mortality following $C$. albicans infection, further confirming the ability of MV130 to induce heterologous protection. Importantly this protection is not restricted to the administration route of the infectious stimulus as, unlike viral infection, C. albicans was injected intravenously, showing that MV130 is able to confer also systemic protection.

\subsection{MV130-mediated protection against systemic C. albicans infection in mice is not dependent on adaptive immune system}

Trained immunity is defined by specific characteristics. Among them there is the ability to confer protection without the involvement of the adaptive immunity, as demonstrated by studies performed on mice lacking $B$ and T cells ${ }^{51,53,54}$. To ascertain whether immune protection mediated by MV130 was due to enhanced response of the innate immune system, we performed the in vivo experiment previously described (Figure R5A) in Rag1 ${ }^{-}$mice that lack mature $\mathrm{B}$ and $\mathrm{T}$ 
lymphocytes. As shown in Figure R5C, mice pretreated i.n. with M130 display increased survival compared to excipient-treated controls following C. albicans i.v. infection. This result supports the notion that MV130-mediated protection is systemic and additionally demonstrates that it does not involve the adaptive immune system.

A

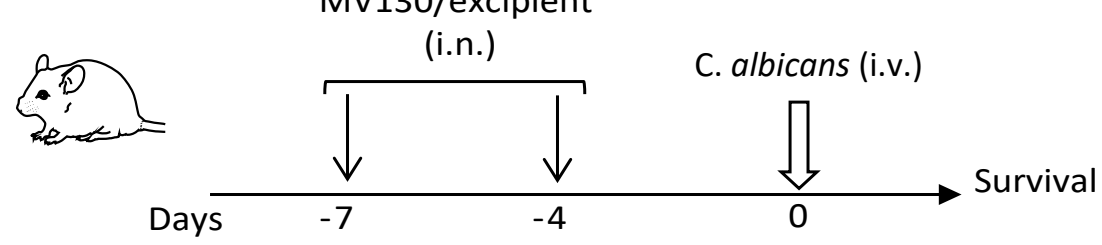

B

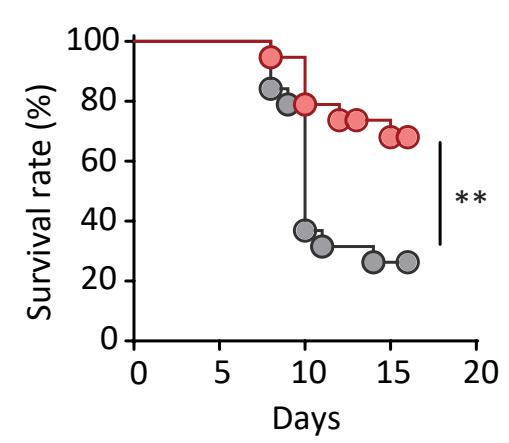

C $\quad$ Rag1 ${ }^{-} /$mice

O excipient

O MV130

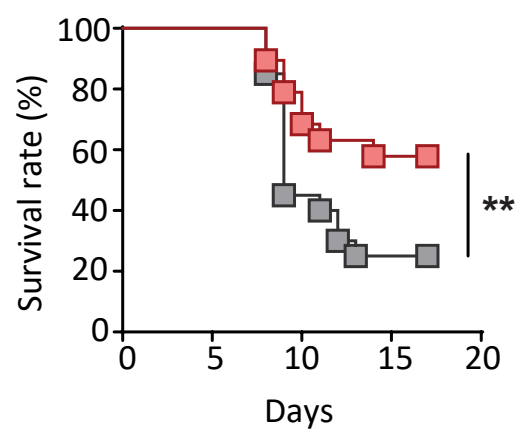

$\square$ excipient

MV130

Figure R5. MV130 protection against C. albicans infection is B and T cell independent. (A) Graphical outline of the in vivo trained immunity protection model with C. albicans. C57BL/6 mice were treated twice with MV130 or excipient i.n and infected i.v. with C. albicans. Mice survival was monitored. Survival rate of wild-type C57BL/6 (B) or Rag1\% (C) mice infected with $3 \times 10^{5}$ (B) or $1.5 \times 10^{5}$ (C) C. albicans, respectively, following treatment with MV130 or excipient. Survival curves were compared with Log-rank (Mantel-Cox) test. ${ }^{* *} P<0.01$

\section{MV130 educates myeloid progenitors promoting their differentiation into trained mature cells.}

It has been described that trained immunity acts via modulation of hematopoietic stem and progenitor cells and this is translated into functional changes of mature myeloid cells in the periphery ${ }^{89,92}$. In this regard, we hypothesized that MV130 would be able to confer systemic protection through education of myeloid precursors. 


\subsection{Bone marrow derived macrophages from mice treated in vivo with MV130 show higher TNF $\alpha$ production in response to LPS}

In order to confirm our hypothesis, we designed a strategy based on a previously published scheme ${ }^{92}$. We treated animals for three weeks with MV130 or excipient and after one week of rest we collected bone marrow to generate bone marrow derived macrophages (BMDM).

Once differentiated, macrophages were counted and plated in equal numbers to be subsequently challenged for 24 hours with Lipopolysaccharide (LPS), a toll like receptor 4 (TLR4) agonist found in gram negative bacteria. TNF $\alpha$, a hallmark trained immunity cytokine ${ }^{61}$ was measured in the culture supernatants (Figure R6A). As shown in Figure R6B, BMDMs generated from MV130 pre-treated mice produced higher levels of TNF $\alpha$ than those derived from excipient-treated mice. This would suggest that immune training by MV130 might occur through a mechanism that involves education of myeloid progenitors.

A

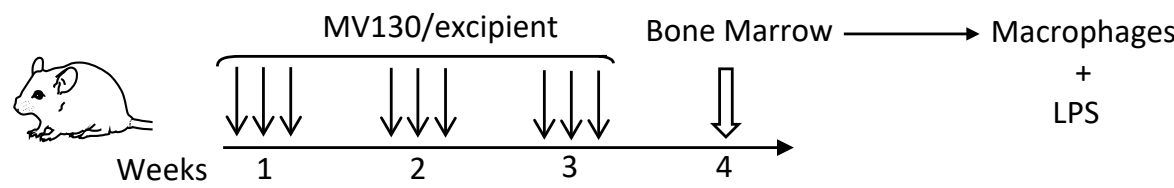

B

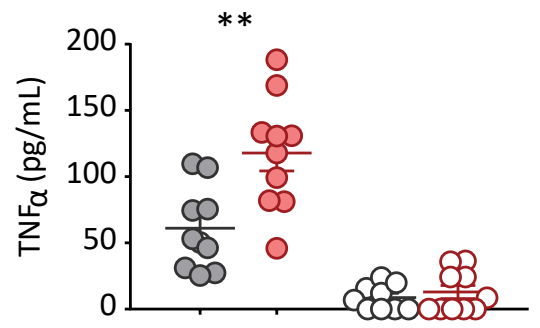

excipient

MV130

Ctrl excipient

C Ctrl MV130

Figure R6. MV130 and myeloid progenitors reprogramming. (A) Graphical outline of the in vivo model of MV130 treatment followed by analysis of myeloid progenitors "reprogramming". Wild-type C57BL/6 mice were treated i.n. with MV130 or excipient and after seven days of resting, bone marrow was collected. Cells were differentiated into BMDMs in presence of $L 929$ supernatant. After 5 days, differentiated BMDM were subsequently plated in equal cell number and treated with LPS for 24 hours. TNF $\alpha$ was measured in the cell supernatant by ELISA (B) Individual data and the mean \pm SEM were represented. Results from a pool of 2 independent experiments are shown. TNFa levels were compared using an unpaired student's t test. $* * P<0.01$. 


\section{6. mTOR pathway involvement in the MV130-mediated protection}

It has been described that mammalian mTOR plays an important role in trained immunity as its inhibition through metformin completely abrogates the protection conferred by $\beta$-glucan both in vitro and in vivo ${ }^{71}$.

\subsection{Metformin treatment significantly reduces MV130-mediated protection against Influenza virus respiratory infection}

In order to confirm that MV130-mediated protection against viral infections relies on trained immunity, mice received metformin from one day before the first MV130 challenge until three days after the last one following the scheme shown in Figure R7A. After that, mice were infected with Influenza A virus. To avoid treating animals with metformin for a long time period, we administered MV130 and excipient to the mice for only two weeks. As shown in Figure R7B-C this change did not affect the ability of the polyvalent bacterial preparation to confer protection. However, pretreatment with metformin impaired MV130-mediated protection against Influenza A infection, in terms of both weight loss and survival, suggesting the involvement of the mTOR pathway in the mechanism of action of MV130. As it has been described that $\beta$-glucan-mediated training is based on the activation of the mTOR/HIF1 $\alpha / A k t$ pathway, this result strengthens the hypothesis that MV130 mediates cross-protection through a trained immunity-mediated mechanism.

A

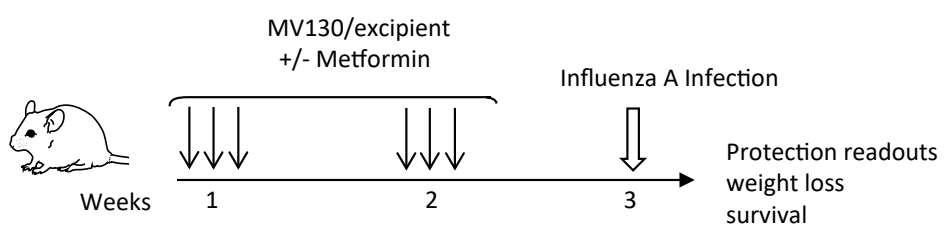

B

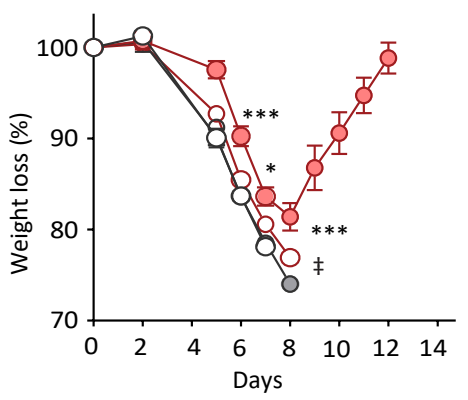

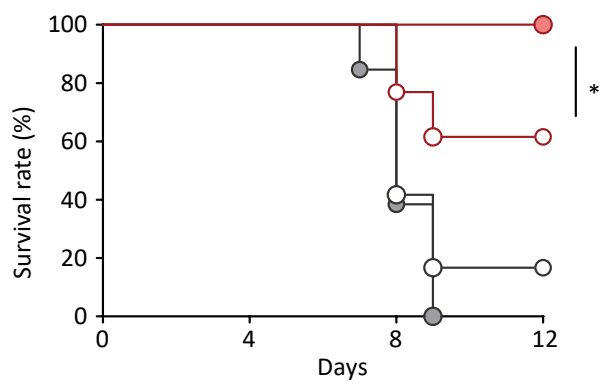

$$
\begin{array}{ll}
\text {-O MV130 } & \text {-o- excipient } \\
\text {-o- MV130+Metformin } & \text {-O- excipient+Metformin }
\end{array}
$$


Figure R7. MV130 mediated protection involves mTOR pathway. (A) Graphical outline of in vivo treatment with metformin in mice immunized with MV130 and subsequently chaIlenged with Influenza A Wild-type C57BL/6 received metformin ad libitum in drinking water from one day before the first MV130/excipient challenge to four days after the last immunization dose. Mice were challenged seven days later with Influenza A, weights recorded daily and mean \pm SEM represented (B-C). $¥$ Indicates that excipient, and metformin + excipient and metformin + MV130 groups had to be excluded from the graph from day 7 and 8, respectively, due to mouse mortality. Results from a pool of 2 independent experiments are shown. Survival curves were compared with Log-rank (Mantel-Cox) test (C). Weights were compared using a two-way ANOVA test. ${ }^{*} \mathrm{P}<0.05$ and ${ }^{* * *} \mathrm{P}<0.001$, comparing MV130 and metformin + MV130 groups (B).

\section{MV130 trains human monocytes in vitro}

To ascertain if MV130 mechanism of action in humans also involved the induction of trained immunity, we tested whether MV130 could induce trained immunity in human monocytes. To evaluate this, we assessed the three hallmarks that characterize trained immunity: increased cytokine production upon rechallenge, epigenetic reprogramming and changes in the cellular metabolic landscape of innate immune cells ${ }^{72,73}$.

\subsection{MV130 promotes increased cytokine production by human monocytes in vitro and its effect relies on epigenetic changes}

To evaluate whether the immune training capacity of MV130 might also take place in humans, human monocytes were obtained from buffy coats from healthy donors and were tested in a well-established trained immunity in vitro model ${ }^{51}$. After the first challenge with MV130 or excipient, human monocytes were washed and rested in complete medium for six days (Figure R8A). Next, monocytes were stimulated with LPS for one day, and trained immunity associated cytokines such as TNF-alpha and IL-6 were measured in the cell culture supernatant. In addition, to evaluate if MV130 epigenetic reprograming could be taking place after MV130 treatment, monocytes were treated with epigenetic inhibitors 60 minutes before the first challenge with MV130. Specifically, we used 5'-deoxy-5'-(methylthio)adenosine (MTA), a methyltransferase in- 
hibitor that has been described to prevent training induction, and pargyline, a demethylase inhibitor which has no effects in the training process ${ }^{51}$. As shown in Figure R8B-C, pretreatment with MV130 led to increased TNF $\alpha$ and IL-6 production in response to LPS, compared with the excipient-treated monocytes. This enhanced response is lost in presence of MTA, but preserved with pargyline. These results highlight the role of MV130 in inducing trained immunity upon epigenetic reprogramming.

\subsection{MV130 promotes increased lactate production in supernatants from human monocytes}

As described above, trained immunity is also associated with changes in the metabolic pathways used by the cells. The main change in cellular metabolism during the induction of $\beta$-glucan- ${ }^{71}$ or BCG-mediated trained immunity ${ }^{95}$ consists of a shift from oxidative phosphorylation (OXPHOS) to aerobic glycolysis (Warburg effect). In particular it has been described that $\beta$-glucan trained monocytes show reduced oxygen consumption, increased glucose uptake and elevated lactate production on day 7 post-training ${ }^{71,95}$. With the aim to evaluate whether MV130 would be able to induce this metabolic switch to glycolysis, we measured lactate levels in the supernatant from human monocytes, at day 1 and at day 7 after MV130 priming. As shown in Figure R8D-E, MV130-treated monocytes show an increase in the production of lactate both at day 1 and 7 after MV130 stimulation, which correlates with increased glycolytic metabolism. 
A

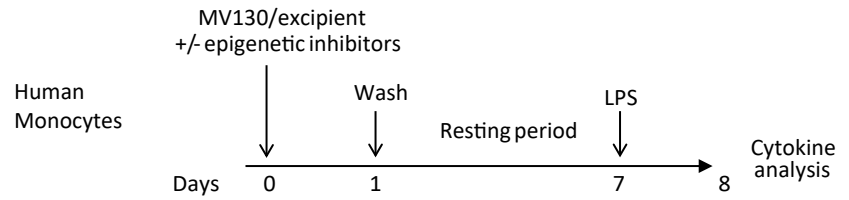

B

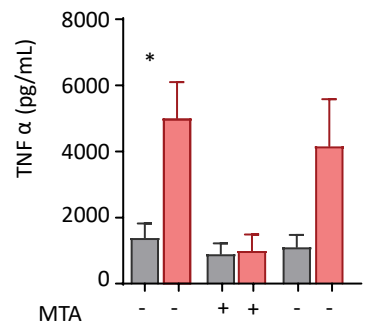

Pargyline

Lactate day 1

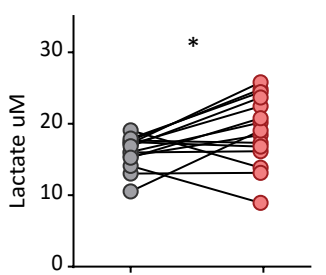

C

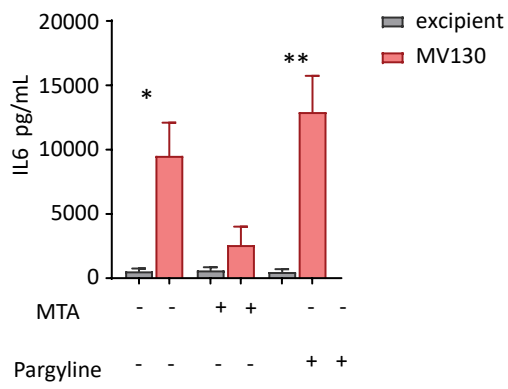

Lactate day 4

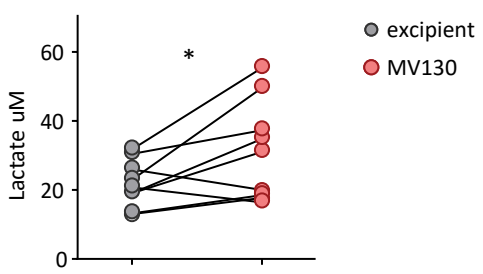

Figure R8. MV130 induces trained immunity in human monocytes. (A) Graphical outline of the in vitro trained immunity model. Plated human monocytes were incubated for 24 hours with excipient or MV130, with or without MTA or pargyline for 30 minutes prior to MV130 or excipient stimulation. Then, cells were washed and rested for six days. At day 7, cells were stimulated with LPS for 24 hours and TNF- $\alpha$ and IL- 6 were determined in the supernatant by ELISA. Mean + SEM of 5 independent donors is shown (B-C). Plated human monocytes were incubated with excipient or MV130 and supernatants collected after 24 hours (D) or seven days (E) to measure lactate production/release. Each dot represents an individual experiment of 15 (D) and 9 (E) independent donors. $P$ values for in vitro experiments were calculated using a paired student's t test comparing the different groups. ${ }^{*} P<0.05 ;{ }^{* *} P<0.01$ 



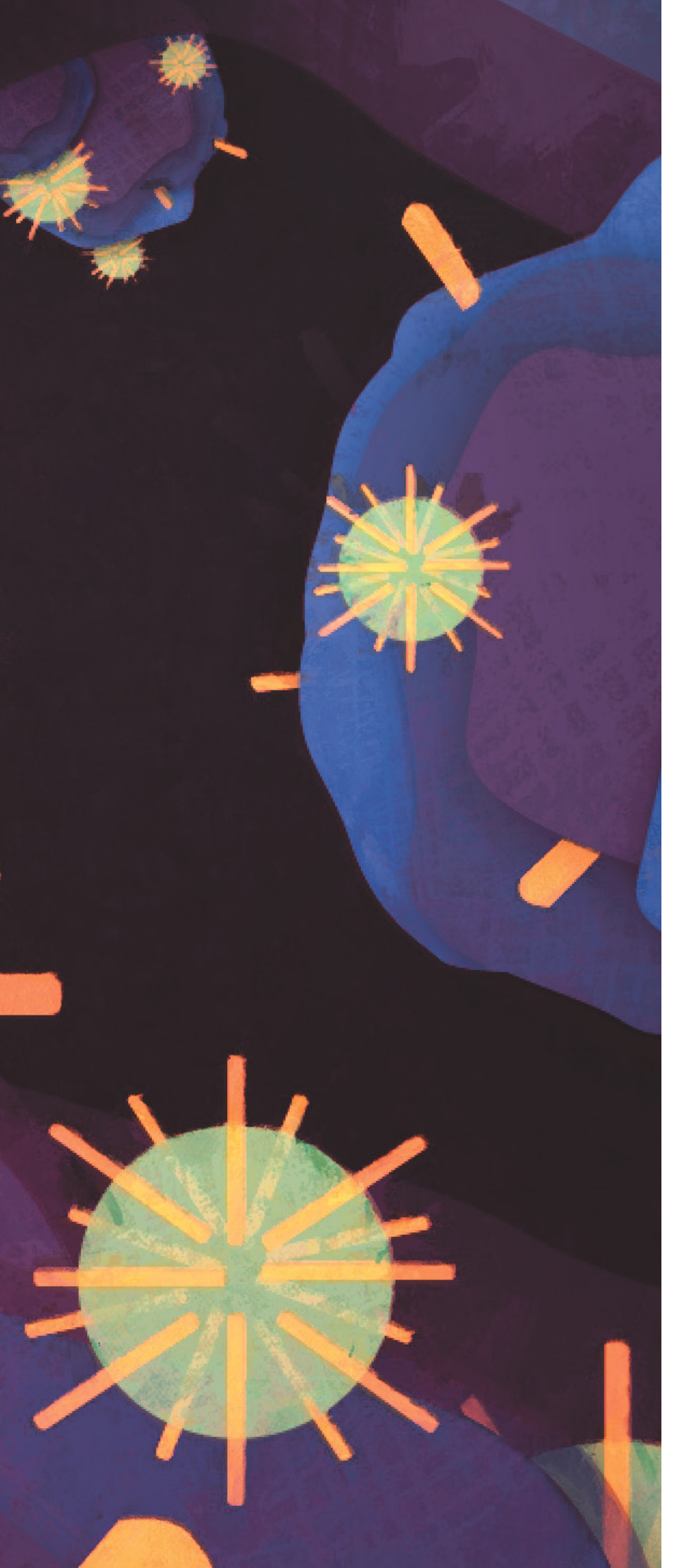




\section{Discussion}

his thesis aims to investigate the mechanism of action of polyvalent bacterial vacci-
ne MV130 that in humans confers protection against RRTI and WA. We found that
MV130 is able to induce early and non-specific protection in experimental models of viral respiratory infection, suggesting induction of innate immune training. Using a well-established in vivo model of trained immunity, we show that MV130 protects against a systemic sublethal dose of $C$. albicans infection in the absence of T and B lymphocytes. Furthermore, the protection achieved by MV130 against Influenza A infection is prevented by metformin, which inhibits the mTOR pathway and thus impairs trained immunity. We also show that MV130 is able to educate myeloid precursors, generating in vitro macrophages with enhanced pro-inflammatory capacities. Finally, MV130 is able to induce trained immunity in human monocytes, promoting metabolic changes and enhanced cytokines production depending on epigenetic modulation (Figure D1). 

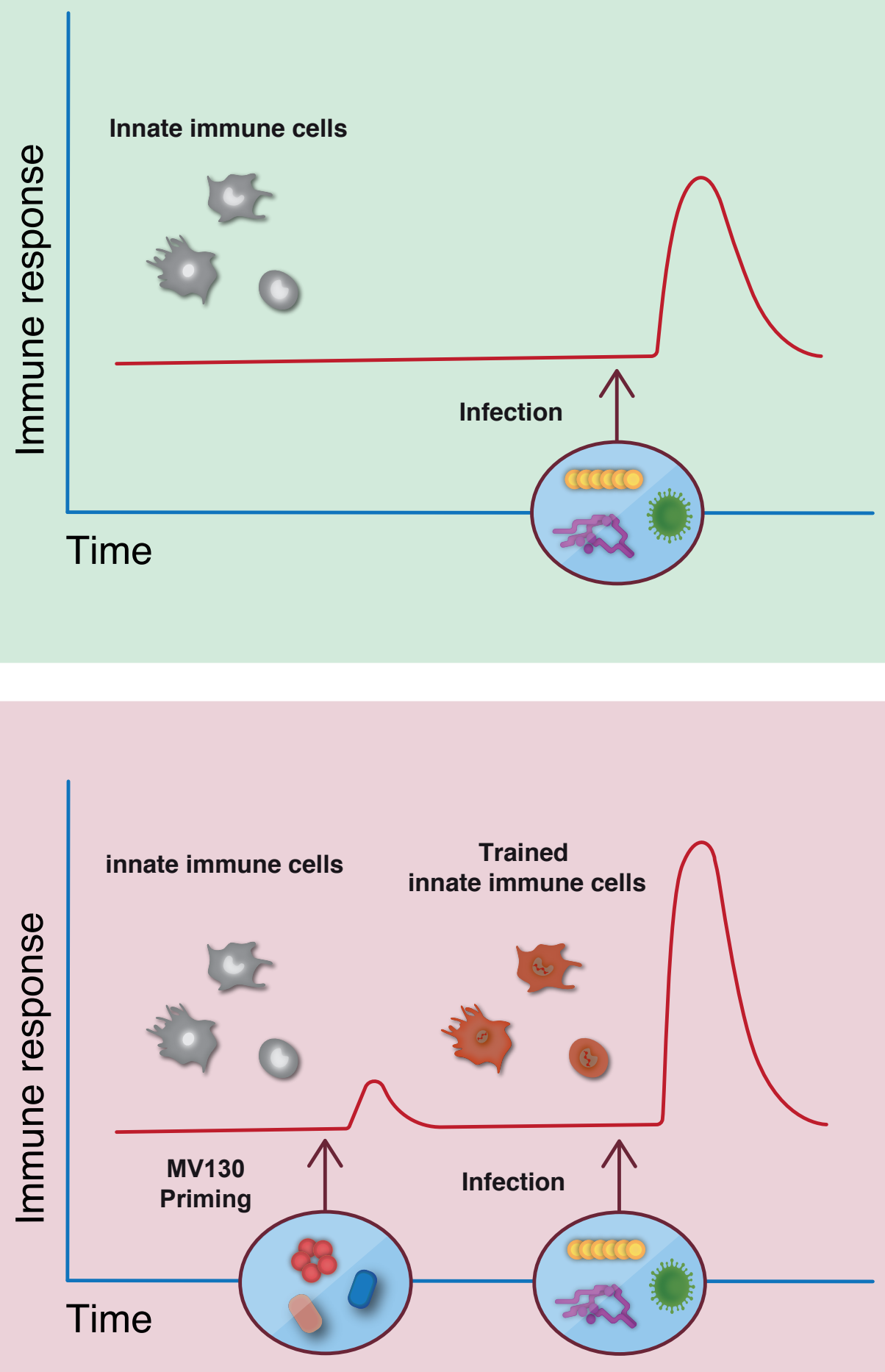

Figure D1. Working model for the protection conferred by MV130: MV130 acts as a trained immunity inducer. Innate immune cells primed with MV130 undergo long-lasting changes, including epigenetic and metabolic reprogramming, and acquire ability to promote enhanced response against secondary related or unrelated infections. 


\section{MV130 protects against viral respiratory infections}

A prospective open pilot study in a cohort of patients with RRTIs showed that upon MV130 treatment the rate of infections was significantly decreased. RRTIs were considered as including episodes of rhinitis, pharyngitis, tonsillitis, otitis, sinusitis, bronchitis, and pneumonia each of them defined by the presence of diagnostic symptoms for at least $48-72$ hours. Also viral infections defined as colds and herpes, were taken into account ${ }^{43}$. The protective role of MV130 in respiratory diseases is confirmed in the phase 3 randomized clinical trial, performed by doctor A. Nieto and collaborators, in which, children under age of 3, upon treatment with MV130 showed an important reduction in the frequency and severity of WA (A. Nieto and P. Brandi unpublished data). It's known that the majority of wheezing episodes in young children have a viral etiology ${ }^{91}$. However there are no experimental data that directly demonstrate the ability of MV130 to protect against viral respiratory infections. For this purpose, we designed an in vivo experimental approach using murine models. We show that sublingual administration of MV130 does not confer protection against VACV i.n. infection. This result could appear in disagreement with the fact that in humans MV130 is administered through the s.l. route. However there are studies claiming that mice present a different mucosal architecture when compared to humans and this factor has to be considered in studies of biodistribution analysis ${ }^{96}$. Moreover the mechanisms underlying the efficacy of s.l. immunotherapy in humans have been associated to the Waldeyer's ring that has the function of producing antibodies toward the common environmental antigens and includes adenoids, tubal tonsil, palatine tonsil, and lingual tonsil ${ }^{97}$. Although mice do not possess tonsils, their functional equivalent is represented by the nasal-associated lymphoid tissue ${ }^{98}$. In line with this, administration of MV130 through i.n. route in mice confers protection against both VACV and Influenza A virus mediated respiratory infections.

The protective effects of polybacterial preparations were already shown in a previous study demonstrating that the orally administered bacterial extract OM-85, protected mice against Influenza A infection ${ }^{99}$. However, in that case, the mechanistic rationale behind the use of the orally administered bacterial extract for the prevention of respiratory infections relied on the gut-lung immune axis. Accumulating evidence has highlighted the influence of the gut microbiota on lung immunity although the underlying pathways and mechanisms are still areas of intensive research ${ }^{100,101}$. Trompette et al. recently found that feeding mice a fiber- rich diet chan- 
ged the composition of the lung and gut microbiome, the latter metabolizing the fiber into circulating short-chain fatty acids (SCFA's). The increased SCFA levels protected the mice from allergic lung inflammation. Mechanistically, the SCFA's altered DC precursor generation in the bone marrow, and the DCs subsequently seeding the lungs had a higher phagocytic capacity and were impaired in polarizing Th2 cells ${ }^{38}$. In line with this, further studies are required to determine whether, changing the administration route, the protective effects of MV130 would be conserved. On the other hand it would be interesting to study the ability of MV130 to generate immune responses at distant mucosal tissues. It is known that s.I. and i.n. immunization can induce specific IgA secretion and activation of $C D 8^{+} T$ cells in the genital tract and in some cases in the intestine ${ }^{102,103}$. According to that, a mouse model of cervicovaginal infection caused by Genital human papillomavirus (HPV) ${ }^{104}$ could be used to explore the possible preventive or therapeutic effects of MV130 on infections of the genital tract.

\section{MV130 presents immunomodulatory abilities in the lung compartment}

In order to evaluate the effects of MV130 treatment on lung immune compartment, the absolute number of different cell populations one day and one week after the last challenge with MV130 were quantified. One day after the last dose of MV130 a general expansion of both myeloid and lymphoid compartment was observed. This result is consistent with previous studies showing the effects of other bacterial preparations or bacterial lysates on the immune system ${ }^{31}$. For instance OM-85, obtained by the alkaline lysis of 21 strains of common bacterial respiratory tract pathogens, activated DC to release some cytokines, as IL-6 and B-cell activating factor (BAFF) and polymorphonuclear attracting chemokines such as CXCL8 , CXCL6 and CXCL1 ${ }^{105}$. Also MV130-activated human DCs produced high levels of the pro-inflammatory Th1- (IL-12p70 and TNF- $\alpha$ ) and Th17-driving (IL-6, IL-1 $\beta$, IL-23) cytokines as well as high levels of IL-10 ${ }^{44}$. According to our results about the increasing number of $\mathrm{CD}^{+} \mathrm{T}$ cells, it has been shown that MV130-activated human monocyte derived DCs (hmoDCs) induced a significantly higher percentage of proliferating allogeneic naïve $\mathrm{CD}^{+} \mathrm{T}$ cells than control-treated $\mathrm{hmoDCs}^{44}$. In addition humans treated for six months with MV130 showed a significant increase in the proliferating capacity of the antigen-specific 
memory $\mathrm{CD}^{+} \mathrm{CD}^{+} \mathrm{T}$ cells ${ }^{43}$. We then analyzed the immune cells in the lung seven days after the last challenge with MV130 showing that the magnitude of the change was milder and the numbers of the different cell populations in MV130-treated mice returned closer to the basal levels. Interestingly, only for $\mathrm{CD}_{103^{+}} \mathrm{DCs}$ we detected the same number of cells after one day and seven days post-challenge with MV130. First of all the increased number of CD103 ${ }^{+}$DCs in MV130 treated mice could explain the expansion of Treg cells that are essential for establishment of airway tolerance ${ }^{106,107}$. Although an effective immune response to eliminate viral pathogens is essential during viral infections, a prolonged or exaggerated response can damage the respiratory tract. So the immune system has the important role to balance the virus clearance and a possible immunopathology ${ }^{30}$. On the other hand previous studies show that $\mathrm{CD} 103^{+} \mathrm{DC}$ regulate the magnitude of $\mathrm{CD}^{+} \mathrm{T}$ cell effector responses in the lungs, thereby providing protection during pulmonary VACV infection ${ }^{108}$. Also it has been described that lung migratory $\mathrm{CD} 103^{+} \mathrm{DCs}$ were not infected by influenza virus and thus were able to induce virus-specific $C D 8^{+} T$ cells through the cross-presentation of antigens from virally infected cells. Moreover the enhanced cross-priming ability acquired by migratory lung DCs correlates with an increased anti-viral state in these cells ${ }^{109}$. However whether $\mathrm{CD} 103^{+}$DCs in our model represent the major players involved in the MV130 mediated protection require other different approaches and further investigation.

\section{MV130 mediated protection correlates with trained immunity induction}

The vertebrate immune system has traditionally been defined as the interplay between innate and adaptive branches. The innate immune system is the first line of host defense during infection and for that is considered fast and with limited specificity, playing a crucial role in the early recognition and subsequent triggering of a pro-inflammatory response to invading pathogens. The adaptive immune system, on the other hand, leads to elimination of pathogens in the late phase of infection and it is considered highly specific and able to generate immunological memory ${ }^{94,110}$.

However recent studies demonstrated that also innate immune cells can show adaptive characteristic and this process has been termed "trained immunity" ${ }^{50}$. 'Training' mice with different 
microbial stimuli led to protection against subsequent lethal infection in a non-specific manner $51,70,71$. Since protection conferred by MV130 against both VACV and Influenza A respiratory infections appeared very early, was due to non-specific response against antigenically unrelated pathogens and was maintained along the time, the possible role of MV130 as a stimulus inducing trained immunity was investigated. Following the strategy that is considered the gold-standard of trained immunity ${ }^{51}$ treatment with MV130 resulted in reduced mortality following $C$. albicans infection, highlighting the ability of MV130 to induce heterologous and systemic protection. To rule out the role of adaptive immune system, trained immunity induction was analyzed in Rag1 -/- mice that lack mature B and T lymphocytes and the protective role of MV130 was maintained. In accordance with the previous literature ${ }^{54,51}$ the obtained results further prove that MV130 can be considered a stimulus mediating the induction of trained immunity.

Recent studies affirm that the induction of innate immune memory is not exclusively confined to immune cells but can also occur in stromal and epithelial cells. Epithelial stem cells (EpSCs) are able to acquire a prolonged memory to acute inflammation subsequently enhancing barrier restoration as response to tissue damage. This functional adaptation depends on maintained chromosomal accessibility at key stress response genes that are activated by the primary challenge. Upon a secondary stimulation, genes regulated by these domains are faster transcribed ${ }^{111}$. Local tissue stem cells have been described in airways of the lung. They are considered dispensable for normal airway homeostasis whereas stem cell activation and robust clonal cellular expansion are described to occur during repair from severe lung injury ${ }^{112-114}$. The hypothesis that EpSCs upon a first challenge with MV130, acquire memory favoring a faster tissue repair in response to the viral mediated tissue damage, cannot be discarded. There are also evidences indicating that fibroblasts stimulated with IFN $\beta$ acquire transcriptional memory that led to improved antiviral protection ${ }^{115}$. Alveolar type II epithelial cells synthesize the surfactant protein D (SP-D) that is one of the four proteins belonging to the lipoprotein complex known as pulmonary surfactant. It has been demonstrated that SP-D participate in the host defense functions of surfactant binding to several pathogens and in many cases enhancing their phagocytosis by innate immune cells. For example, SP-D binds to Gram-negative bacteria such as Pseudomonas aeruginosa, Klebsiella pneumoniae, rough strains of Escherichia coli and also other pathogens including Influenza virus, respiratory syncytial virus, and Pneumocystis carinii ${ }^{116}$. In this regard further experimental approaches are necessary to evaluate whether alveolar type II epithelial cells upon MV130 chal- 
lenge undergo long-lasting changes providing enhanced response to local viral infection. Elisa analysis of SP-D levels in the lung surfactant from MV130-treated and control mice, at different time points, could be useful to explain the differences in the lung viral load that appear very early after VACV i.n. infection.

The long-term effects of trained immunity rely on alterations of the hematopoietic system ${ }^{89,92}$. According to that we showed that BMDM coming from mice pretreated with MV130 produced higher levels of TNF $\alpha$ than control ones, in response to LPS. However further studies, including transcriptional approaches, are required to reveal whether the long-term impact of MV130 mediated trained immunity is due to the reprogramming of hematopoietic stem cells. In adult people the beneficial effects associated with MV130 treatment on RRTI were maintained at least for 6 months ${ }^{43}$. However mature cells have a relatively short lifespan in circulation. For that reprogramming of myeloid compartment could explain in part the long term protective effects mediated by MV130 in humans.

Trained cells undergo metabolic changes that result in a shift toward an increase in glycolysis that is dependent on the activation of mTOR through a dectin-1/Akt/Hif1 $\alpha$ pathway. The drug metformin, used for the treatment of type 2 diabetes ${ }^{117}$, acts through AMPK activation and subsequently mTOR inhibition ${ }^{118}$. In this line, the protective effect of MV130 against Influenza A virus was lost when animals were treated with metformin. The precise mechanism of action of metformin relies on the blocking of the complex I of the electron transport chain. This result in a subsequent inhibition of OXPHOS and adenosine triphosphate (ATP) production ${ }^{119,120}$, therefore leading to AMPK activation in numerous cell types ${ }^{121}$. For that, metformin is not directly inhibiting mTOR and this could result in 'side-effects', that are not related to the mTOR pathways. Further studies using other inhibitors, such as rapamycin, or genetic mouse models depleting mTOR, are needed to confirm that the obtained result is exclusively due to mTOR inhibition. Moreover, metformin can also have impact on the adaptive immunity. According to that this drug can reduce oxygen consumption, activation, and IFN- $\gamma$ production in $C D 4^{+} T$ cells of lupus mice ${ }^{122}$ and also type 1 IFN Response in Human $\mathrm{CD}^{+}{ }^{+}$T Cells ${ }^{123}$. Due to the broad range of effects that metformin has in cells, the involvement of additional mechanisms, responsible for the loss of MV130 mediated protection upon treatment with this drug, cannot be ruled out. Interestingly it has been demonstrated that mice bearing floxed mTOR with a CD11c-Cre deleter strain, in which mTOR has been depleted in CD11 $\mathrm{c}^{+}$cells, presented reduced number of $C D 103^{+} \mathrm{DC}$ and alveolar 
macrophages in the lungs ${ }^{124}$. In line with this, MV130, through the activation of the mTOR pathway, could regulate the development of $\mathrm{CD}_{103^{+}} \mathrm{DC}$ that showed a stable increased after both one day and one week after the last i.n. dosis of MV130. In contrast metformin treatment could impede this effect, thus leading to reduced protection. However further investigations are needed to validate this hypothesis.

\section{MV130 in humans: a trained-immunity based vaccine}

In vitro induction of trained immunity has been previously described for different cell types including human monocytes ${ }^{71}$ and human PBMCs ${ }^{76}$. Following a well-defined model of trained immunity in vitro, we demonstrated that human monocytes upon MV130 challenge acquire immune memory. This result, together with the heterologous non-specific protection achieved by MV130 in our in vivo experiments suggests that the beneficial effects of MV130 in patients who suffer from RRTI could rely on the induction of trained immunity. According to that a wide collection of epidemiological data show that live vaccines such as BCG, measles and oral polio vaccine ${ }^{125-127}$ apart from conferring protection against target diseases are also associated with beneficial, non-specific protective effects against infections. Furthermore previous studies described that the protection conferred by BCG vaccination against microbes in models of controlled human infection, such as yellow fever was associated with an enhanced pro-inflammatory state of monocytes ${ }^{79}$. Taken together these evidences lead to a new generation of vaccines defined as trained immunity-based vaccine (TIbV), that can combine induction of classical adaptive immune memory and trained immunity to confer a broad protection ${ }^{128}$. Moreover in a vaccination context we cannot discard the hypothesis that training of innate immune cells may on turn enhance the adaptive responses leading to the induction of heterologous immunity, as it has been described for BCG 53,129,130. According to that human DCs activated with MV130 vaccine are able to induce Th1 and Th17 responses ${ }^{44}$. Based on the wide amount of immune responses promoted by TIbV, they could play an important role in those settings in which conventional vaccines are not available or against pathogens with high mutation rates, such as Influenza virus ${ }^{131}$ or in conditions associated with immune paralysis to restore immune responsiveness ${ }^{88}$. In line with this, mucosal/epithelial damage caused by some respiratory viruses, such as Influenza A, promotes 
increased bacterial colonization of the upper and lower respiratory tract and dysregulation of immune responses which all lead to increased susceptibility to secondary bacterial infections. This phenomenon is called pathogenesis of super-infection ${ }^{132}$. Moreover microbial communities which inhabit our bodies are responsible for the balance between health and susceptibility to diseases, including infections. For that, disruptions in the normal microbial communities by an acute viral infection, lead to a state of dysbiosis, which on turn might contribute to the development of secondary infections ${ }^{133}$. Also in these cases TIbV, due to their immunomodulatory abilities, could be also used to restore the correct functionality of immune responses.

Although trained immunity is associated with better protection against infection, there are some situations in which an exacerbated immune response can have harmful effects driving to disease progression ${ }^{134}$. In this regard trained immunity has been proposed as a mechanism linking infection and development of atherosclerosis ${ }^{135}$. In addition to microbial products also endogenous danger signals can trigger innate immune memory ${ }^{67}$. According to that oxLDL particles are able to induce trained immunity in human monocytes ${ }^{57,62}$ and also studies in patients with gout have shown the ability of uric acid to reprogram hPBMCs that display enhanced proinflammatory cytokine production ${ }^{66,136}$. Another clinical scenario in which endogenous stimuli could trigger trained immunity is represented by organ transplantation, as donor allografts in a murine model of heart transplantation, overexpress vimentin and HMGB1, inducing local training of graft-infiltrating monocyte-derived cells ${ }^{137}$. Moreover monocytes and macrophages coming from patients with a wide variety of both autoimmune and autoinflammatory disorders show a constitutive and damaging trained immunity-like phenotype in terms of cytokine production, metabolic changes and/or epigenetic rewiring. These common features have been found in patients suffering from familial hypercholesterolemia ${ }^{138}$, atherosclerosis ${ }^{62}$ or systemic lupus erythematosus ${ }^{139}$. Moreover, in the context of microglial priming, trained immunity has been postulated to contribute to brain aging ${ }^{140}$ neuropsychiatric disorders ${ }^{141}$ and exacerbated pathology in Alzheimer's disease (AD) and brain stroke ${ }^{142}$. In all these conditions and in presence of chronic inflammatory settings, the use of trained immunity based vaccine needs to be well evaluated.

However in our hands, upon MV130 challenge Tregs in murine lungs were found increased. Also MV130-activated human DCs produce both pro- and anti-inflammatory cytokines and induce not only Th1 and Th17 responses but also IL-10-producing T cells ${ }^{44}$. These results together with our data highlight both sides of the immunomodulatory role of MV130 suggesting that it can trigger 
the induction of innate immune training as well as avoid an exacerbated inflammatory response. However, this dual role of MV130 has to be further explored.

In summary, our data indicate that the polybacterial preparation MV130 is able to protect against viral respiratory infections in mice, inducing trained immunity. Moreover, we show that MV130 can also train human monocytes. In line with this, the beneficial therapeutic effects promoted by MV130 in humans, against RRTI, could be also due to the induction of trained immunity $53,129,130$. Taken together, this study opens new clinical perspectives about the possible role of polybacterial mucosal preparations, to protect against a wide range of different pathogens, thus acting as TIbV ${ }^{128}$ (Figure D2).
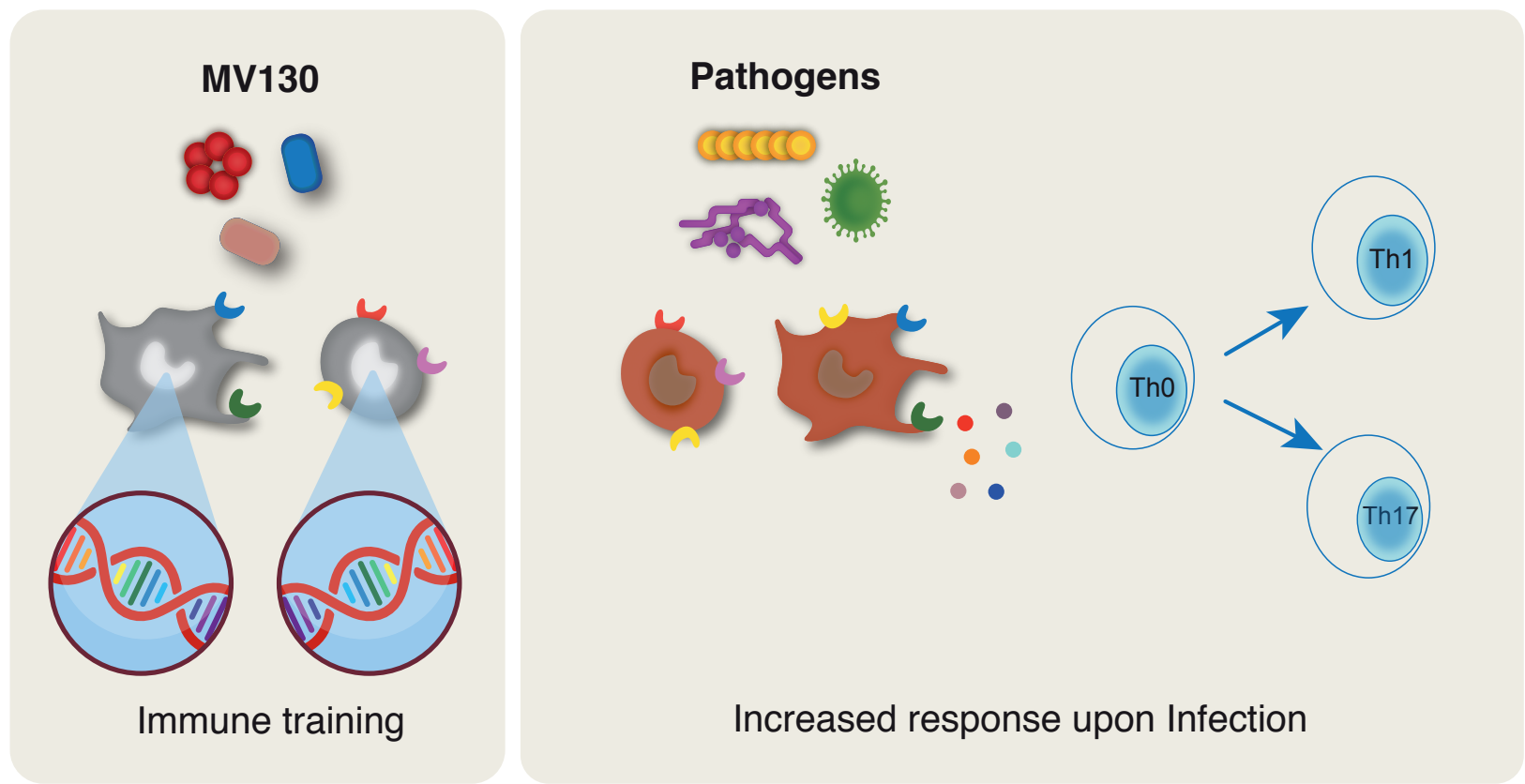

FigureD2. Trained Immunity-based Vaccine TIbV: Suggested working model for MV130 that could act as a TIbV, conferring non-specific protection against different pathogens. MV130 trains innate immune cells that, in presence of a secondary infection, show better activation and enhanced cytokines production. In this way MV130 could also enhance the adaptive responses leading to the induction of heterologous immunity. 
CONCLUSIONS
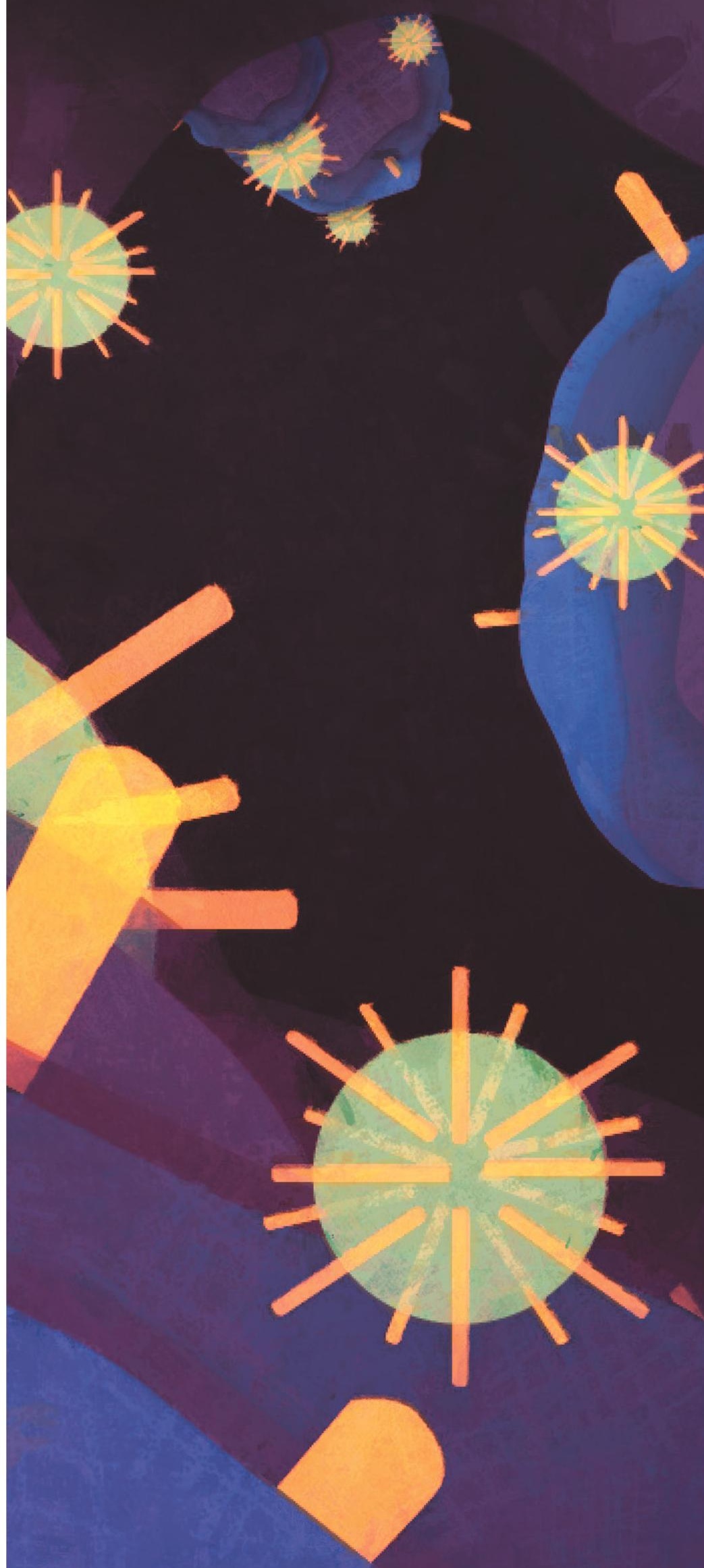

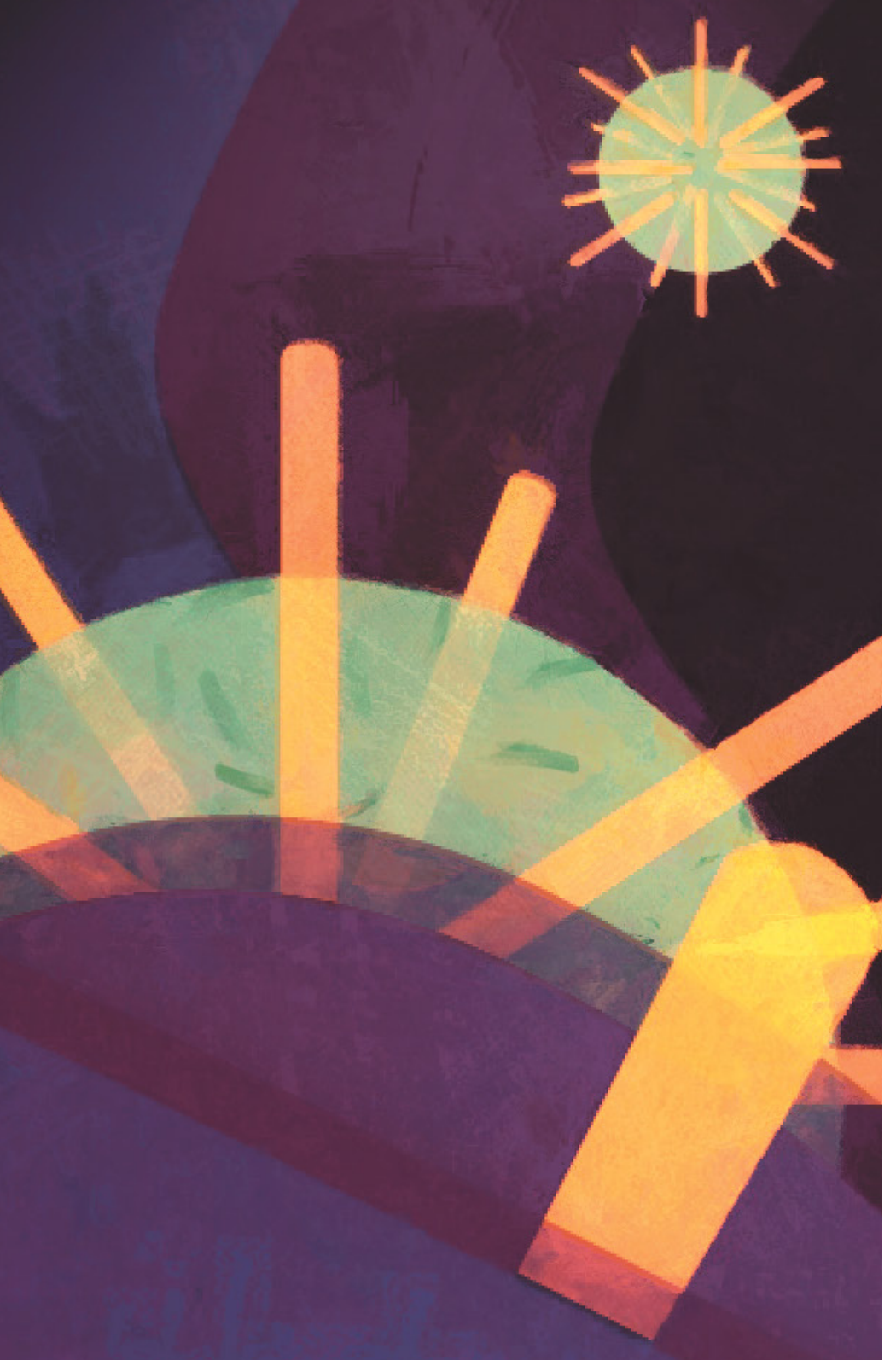


\section{Conclusions}

1. Intranasal administration of the polybacterial mucosal vaccine MV130 in mice, confers cross-protection against viral respiratory infections. This results in reduced lung viral load, less weight loss and better survival.

2. MV130 promotes the infiltration of both myeloid and lymphoid cell subsets in the lung.

3. Intranasal administration of MV130 protects against systemic C. albicans infection.

4. The systemic protection conferred by MV130 against $C$. albicans infection does not rely on the adaptive immune system.

5. MV130 educates bone marrow hematopoietic progenitors generating trained-mature cells.

6. Inhibition of mTOR pathway, involved in trained immunity, results in reduced MV130 mediated protection.

7. MV130 induces trained immunity in human monocytes resulting in increased lactate levels and in enhanced cytokines production associated with epigenetic changes. 

CONCLUSIONES 


\section{Conclusiones}

1. La administración intranasal de la vacuna de mucosa polibacteriana MV130 en ratones confiere protección cruzada contra infecciones respiratorias virales. Esto da como resultado una carga viral pulmonar reducida, menor pérdida de peso y una mejor supervivencia.

2. MV130 promueve la infiltración de poblaciones de células tanto mieloides como linfoides en el pulmón.

3. La administración intranasal de MV130 protege contra la infección sistémica de C. albicans.

4. La protección sistémica conferida por MV130 contra la infección por C. albicans no depende del sistema inmunitario adaptativo.

5. MV130 educa a los progenitores hematopoyéticos de médula ósea generando células maduras entrenadas.

6. La inhibición de la vía mTOR, implicada en el mecanismo de inmunidad entrenada, da como resultado menor protección mediada por MV130.

7. MV130 induce inmunidad entrenada en monocitos humanos dando como resultado niveles aumentados de lactato y una producción mejorada de citocinas asociada con cambios epigenéticos. 

BIBLIOGRAPHY

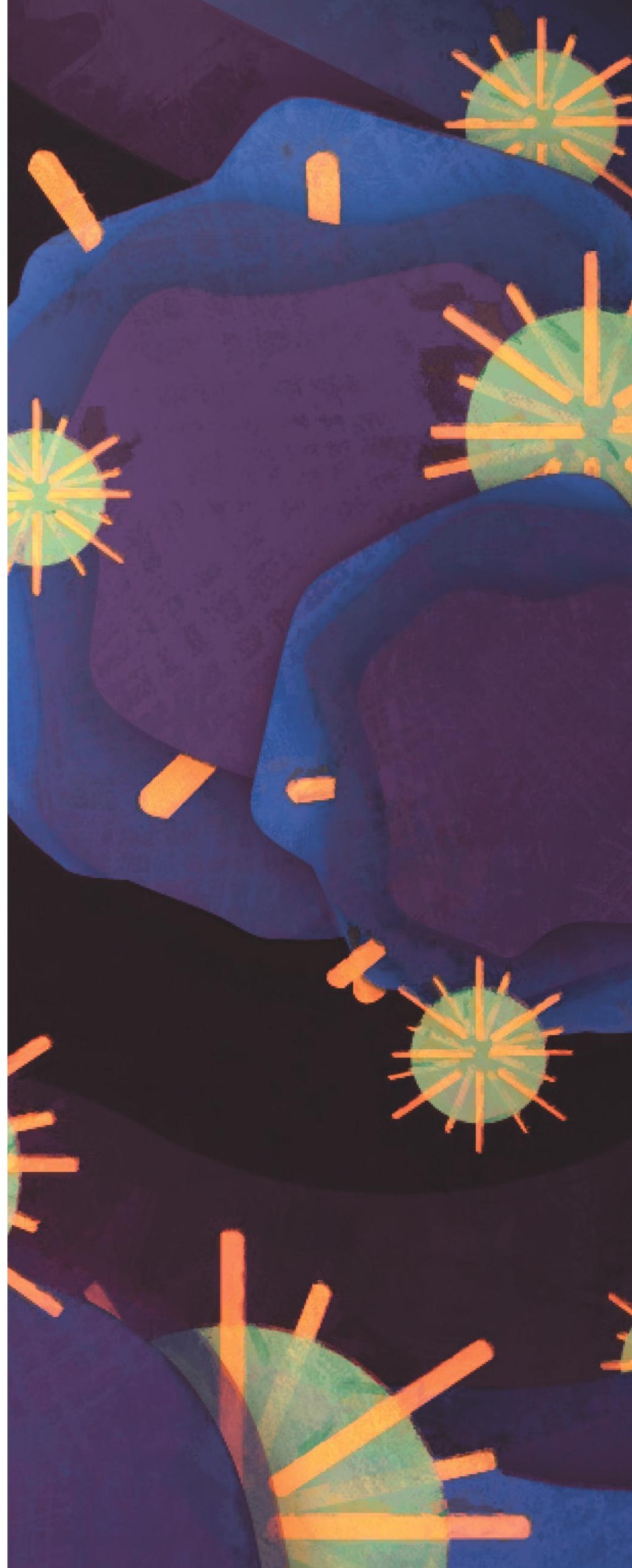



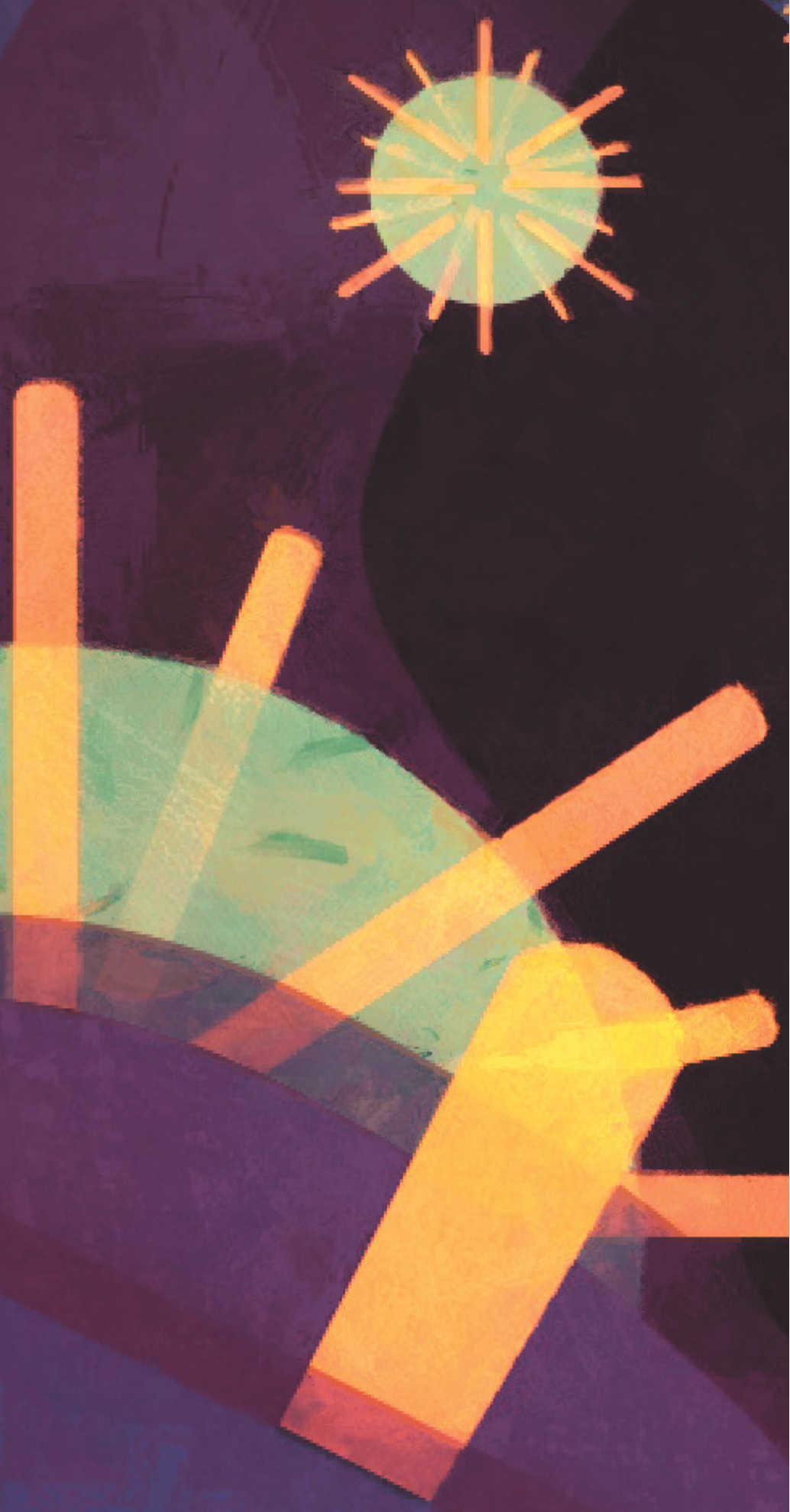


\section{BIBLIOGRAPHY}

1. Online Etymology Dictionary | Origin, history and meaning of English words. Available at: https://www.etymonline.com/. (Accessed: 16th October 2019)

2. Retief, F. P. \& Cilliers, L. The epidemic of Athens, $430-426$ BC. S. Afr. Med. J. 88, 50-3 (1998).

3. Janeway, C. A. Approaching the Asymptote? Evolution and Revolution in Immunology. Cold Spring Harb. Symp. Quant. Biol. 54, 1-13 (1989).

4. Iwasaki, A. \& Medzhitov, R. Control of adaptive immunity by the innate immune system. Nat. Immunol. 16, 343-353 (2015).

5. Zinkernagel, R. M. et al. On Immunological Memory. Annu. Rev. Immunol. 14, 333-367 (1996).

6. Limon, J. J., Skalski, J. H. \& Underhill, D. M. Commensal Fungi in Health and Disease. Cell Host Microbe 22, 156-165 (2017).

7. Mirzaei, M. K. \& Maurice, C. F. Ménage à trois in the human gut: interactions between host, bacteria and phages. Nat. Rev. Microbiol. 15, 397-408 (2017).

8. Brestoff, J. R. \& Artis, D. Commensal bacteria at the interface of host metabolism and the immune system. Nat. Immunol. 14, 676-84 (2013).

9. Lozupone, C. A., Stombaugh, J. I., Gordon, J. I., Jansson, J. K. \& Knight, R. Diversity, stability and resilience of the human gut microbiota. Nature 489, 220-30 (2012). 
10. Khosravi, A. et al. Gut Microbiota Promote Hematopoiesis to Control Bacterial Infection. Cell Host Microbe 15, 374-381 (2014).

11. Zhang, J. et al. A phylo-functional core of gut microbiota in healthy young Chinese cohorts across lifestyles, geography and ethnicities. ISME J. 9, 1979-90 (2015).

12. Salem, I., Ramser, A., Isham, N. \& Ghannoum, M. A. The Gut Microbiome as a Major Regulator of the Gut-Skin Axis. Front. Microbiol. 9, 1459 (2018).

13. Levy, M., Kolodziejczyk, A. A., Thaiss, C. A. \& Elinav, E. Dysbiosis and the immune system. Nat. Rev. Immunol. 17, 219-232 (2017).

14. Zechner, E. L. Inflammatory disease caused by intestinal pathobionts. Curr. Opin. Microbiol. 35, 64-69 (2017).

15. Brandtzaeg, P. Mucosal immunity: Induction, dissemination, and effector functions. Scand. J. Immunol. 70, 505-515 (2009).

16. Kiyono, H. \& Azegami, T. The mucosal immune system: From dentistry to vaccine development. Proc. Japan Acad. Ser. B 91, 423-439 (2015).

17. Sato, S. \& Kiyono, H. The mucosal immune system of the respiratory tract. Curr. Opin. Virol. 2, 225-232 (2012).

18. Lamichhane, A., Azegami, T. \& Kiyono, H. The mucosal immune system for vaccine development. Vaccine 32, 6711-6723 (2014).

19. Boyaka, P. N. Inducing Mucosal IgA: A Challenge for Vaccine Adjuvants and Delivery Systems. J. Immunol. 199, 9-16 (2017).

20. Ogra, P. L., Faden, H. \& Welliver, R. C. Vaccination strategies for mucosal immune responses. Clin. Microbiol. Rev. 14, 430-45 (2001).

21. Pedersen, G. K. et al. Evaluation of the Sublingual Route for Administration of Influenza H5N1 Virosomes in Combination with the Bacterial Second Messenger c-di-GMP. PLoS One 6, e26973 (2011).

22. WHO | Practical approach to lung health. WHO (2015).

23. Zumla, A. Current trends and newer concepts on diagnosis, management and preven- 
tion of respiratory tract infections. Curr. Opin. Pulm. Med. 19, 189-91 (2013).

24. Braido, F., Tarantini, F., Ghiglione, V., Melioli, G. \& Canonica, G. W. Bacterial lysate in the prevention of acute exacerbation of COPD and in respiratory recurrent infections. Int. J. COPD 2, 335-345 (2007).

25. Vandini, S., Biagi, C., Fischer, M. \& Lanari, M. Impact of rhinovirus infections in children. Viruses 11, 1-13 (2019).

26. Toivonen, L. et al. Burden of Recurrent Respiratory Tract Infections in Children. Pediatr. Infect. Dis. J. 35, e362-e369 (2016).

27. Shinya, K. et al. Influenza virus receptors in the human airway. Nature 440, 435-436 (2006).

28. Holt, P. G., Strickland, D. H., Wikström, M. E. \& Jahnsen, F. L. Regulation of immunological homeostasis in the respiratory tract. Nat. Rev. Immunol. 8, 142-152 (2008).

29. Kirby, A. C., Coles, M. C. \& Kaye, P. M. Alveolar macrophages transport pathogens to lung draining lymph nodes. J. Immunol. 183, 1983-9 (2009).

30. Braciale, T. J., Sun, J. \& Kim, T. S. Regulating the adaptive immune response to respiratory virus infection. Nat. Rev. Immunol. 12, 295-305 (2012).

31. Esposito, S. et al. Nonspecific immunomodulators for recurrent respiratory tract infections, wheezing and asthma in children: a systematic review of mechanistic and clinical evidence. Curr. Opin. Allergy Clin. Immunol. 18, 198-209 (2018).

32. Strachan, D. P. Hay fever, hygiene, and household size. BMJ 299, 1259-60 (1989).

33. Illi, S. et al. Early childhood infectious diseases and the development of asthma up to school age: a birth cohort study. BMJ 322, 390-5 (2001).

34. Feldman, A. S., He, Y., Moore, M. L., Hershenson, M. B. \& Hartert, T. V. Toward primaryprevention of asthma. Reviewing the evidence for early-life respiratory viral infections as modifiable risk factors to prevent childhood asthma. Am. J. Respir. Crit. Care Med. 191, 34-44 (2015).

35. Rook, G. A. W. Hygiene Hypothesis and Autoimmune Diseases. Clin. Rev. Allergy Immunol. 42, 5-15 (2012). 
36. Hanski, I. et al. Environmental biodiversity, human microbiota, and allergy are interrelated. Proc. Natl. Acad. Sci. U. S. A. 109, 8334-9 (2012).

37. Dumas, A., Bernard, L., Poquet, Y., Lugo-Villarino, G. \& Neyrolles, O. The role of the lung microbiota and the gut-lung axis in respiratory infectious diseases. Cell. Microbiol. 20, 1-9 (2018).

38. Trompette, A. et al. Dietary Fiber Confers Protection against Flu by Shaping Ly6c- Patrolling Monocyte Hematopoiesis and CD8+ T Cell Metabolism. Immunity 48, 992-1005. e8 (2018).

39. Rozy, A. \& Chorostowska-Wynimko, J. Bacterial immunostimulants - Mechanism of action and clinical application in respiratory diseases. Pneumonol. Alergol. Pol. 76, 353359 (2008).

40. Schaad, U. B., Mütterlein, R., Goffin, H. \& BV-Child Study Group. Immunostimulation with OM-85 in Children with Recurrent Infections of the Upper Respiratory Tract. Chest 122, 2042-2049 (2002).

41. Ruah, S. B., Ruah, C., van Aubel, A., Abel, S. \& Elsasser, U. Efficacy of a polyvalent bacterial lysate in children with recurrent respiratory tract infections. Adv. Ther. 18, 151-62

42. Razi, C. H. et al. The immunostimulant OM-85 BV prevents wheezing attacks in preschool children. J. Allergy Clin. Immunol. 126, 763-769 (2010).

43. Alecsandru, D. et al. Sublingual therapeutic immunization with a polyvalent bacterial preparation in patients with recurrent respiratory infections: immunomodulatory effect on antigen-specific memory CD4+ T cells and impact on clinical outcome. Clin. Exp. Immunol. 164, 100-7 (2011).

44. Cirauqui, C. et al. Human dendritic cells activated with MV130 induce Th1, Th17 and IL-10 responses via RIPK2 and MyD88 signalling pathways. Eur. J. Immunol. 48, 180-193 (2018).

45. Dangl, J. L. \& Jones, J. D. G. Plant pathogens and integrated defence responses to infection. Nature 411, 826-833 (2001).

46. Sticher, L., Mauch-Mani, B. \& Métraux, and J. Systemic Acquired Resistance. Annu. Rev. Phytopathol. 35, 235-270 (1997). 
47. Durrant, W. E. \& Dong, X. Systemic Acquired Resistance. Annu. Rev. Phytopathol. 42, 185-209 (2004).

48. Kurtz, J. Specific memory within innate immune systems. Trends Immunol. 26, 186-192 (2005).

49. Moret, Y. \& Siva-Jothy, M. T. Adaptive innate immunity? Responsive-mode prophylaxis in the mealworm beetle, Tenebrio molitor. Proceedings. Biol. Sci. 270, 2475-80 (2003).

50. Netea, M. G., Quintin, J. \& van der Meer, J. W. M. Trained Immunity: A Memory for Innate Host Defense. Cell Host Microbe 9, 355-361 (2011).

51. Quintin, J. et al. Candida albicans infection affords protection against reinfection via functional reprogramming of monocytes. Cell Host Microbe 12, 223-32 (2012).

52. Netea, M. G. \& Joosten, L. A. B. Master and commander: Epigenetic regulation of macrophages. Cell Res. 26, 145-146 (2016).

53. Kleinnijenhuis, J. et al. Long-lasting effects of BCG vaccination on both heterologous Th1/Th17 responses and innate trained immunity. J. Innate Immun. 6, 152-8 (2014).

54. Kleinnijenhuis, J. et al. Bacille Calmette-Guérin induces NOD2-dependent nonspecific protection from reinfection via epigenetic reprogramming of monocytes. Proc. Natl. Acad. Sci. U. S. A. 109, 17537-17542 (2012).

55. Rusek, P., Wala, M., Druszczyńska, M. \& Fol, M. Infectious Agents as Stimuli of Trained Innate Immunity. Int. J. Mol. Sci. 19, (2018).

56. Bekkering, S. et al. In Vitro Experimental Model of Trained Innate Immunity in Human Primary Monocytes. Clin. Vaccine Immunol. 23, 926-933 (2016).

57. Kleinnijenhuis, J. et al. BCG-induced trained immunity in NK cells: Role for non-specific protection to infection. Clin. Immunol. 155, 213-219 (2014).

58. Holmes, T. D. \& Bryceson, Y. T. Natural killer cell memory in context. Semin. Immunol. 28, 368-376 (2016).

59. Netea, M. G. \& van der Meer, J. W. M. Trained Immunity: An Ancient Way of Remembering. Cell Host Microbe 21, 297-300 (2017). 
60. Hole, C. R. et al. Induction of memory-like dendritic cell responses in vivo. Nat. Commun. 10, 1-13 (2019).

61. Ifrim, D. C. et al. Trained Immunity or Tolerance: Opposing Functional Programs Induced in Human Monocytes after Engagement of Various Pattern Recognition Receptors. Clin. Vaccine Immunol. 21, 534-545 (2014).

62. Bekkering, S. et al. Oxidized Low-Density Lipoprotein Induces Long-Term Proinflammatory Cytokine Production and Foam Cell Formation via Epigenetic Reprogramming of Monocytes. Arterioscler. Thromb. Vasc. Biol. 34, 1731-1738 (2014).

63. Bekkering, S. et al. Metabolic Induction of Trained Immunity through the Mevalonate Pathway. Cell 172, 135-146.e9 (2018).

64. Arts, R. J. W. et al. Glutaminolysis and Fumarate Accumulation Integrate Immunometabolic and Epigenetic Programs in Trained Immunity. Cell Metab. 24, 807-819 (2016).

65. van Splunter, M. et al. Induction of Trained Innate Immunity in Human Monocytes by Bovine Milk and Milk-Derived Immunoglobulin G. Nutrients 10, 1378 (2018).

66. Crișan, T. O. et al. Soluble uric acid primes TLR-induced proinflammatory cytokine production by human primary cells via inhibition of IL-1Ra. Ann. Rheum. Dis. 75, 755-762 (2016).

67. Crișan, T. O., Netea, M. G. \& Joosten, L. A. B. Innate immune memory: Implications for host responses to damage-associated molecular patterns. Eur. J. Immunol. 46, 817-828 (2016).

68. Brubaker, S. W., Bonham, K. S., Zanoni, I. \& Kagan, J. C. Innate Immune Pattern Recognition: A Cell Biological Perspective. Annu. Rev. Immunol. 33, 257-290 (2015).

69. Walachowski, S., Tabouret, G., Fabre, M. \& Foucras, G. Molecular analysis of a shortterm model of $\beta$-glucans-trained immunity highlights the accessory contribution of GMCSF in priming mouse macrophages response. Front. Immunol. 8, 1-15 (2017).

70. Saz-Leal, P. et al. Targeting SHIP-1 in Myeloid Cells Enhances Trained Immunity and Boosts Response to Infection. Cell Rep. 25, 1118-1126 (2018).

71. Cheng, S.-C. et al. mTOR- and HIF-1 $\alpha$-mediated aerobic glycolysis as metabolic basis for trained immunity. Science 345, 1250684 (2014). 
72. Netea, M. G., Joosten, L. A. B., van der Meer, J. W. M., Kullberg, B.-J. \& van de Veerdonk, F. L. Immune defence against Candida fungal infections. Nat. Rev. Immunol. 15, 630-642 (2015).

73. Netea, M. G., Latz, E., Mills, K. H. G. \& O’Neill, L. A. J. Innate immune memory: a paradigm shift in understanding host defense. Nat. Immunol. 16, 675-679 (2015).

74. Ifrim, D. C. et al. Defective trained immunity in patients with STAT-1-dependent chronic mucocutaneaous candidiasis. Clin. Exp. Immunol. 181, 434-440 (2015).

75. Ifrim, D. C. et al. Candida albicans Primes TLR Cytokine Responses through a Dectin-1/ Raf-1-Mediated Pathway. J. Immunol. 190, 4129-4135 (2013).

76. Schrum, J. E. et al. Cutting Edge: Plasmodium falciparum Induces Trained Innate Immunity. J. Immunol. 200, 1243-1248 (2018).

77. Garcia-Valtanen, P., Guzman-Genuino, R. M., Williams, D. L., Hayball, J. D. \& Diener, K. R. Evaluation of trained immunity by $\beta-1,3$ (d)-glucan on murine monocytes in vitro and duration of response in vivo. Immunol. Cell Biol. 95, 601-610 (2017).

78. Arts, R. J. W. et al. BCG Vaccination Protects against Experimental Viral Infection in Humans through the Induction of Cytokines Associated with Trained Immunity. Cell Host Microbe 23, 89-100.e5 (2018).

79. Bree, L. C. J. de et al. Bacillus Calmette-Guérin-Induced Trained Immunity Is Not Protective for Experimental Influenza A/Anhui/1/2013 (H7N9) Infection in Mice. Front. Immunol. 9, (2018).

80. Arts, R. J. W., Joosten, L. A. B. \& Netea, M. G. Immunometabolic circuits in trained immunity. Semin. Immunol. 28, 425-430 (2016).

81. Saeed, S. et al. Epigenetic programming of monocyte-to-macrophage differentiation and trained innate immunity. Science (80-. ). 345, 1251086-1251086 (2014).

82. Christ, A. et al. Western Diet Triggers NLRP3-Dependent Innate Immune Reprogramming. Cell 172, 162-175.e14 (2018).

83. Domínguez-Andrés, J. et al. The Itaconate Pathway Is a Central Regulatory Node Linking Innate Immune Tolerance and Trained Immunity. Cell Metab. 29, 211-220.e5 (2019). 
84. Christ, A., Bekkering, S., Latz, E. \& Riksen, N. P. Long-term activation of the innate immune system in atherosclerosis. Semin. Immunol. 28, 384-393 (2016).

85. Biswas, S. K. \& Lopez-Collazo, E. Endotoxin tolerance: new mechanisms, molecules and clinical significance. Trends Immunol. 30, 475-487 (2009).

86. Hoeksema, M. A. \& de Winther, M. P. J. Epigenetic Regulation of Monocyte and Macrophage Function. Antioxid. Redox Signal. 25, 758-774 (2016).

87. Foster, S. L., Hargreaves, D. C. \& Medzhitov, R. Gene-specific control of inflammation by TLR-induced chromatin modifications. Nature 447, 972-978 (2007).

88. Novakovic, B. et al. $\beta$-Glucan Reverses the Epigenetic State of LPS-Induced Immunological Tolerance. Cell 167, 1354-1368.e14 (2016).

89. Mitroulis, I. et al. Modulation of Myelopoiesis Progenitors Is an Integral Component of Trained Immunity. Cell 172, 147-161.e12 (2018).

90. Kaufmann, E. et al. BCG Educates Hematopoietic Stem Cells to Generate Protective Innate Immunity against Tuberculosis. Cell 172, 176-190.e19 (2018).

91. Meissner, H. C. Viral Bronchiolitis in Children. N. Engl. J. Med. 374, 62-72 (2016).

92. Murata, Y., Walsh, E. E. \& Falsey, A. R. Pulmonary Complications of Interpandemic Influenza A in Hospitalized Adults. J. Infect. Dis. 195, 1029-1037 (2007).

93. Nair, H. et al. Global burden of respiratory infections due to seasonal influenza in young children: a systematic review and meta-analysis. Lancet 378, 1917-1930 (2011).

94. Medzhitov, R. \& Janeway, C. Innate Immunity. N. Engl. J. Med. 343, 338-344 (2000).

95. Arts, R. J. W. et al. Immunometabolic Pathways in BCG-Induced Trained Immunity. Cell Rep. 17, 2562-2571 (2016).

96. Thirion-Delalande, C. et al. Comparative analysis of the oral mucosae from rodents and non-rodents: Application to the nonclinical evaluation of sublingual immunotherapy products. PLoS One 12, e0183398 (2017).

97. Masieri, S. et al. A role for Waldeyer's ring in immunological response to allergens. Curr. Med. Res. Opin. 30, 203-205 (2014). 
98. Velin, D., Fotopoulos, G., Luthi, F. \& Kraehenbuhl, J. P. The nasal-associated lymphoid tissue of adult mice acts as an entry site for the mouse mammary tumor retrovirus. $J$. Exp. Med. 185, 1871-6 (1997).

99. Bessler, W. G., vor dem Esche, U. \& Masihi, N. The bacterial extract OM-85 BV protects mice against Influenza and Salmonella infection. Int. Immunopharmacol. 10, 1086-1090 (2010).

100. Dang, A. T. \& Marsland, B. J. Microbes, metabolites, and the gut-lung axis. Mucosal Immunol. 12, 843-850 (2019).

101. Marsland, B. J., Trompette, A. \& Gollwitzer, E. S. The Gut-Lung Axis in Respiratory Disease. Ann. Am. Thorac. Soc. 12 Suppl 2, S150-6 (2015).

102. Hervouet, C. et al. Langerhans Cells Prime IL-17-Producing T Cells and Dampen Genital Cytotoxic Responses following Mucosal Immunization. J. Immunol. 184, 4842-4851 (2010).

103. Ruane, D. et al. Lung dendritic cells induce migration of protective T cells to the gastrointestinal tract. J. Exp. Med. 210, 1871-1888 (2013).

104. Roberts, J. N. et al. Genital transmission of HPV in a mouse model is potentiated by nonoxynol-9 and inhibited by carrageenan. Nat. Med. 13, 857-861 (2007).

105. Parola, C. et al. Selective activation of human dendritic cells by OM-85 through a NF-kB and MAPK dependent pathway. PLoS One 8, e82867 (2013).

106. Khare, A. et al. Cutting edge: inhaled antigen upregulates retinaldehyde dehydrogenase in lung CD103+ but not plasmacytoid dendritic cells to induce Foxp3 de novo in CD4+ T cells and promote airway tolerance. J. Immunol. 191, 25-9 (2013).

107. Duan, W. \& Croft, M. Control of regulatory T cells and airway tolerance by lung macrophages and dendritic cells. Ann. Am. Thorac. Soc. 11 Suppl 5, S306-13 (2014).

108. Desai, P., Tahiliani, V., Abboud, G., Stanfield, J. \& Salek-Ardakani, S. Batf3-Dependent Dendritic Cells Promote Optimal CD8 T Cell Responses against Respiratory Poxvirus Infection. J. Virol. 92, (2018).

109. Helft, J. et al. Cross-presenting CD103+ dendritic cells are protected from influenza virus infection. J. Clin. Invest. 122, 4037-47 (2012). 
110. Mogensen, T. H. Pathogen recognition and inflammatory signaling in innate immune defenses. Clin. Microbiol. Rev. 22, 240-73, Table of Contents (2009).

111. Naik, S. et al. Inflammatory memory sensitizes skin epithelial stem cells to tissue damage. Nature 550, 475-480 (2017).

112. Giangreco, A. et al. Stem cells are dispensable for lung homeostasis but restore airways after injury. Proc. Natl. Acad. Sci. 106, 9286-9291 (2009).

113. Hogan, B. L. M. et al. Repair and Regeneration of the Respiratory System: Complexity, Plasticity, and Mechanisms of Lung Stem Cell Function. Cell Stem Cell 15, 123-138 (2014).

114. Donne, M. L., Lechner, A. J. \& Rock, J. R. Evidence for lung epithelial stem cell niches. BMC Dev. Biol. 15, (2015).

115. Kamada, R. et al. Interferon stimulation creates chromatin marks and establishes transcriptional memory. Proc. Natl. Acad. Sci. U. S. A. 115, E9162-E9171 (2018).

116. Alcorn, J. F. \& Wright, J. R. Degradation of pulmonary surfactant protein D by Pseudomonas aeruginosa elastase abrogates innate immune function. J. Biol. Chem. 279, 30871-9 (2004).

117. Bosi, E. Metformin - the gold standard in type 2 diabetes: what does the evidence tell us? Diabetes, Obes. Metab. 11, 3-8 (2009).

118. Gwinn, D. M. et al. AMPK Phosphorylation of Raptor Mediates a Metabolic Checkpoint. Mol. Cell 30, 214-226 (2008).

119. Mehta, M. M. \& Chandel, N. S. Targeting metabolism for lupus therapy. Sci. Transl. Med. 7, 274fs5 (2015).

120. Wheaton, W. W. et al. Metformin inhibits mitochondrial complex I of cancer cells to reduce tumorigenesis. Elife 3, e02242 (2014).

121. He, L. \& Wondisford, F. E. Metformin Action: Concentrations Matter. Cell Metab. 21, 159-162 (2015).

122. Yin, Y. et al. Normalization of CD4+ T cell metabolism reverses lupus. Sci. Transl. Med. 7, 274 ra18 (2015). 
123. Titov, A. A., Baker, H. V, Brusko, T. M., Sobel, E. S. \& Morel, L. Metformin Inhibits the Type 1 IFN Response in Human CD4+ T Cells. J. Immunol. 203, 338-348 (2019).

124. Sinclair, C. et al. mTOR regulates metabolic adaptation of APCs in the lung and controls the outcome of allergic inflammation. Science (80-. ). 357, 1014-1021 (2017).

125. Biering-Sørensen, S. et al. Early BCG-Denmark and Neonatal Mortality Among Infants Weighing \&lt;2500 g: A Randomized Controlled Trial. Clin. Infect. Dis. 65, 1183-1190 (2017).

126. Lund, N. et al. The Effect of Oral Polio Vaccine at Birth on Infant Mortality: A Randomized Trial. Clin. Infect. Dis. 61, 1504-1511 (2015).

127. Aaby, P. et al. Non-specific beneficial effect of measles immunisation: analysis of mortality studies from developing countries. BMJ 311, 481-5 (1995).

128. Sánchez-Ramón, S. et al. Trained Immunity-Based Vaccines: A New Paradigm for the Development of Broad-Spectrum Anti-infectious Formulations. Front. Immunol. 9, 2936 (2018).

129. Blok, B. A., Arts, R. J. W., van Crevel, R., Benn, C. S. \& Netea, M. G. Trained innate immunity as underlying mechanism for the long-term, nonspecific effects of vaccines. $J$. Leukoc. Biol. 98, 347-356 (2015).

130. de Bree, L. C. J. et al. Non-specific effects of vaccines: Current evidence and potential implications. Semin. Immunol. 39, 35-43 (2018).

131. Kumar, A., Meldgaard, T. S. \& Bertholet, S. Novel Platforms for the Development of a Universal Influenza Vaccine. Front. Immunol. 9, 600 (2018).

132. McCullers, J. A. Preventing and treating secondary bacterial infections with antiviral agents. Antivir. Ther. 16, 123 (2011).

133. Hanada, S., Pirzadeh, M., Carver, K. Y. \& Deng, J. C. Respiratory Viral Infection-Induced Microbiome Alterations and Secondary Bacterial Pneumonia. Front. Immunol. 9, 2640 (2018).

134. Netea, M. G. et al. Trained immunity: A program of innate immune memory in health and disease. Science 352, aaf1098 (2016). 
135. Leentjens, J. et al. Trained Innate Immunity as a Novel Mechanism Linking Infection and the Development of Atherosclerosis. Circ. Res. 122, 664-669 (2018).

136. Crişan, T. O. et al. Uric acid priming in human monocytes is driven by the AKT-PRAS40 autophagy pathway. Proc. Natl. Acad. Sci. U. S. A. 114, 5485-5490 (2017).

137. Braza, M. S. et al. Inhibiting Inflammation with Myeloid Cell-Specific Nanobiologics Promotes Organ Transplant Acceptance. Immunity 49, 819-828.e6 (2018).

138. Bekkering, S. et al. Treatment with Statins Does Not Revert Trained Immunity in Patients with Familial Hypercholesterolemia. Cell Metab. 30, 1-2 (2019).

139. Arts, R. J. W., Joosten, L. A. B. \& Netea, M. G. The Potential Role of Trained Immunity in Autoimmune and Autoinflammatory Disorders. Front. Immunol. 9, 298 (2018).

140. Haley, M. J., Brough, D., Quintin, J. \& Allan, S. M. Microglial Priming as Trained Immunity in the Brain. Neuroscience 405, 47-54 (2019).

141. Salam, A. P., Pariante, C. M. \& Zunszain, P. Innate Immune Memory: Implications for Microglial Function and Neuroprogression. in Modern trends in pharmacopsychiatry 31, 67-78 (2017).

142. Wendeln, A.-C. et al. Innate immune memory in the brain shapes neurological disease hallmarks. Nature 556, 332-338 (2018). 
APPENDIX

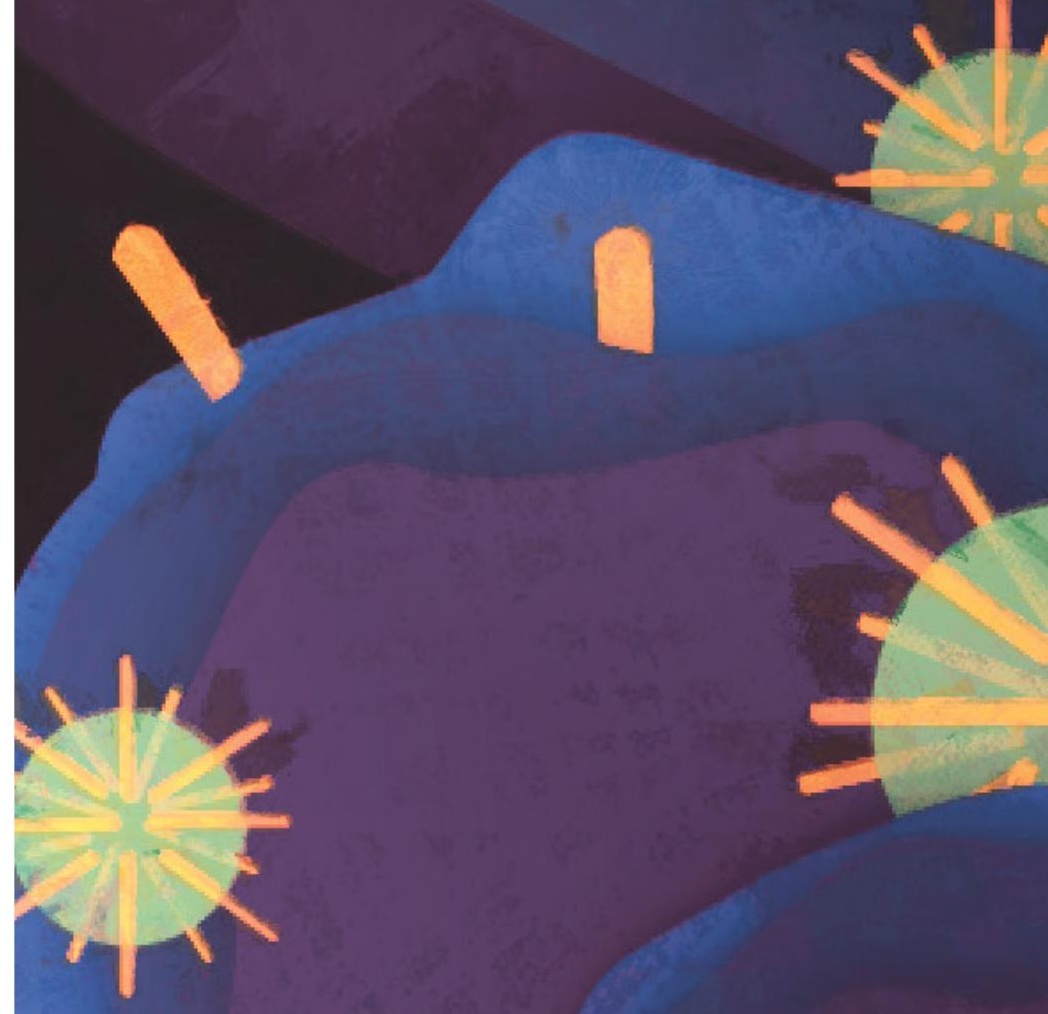




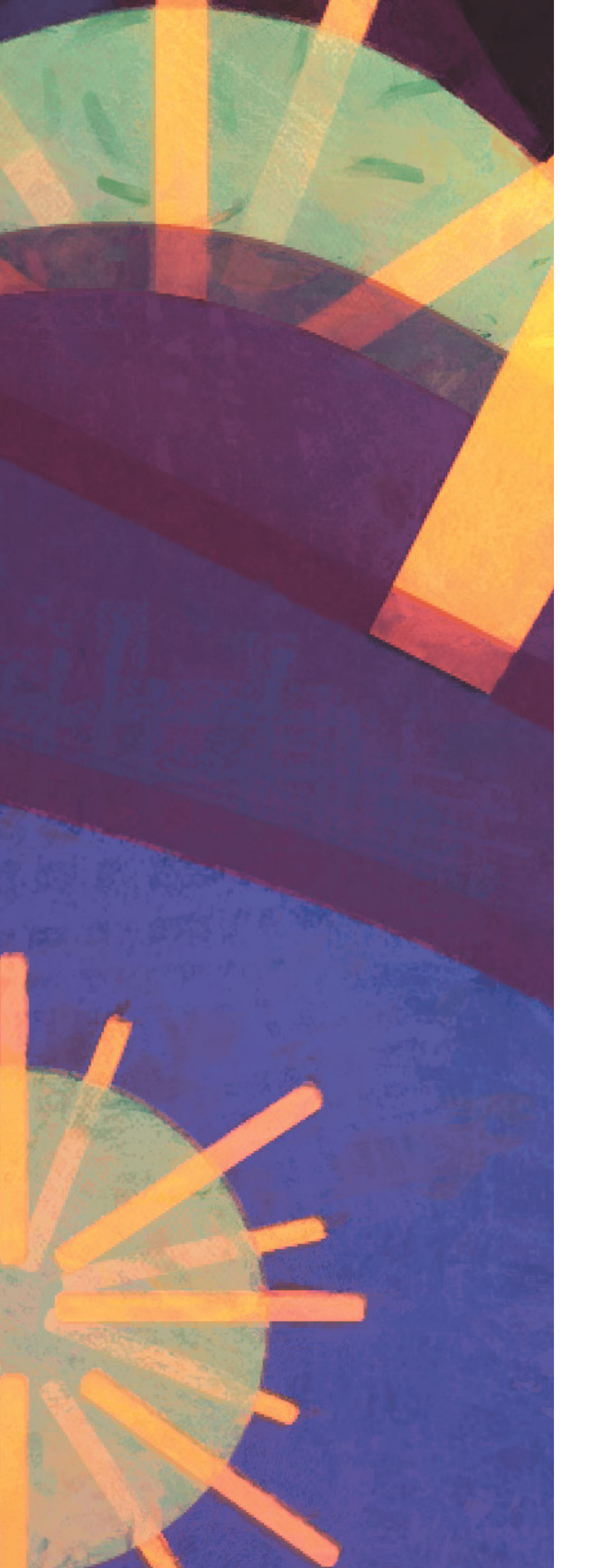




\section{Publication derived from this work:}

\section{Manuscript in preparation}

$-\mathrm{MV130}$ reduces wheezing attacks in children and triggers trained immunity

Nieto, A., Brandi, P.* , Conejero, L., Mazón, A., Nieto, M., Cueto, F.J., Martínez-Cano, M., Calderón, R., Calaforra, S., Selva, B., Uixera, S., Palau, M.J., Saz-Leal, P., Enamorado, M., Amores-Iniesta, J., Fernández-Pérez, C., Casanovas, M., Subiza, J.L. \& Sancho, S.

In preparation.

Co-first authors

\section{Other publications during PhD training}

-DNGR-1 Acts as a cDC1-specific Checkpoint during Flt3L-based Cancer Immunotherapy.

Cueto, F.J., del Fresno, C., Brandi, P., Combes, A., Gómez, M.J., Sánchez-Paulete, A.R., Enamorado, M., Giampazolias, E., Conde-Garrosa, R., Reis e Sousa, C., Melero, I., Krummel, M.F. \& Sancho, D. In preparation. 
-Human dendritic cells activated with MV130 induce Th1, Th17 and IL-10 responses via RIPK2 and MyD88 signalling pathways.

Cirauqui C, Benito-Villalvilla C, Sánchez-Ramón S, Sirvent S, Diez-Rivero CM, Conejero L, Brandi P, Hernández-Cillero L, Ochoa JL, Pérez-Villamil B, Sancho D, Subiza JL, Palomares O.

Eur J Immunol. 2018 Jan. doi: 10.1002/eji.201747024.

-Lung CD103+ dendritic cells restrain allergic airway inflammation through IL-12 production.

Conejero L, Khouili SC, Martínez-Cano S, Izquierdo HM, Brandi P, Sancho D.

JCI Insight. 2017 May 18. doi: 10.1172/jci.insight.90420.

-Von Hippel-Lindau Protein Is Required for Optimal Alveolar Macrophage Terminal Differentiation,Self-Renewal, and Function.

Izquierdo HM, Brandi P, Gómez MJ, Conde-Garrosa R, Priego E, Enamorado M, Martínez-Cano S, Sánchez I, Conejero L, Jimenez-Carretero D, Martín-Puig S, Guilliams M, Sancho D.

Cell Rep. 2018 Aug 14. doi: 10.1016/j.celrep.2018.07.034.

-Targeting SHIP-1 in Myeloid Cells Enhances Trained Immunity and Boosts Response to Infection.

Saz-Leal P, Del Fresno C, Brandi P, Martínez-Cano S, Dungan OM, Chisholm JD, Kerr WG, Sancho D. Cell Rep. 2018 Oct 30;25(5):1118-1126. doi: 10.1016/j.celrep.2018.09.092. 


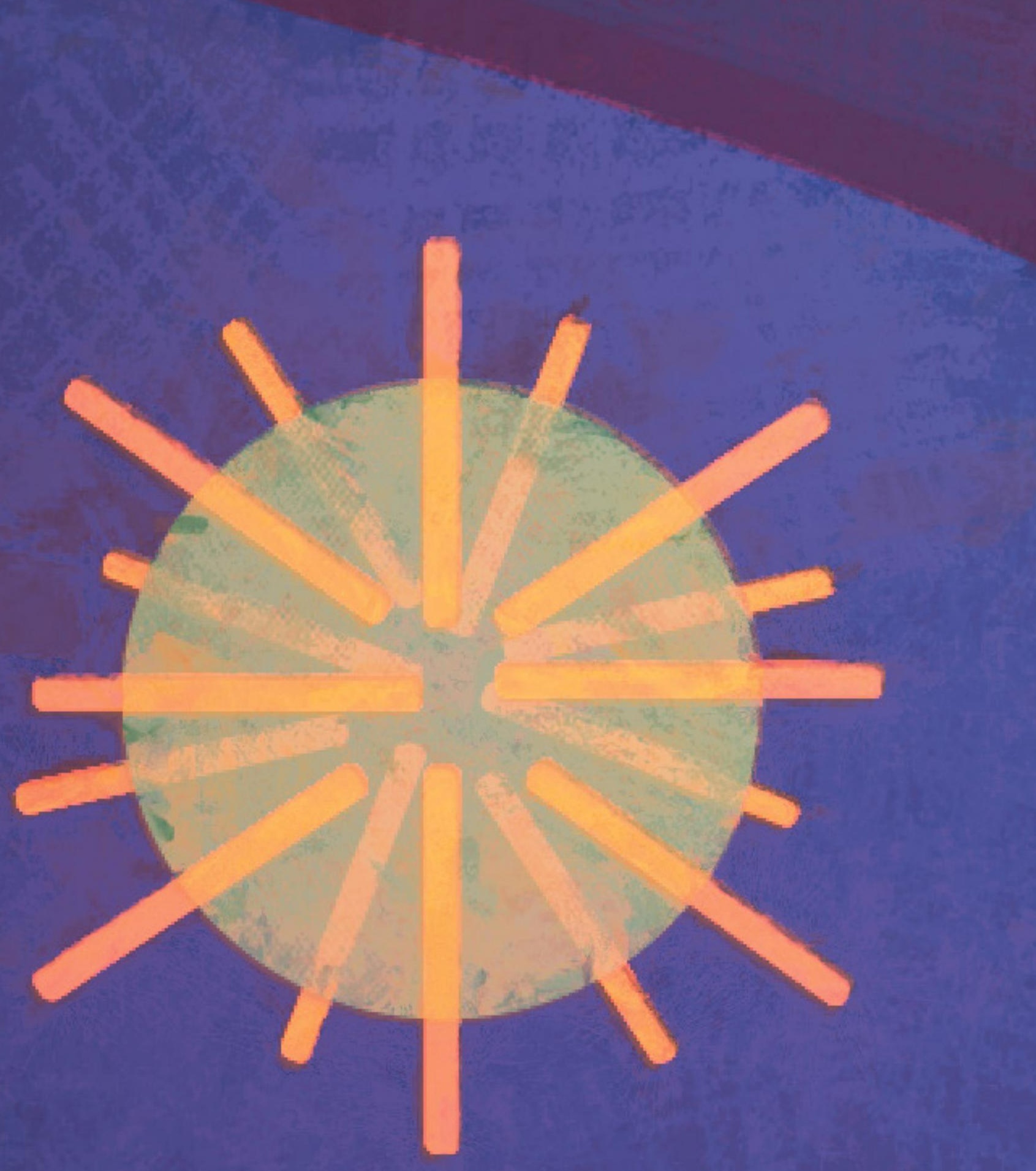


䅈

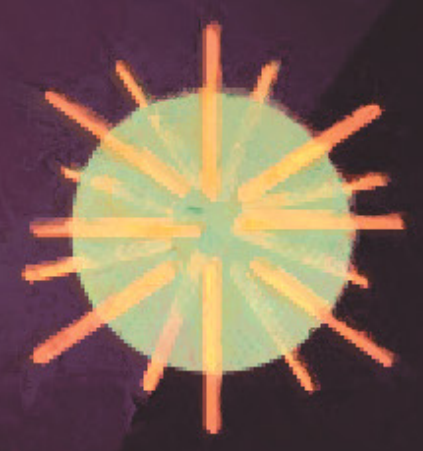

$$
x^{2} x^{2}
$$
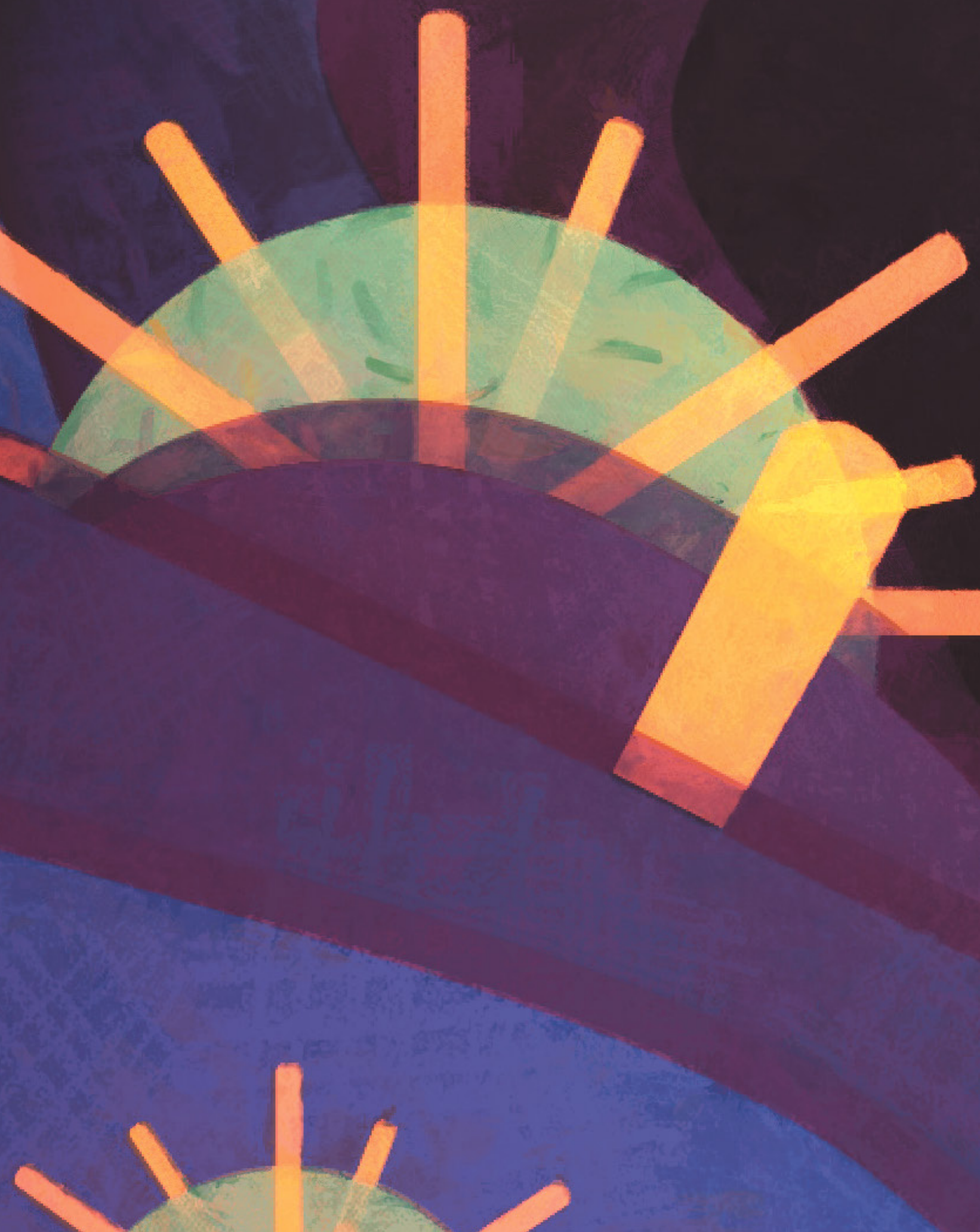


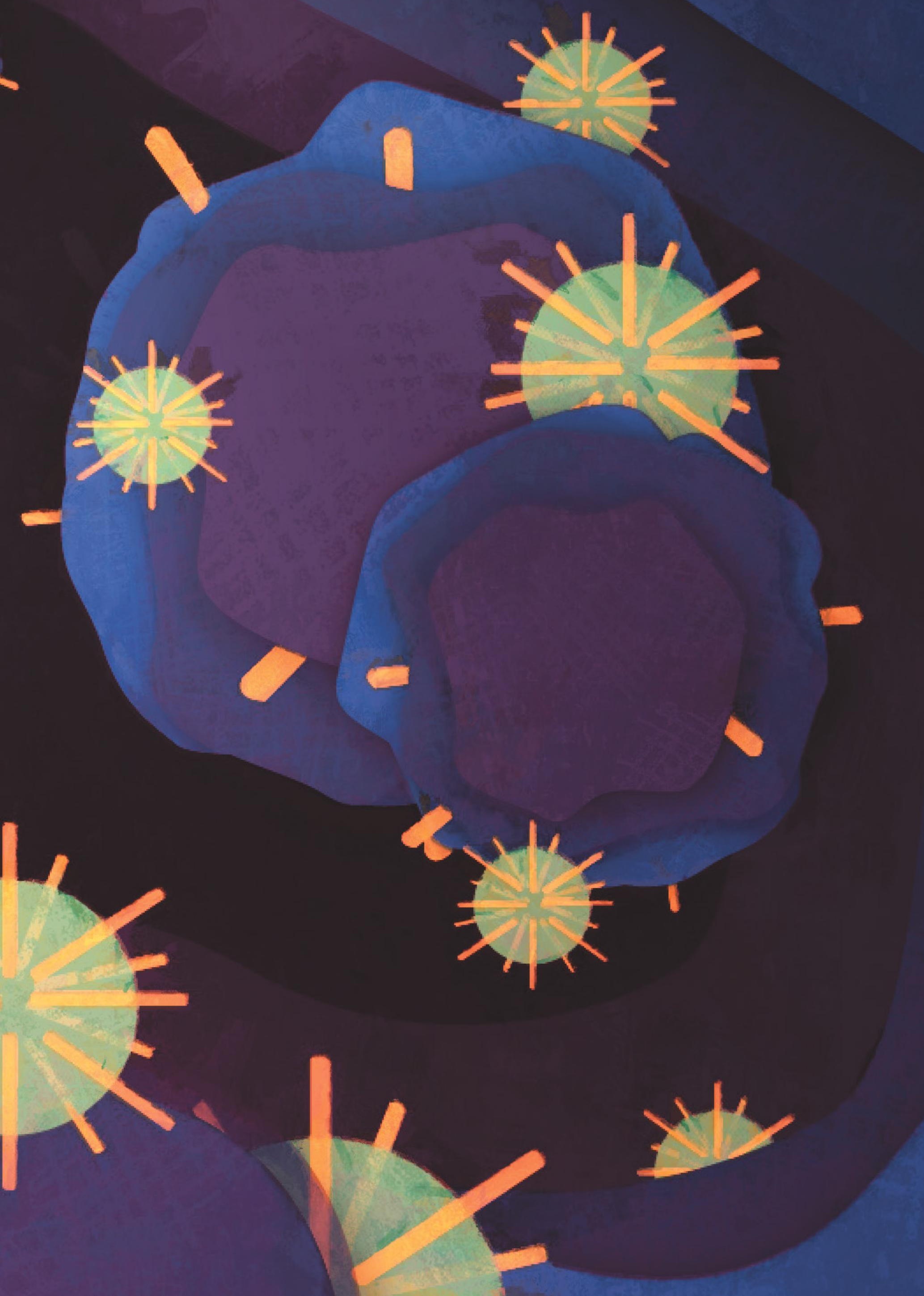


